\title{
Energy and Environmental Issues in Eastern Europe and Central Asia: An Annotated Guide to Information Resources
}

K. S. Gant

K. L. Kline

T. D. Ferguson

M. V. Lapsa 
This report has been reproduced from the best available copy.

Reports are available to the public from the following source.

National Technical Information Service

5285 Port Royal Road

Springfield, VA 22161

Telephone 703-605-6000 (1-800-553-6847)

TDD 703-487-4639

Fax 703-605-6900

E-mail orders@ntis.fedworld.gov

Web site http://www.ntis.gov/ordering.htm

Reports are available to U.S. Department of Energy (DOE) employees, DOE contractors, Energy Technology Data Exchange (ETDE) representatives, and International Nuclear Information System (INIS) representatives from the following source.

Office of Scientific and Technical Information

P.O. Box 62

Oak Ridge, TN 37831

Telephone 423-576-8401

Fax 423-576-5728

E-mail reports@adonis.osti.gov

Web site http://www.osti.gov/products/sources.html

Reports produced after January 1, 1996, are generally available via the DOE Information Bridge.

Web site $\mathrm{http}: / / \mathrm{www}$. doe.gov/bridge

This report was prepared as an account of work sponsored by an agency of the United States government. Neither the United States government nor any agency thereof, nor any of their employees, makes any warranty, express or implied, or assumes any legal liability or responsibility for the accuracy, completeness, or usefulness of any information, apparatus, product, or process disclosed, or represents that its use would not infringe privately owned rights. Reference herein to any specific commercial product, process, or service by trade name, trademark, manufacturer, or otherwise, does not necessarily constitute or imply its endorsement, recommendation, or favoring by the United States government or any agency thereof. The views and opinions of authors expressed herein do not necessarily state or reflect those of the United States government or any agency thereof. 


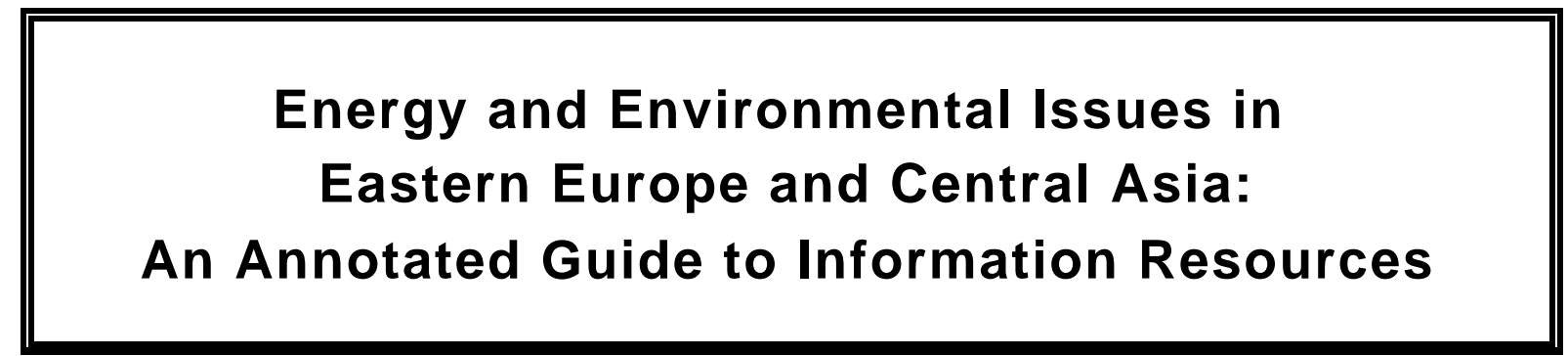

\author{
K. S. Gant \\ K. L. Kline \\ T. D. Ferguson \\ M. V. Lapsa
}

September 30, 2000

Prepared for

the U.S. Environmental Protection Agency under Contract Number 62XSY696

\title{
Prepared by
}

OAK RIDGE NATIONAL LABORATORY

Oak Ridge, Tennessee 37831-6285

managed by

UT-BATTELLE, LLC

for the

U.S. DEPARTMENT OF ENERGY

under contract DE-AC05-00OR22725 



\section{CONTENTS}

ACKNOWLEDGMENTS $\ldots \ldots \ldots \ldots \ldots \ldots \ldots \ldots \ldots \ldots \ldots \ldots \ldots \ldots \ldots$

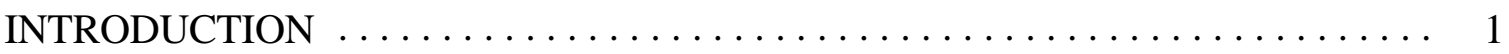

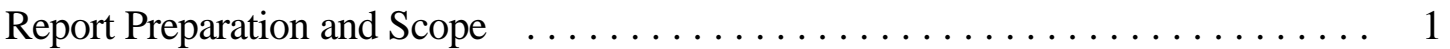

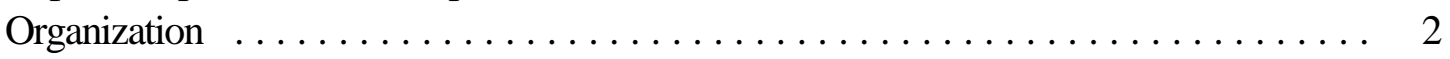

Understanding the Format for Citations $\ldots \ldots \ldots \ldots \ldots \ldots \ldots \ldots \ldots \ldots \ldots$

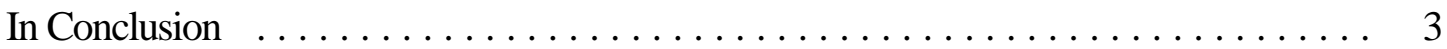

BIBLIOGRAPHICAL DATABASES AND SEARCH ENGINES $\ldots \ldots \ldots \ldots \ldots \ldots$

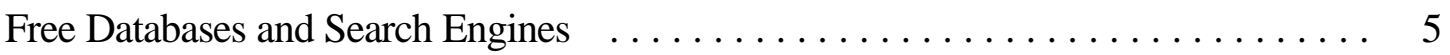

Fee-Based and Commercial Databases $\ldots \ldots \ldots \ldots \ldots \ldots \ldots \ldots \ldots \ldots \ldots \ldots$

RESOURCES BY GEOGRAPHIC AREA $\ldots \ldots \ldots \ldots \ldots \ldots \ldots \ldots \ldots \ldots \ldots \ldots$

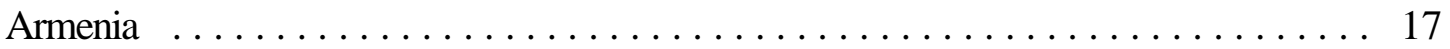

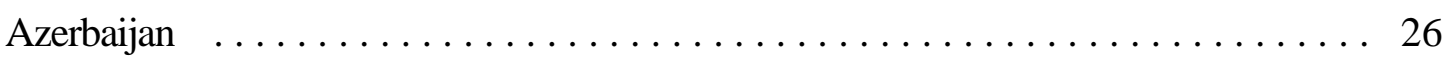

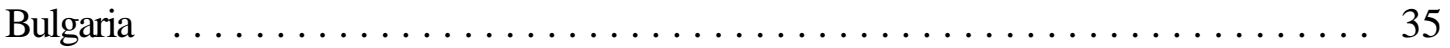

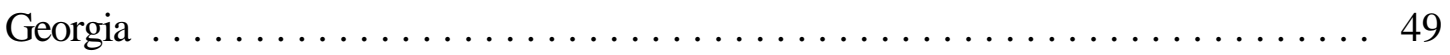

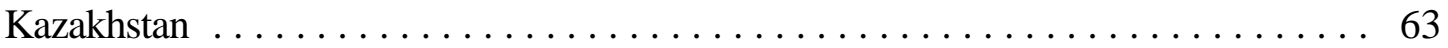

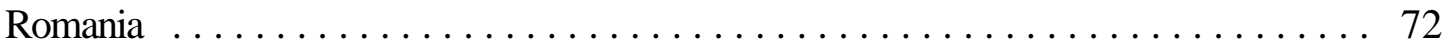

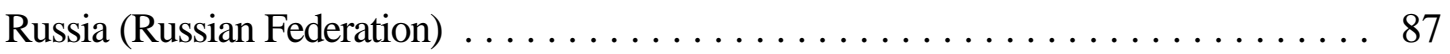

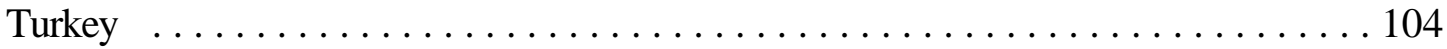

Ukraine . . . . . . . . . . . . . . . . . . . . . . . . . . 117

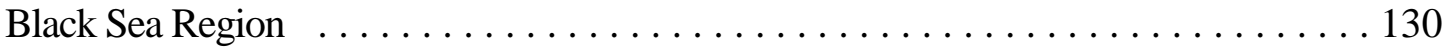

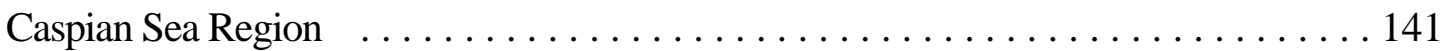





\section{ACKNOWLEDGMENTS}

The authors acknowledge and appreciate the invaluable contributions from these Oak Ridge National Laboratory colleagues:

- R. E. Conrad provided guidance with information searches and information on the bibliographic data bases and search engines discussed in the second section of document.

- $\quad$ R. B. Shelton and R. D. Perlack contributed technical review and guidance.

- C. I. Moser edited the document, working late to meet project deadlines. 


\section{INTRODUCTION}

"With so much information online, it is exceptionally easy to simply dive in and drown." - Alfred Glossbrenner

E nergy and environmental problems undermine the potential for sustained economic development and contribute to political and economic instability in the strategically important region surrounding the Caspian and Black Seas. Many organizations supporting efforts to resolve problems in this region have found that consensus building - $\mathrm{a}$ prerequisite for action - is a difficult process. Reaching agreement on priorities for investment, technical collaboration, and policy incentives depends upon informed decision-making by governments and local stakeholders. And while vast quantities of data and numerous analyses and reports are more accessible than ever, wading through the many potential sources in search of timely and relevant data is a formidable task.

To facilitate more successful data searches and retrieval, this document provides annotated references to over 200 specific information sources, and over twenty primary search engines and data retrieval services, that provide relevant and timely information related to the environment, energy, and economic development around the Caspian and Black Seas. This document is an advance copy of the content that Oak Ridge National Laboratory (ORNL) plans to transfer to the web in HTML format to facilitate interactive search and retrieval of information using standard web-browser software.

\section{REPORT PREPARATION AND SCOPE}

To compile this report, we reviewed more than 1000 documents and web sites during September 2000. The content, size, timeliness, and utility of the sites and reports varied greatly; and the number of sites offering information related to development issues in this region grows and changes constantly. Many sites, including Energy Information Administration pages, were well-maintained, updated regularly, and provided links to additional relevant resources. Other web sites, such as those sponsored by the World Bank and the Community Research and Development Information Service (CORDIS) offered powerful search engines capable of generating hundreds of links for a specific search request such as "Black Sea + environment." The World Bank site also offered a tool that allowed users to extract specific data and organize it to build custom tables. 
This report lists and annotates information resources; most were readily accessed on the Internet. Sites selected for annotation were considered to have useful information related to environmental, economic, and energy issues in selected countries of Eastern Europe and Central Asia. A few recent journal articles and books are included to provide an example of the information that can be found when using one of the many dedicated search engines linked to commercial and governmental databases (such as the energy databases sponsored by DOE or Cambridge Scientific Abstracts). Many search tools are free for public use. Others are feebased but can generally be accessed through institutional or public library services.

Given the dynamic nature of data sets accessible via the Internet and the large number of possible sources, this report is not exhaustive in scope. Rather, it provides an organized set of summaries for selected information sources that are within the reach of most interested parties.

\section{ORGANIZATION}

The information in this report is organized under two general categories: search engines and other information resources. The search engine section includes bibliographic and abstract search services as well as Internet home pages that offer large data sets and selection options related to nearly all the countries and topics of interest in the region. Over 20 search engine resources are annotated, falling into two subcategories:

- free, public web sites with powerful search capabilities for relevant links, data and reports; and

- $\quad$ subscription/fee-based (restricted) bibliographic search services for abstracts, journal articles, etc.

Other information resources are organized into chapters by geographic area:

- Countries

- Armenia

- Azerbaijan

- Bulgaria

- Georgia

- Kazakhstan

- Romania

- Russia (Russian Federation)

- Turkey

- Ukraine

- Regions

- Black Sea

- Caspian Sea 


\section{UNDERSTANDING THE FORMAT FOR CITATIONS}

Each Internet annotation follows a standard format (non-Internet resources may differ somewhat):

\section{Title (generally as noted at the top of the URL web site)}

Location (usually, the URL or web site address)

Date posted or last updated. ${ }^{1}$ Size, in number of pages. ${ }^{2}$ Maps? Tables? Useful links?

A brief description of content found at this site. To increase the value of the annotation, an example of relevant content is often included. Any quotations in this section are taken directly from the referenced site.

Key words: Geographic area (country name or region); topic areas (any combination of energy, environment, GHG/GCC, economics, oil/natural gas, institutional development, international agreements); source (institutional site sponsor/author)

The information presented in each citation was accurate at the time of preparation: September 15-27, 2000. It reflects an effort to present a synopsis of the information encountered in the referenced sites at that time. Inclusion in this report does not represent endorsement by DOE or its contractors. Because of the rapidly changing nature of the Internet, it is inevitable that some sources will change in format, content, or location over time.

\section{IN CONCLUSION}

How much information is available on the web? No one knows. Studies in late 1999 calculated that the World Wide Web held one billion distinct documents. ${ }^{3}$ By June 2000, a single search engine reported that it had access to over a billion pages, and total size was estimated to be about 500 billion pages of information. ${ }^{4}$ Internet traffic is doubling every 100 days. ${ }^{5}$

\footnotetext{
1 This information reflects the date (month and year) noted on the web page when we researched the site, September 2000. If no date was evident on the web page, but it pertained to other dated reports, we provide an estimated date (year only) based on the most recent such report.

${ }^{2}$ Since most material was viewed on-screen, an estimate is often provided here on the number of pages that would be generated if the content were to be printed. The actual number of pages will vary depending upon the fonts and formats of individual systems.

3 Reka Albert, Hawoong Jeong, and Albert-Laszlo Barabasi, "Diameter of the World Wide Web," Nature, Sept. 9, 1999, pp. 130-31; Rita Tehan, CRS Issues Brieffor Congress: RL30435: Internet and ECommerce Statistics: What They Mean and Where to Find Them on the Web, Feb. 17, 2000.

4 Danny Sullivan, “Invisible Web Gets Deeper," The Search Engine Report, online at http://www.searchenginewatch.com/reports/sizes.html, Aug. 2, 2000. Estimate based on Google's reported
} 
Neurologists have compared the web to a giant brain; and research by a team of Notre Dame physicists led the Congressional Research Service to conclude, "Thus, the Web seems to have taken on an organic life of its own.'

This document will allow users to identify sources for their specific needs more efficiently or to identify gaps in existing data that need more attention from the development community. The primary goal is to make it easier to access information that can contribute to improving the environmental health and social welfare around the Caspian and Black Seas. The authors also hope that it will enable users to dive into the ocean of Internet information without drowning.

If you have questions or comments about the report, please feel free to contact Kathy Gant (gantks@ornl.gov) or Keith Kline (klinekl@ornl.gov) at Oak Ridge National Laboratory, P.O. Box 2008, Oak Ridge, Tennessee, 37831.

size and Northern Light study on the "hidden web."

5 U.S. Department of Commerce, Secretariat for Electronic Commerce, "Building Out the Internet," Chapter 2 of Framework for Global Electronic Commerce, online at http://www.ecommerce.gov/ chapter2.htm, updated Apr. 16, 1998.

${ }^{6}$ Rita Tehan, CRS Issues Brieffor Congress: RL30435: Internet and E-Commerce Statistics: What They Mean and Where to Find Them on the Web, Feb. 17, 2000. 


\title{
BIBLIOGRAPHIC DATABASES AND SEARCH ENGINES
}

\author{
Numbers: \\ 10,000,000 web pages accessed by largest search engines in 1995; \\ 500,000,000 web pages accessed by largest search engines in 1999; \\ 1,060,000,000 web pages accessed by largest search engine, June 2000. \\ 1/500 of the estimated proportion of total information on the web is accessible \\ by the largest search engines. \\ - Information derived from Danny Sullivan, The Search Engine Report
}

S everal web sites provided powerful search engines and effective links to many other sources of information. Numerous bibliographic databases from the U.S. Department of Energy (DOE) and commercial vendors provide citations to timely and relevant environmental and energy literature. Some sources provide only abstracts, while others offer links to the full-text publications. A selection of these search tools is described.

\section{FREE DATABASES AND SEARCH ENGINES}

\section{ETDEWEB, Energy Technology Data Exchange World Energy Base}

http://www.etde.org/etdeweb/

1995 to present. 700,000 citations; 79,000 full-text publications; 3.5 million pages

The ETDEWEB includes information on the environmental impact of energy production and use, including climate change; energy R\&D; energy policy; nuclear, coal, hydrocarbon and renewable energy technologies; and much more. Access in the United States is free through the U.S. Department of Energy's Office of Scientific and Technical Information (OSTI), but users must register. The site contains links to full-text publications and includes ample coverage from international sources.

Key words: Armenia, Azerbaijan, Bulgaria, Georgia, Kazakhstan, Romania, Russian Federation, Turkey, Ukraine, Black Sea, Caspian Sea; energy, environment, GHG/GCC, economics, oil/natural gas, institutional development, international agreements; International Energy Agency (IEA) 


\section{Community Research \& Development Information Service (CORDIS) Home Page}

http://www.cordis.lu/en/home.html

September 2000. 1 page. Search engine

A user-friendly, interactive search engine, CORDIS can quickly find information from sources associated with the European Community, which is sponsoring many energy and environmental projects in Eastern Europe and Central Asia. When the user searches from the home page (box at top right), results are organized by categories such as related-topic web pages, recent news articles, partner web sites, publications, and projects. A search on "Black Sea Environment" generated 100 results, listed by date and category, including 26 topic-based web pages, 31 projects, 8 publications, and web sites for 12 partner organizations. Contact information is also provided. News sites are updated daily.

Key words: Armenia, Azerbaijan, Black Sea, Bulgaria, Caspian Sea, Georgia, Kazakhstan, Romania, Russia, Turkey, Ukraine; energy, environment, oil/natural gas, GHG/GCC, economics, international agreements, institutional development; European Union, CORDIS

\section{ENRIN, Environment and Natural Resource Information Network, Home} http://www.grida.no/enrin/index.htm

May 1999. Home page. Map, Links to more recent reports with data, graphs.

The home page for the Environment and Natural Resource Information Network in Central and Eastern Europe and Newly Independent States provides links to reports on 27 countries in the region, including 25 national State of Environment Reports, Urban Center Environmental Reports (Kiev, Tbilisi), national contacts, regional activities, publications and links to related sites including a similar regional web site presenting national biodiversity information from 22 Central and Eastern European countries/Newly Independent States.

Key words: Armenia, Azerbaijan, Bulgaria, Georgia, Kazakhstan, Romania, Russia, Turkey, Ukraine, Black Sea, Caspian Sea; economics, environment, energy, GHG/GCC, oil/natural gas, international agreements, institutional development; United Nations Environment Programme

\section{Information Bridge, U.S. Department of Energy}

http://www.osti.gov/bridge

1995 to present. 363,000 citations; 79,000 full-text publications

Reports from the U.S. Department of Energy (DOE), its contractors, other U.S. government agencies, professional societies, and the International Energy Agency are cited. The Information Bridge is a subset of the fee-based Energy Data Base, with the advantage of being free and 
containing some full-text publications. There is also a version, accessible to DOE and its contractors (http://www.osti.gov/doebridge), that includes additional citations to journal literature.

Key words: Armenia, Azerbaijan, Bulgaria, Georgia, Kazakhstan, Romania, Russian Federation, Turkey, Ukraine, Black Sea, Caspian Sea; energy, environment, GHG/GCC, economics, oil/natural gas, institutional development, international agreements; U.S. Department of Energy, U.S. government

\section{Alexander's Gas and Oil Connections News and Trends}

http://www.gasandoil.com/goc/news/welcome.html

1996 to present, news updated regularly. 1 page (home page). Links

A region of the world can be selected from this entry page. This selection reveal a set of links to recent articles dealing with oil- and gas-related topics affecting the selected region. Choosing the "History" link at the top of the page leads to an archive of news coverage on the global gas, oil, and power industry. The user can search the entire site or selected portions of the site with an internal search engine at http://www.gasandoil.com/goc/search/welcome.html .

Key words: Armenia, Azerbaijan, Bulgaria, Georgia, Kazakhstan, Romania, Russia, Turkey, Ukraine, Black Sea, Caspian Sea; oil/natural gas; Alexander's Gas and Oil Connections

\section{International Energy Agency Statistics}

http://www.iea.org/statist/index.htm

June 2000, updated regularly. 3 pages (home page). Links to statistical data

This site describes the data collected by the Energy Statistics Division of the International Energy Agency for member countries, including the monthly energy survey, monthly price statistics, monthly natural gas survey, and monthly oil survey. Results are available in PDF and Excel 97 format. The search capability provided can locate more limited data for non-member countries. Links to other energy data are also available.

Key words: Armenia, Azerbaijan, Bulgaria, Georgia, Kazakhstan, Romania, Russia, Turkey, Ukraine; energy, oil/natural gas, economics; International Energy Agency 


\section{REESWeb: Russian and East European Studies Internet Resources}

http://www.ucis.pitt.edu/reesweb/

November 1998. 2 pages (search engine). Links

The REESWeb is a comprehensive index of electronic resources on the Balkans, the Baltic states, the Caucusus, Central Asia, Central Europe, Eastern Europe, the Russian Federation, and the former Soviet Union. A separate search engine is available, and resources are listed by discipline and type. Some links are more recent than the date on the search page.

Key words: Caspian Sea, Armenia, Azerbaijan, Bulgaria, Kazakhstan, Romania, Russia, Ukraine; economics; University of Pittsburgh

\section{The Mandela Projects}

http://www.american.edu/projects/mandala/TED/

June 2000. 1 page (home page)

The Mandela Projects are a collection of cross-disciplinary efforts to examine the impact of globalization of peoples and people. Mandela serves as an umbrella organization for several related but different projects: the Trade Environment Database (TED), the Inventory of Conflict and Environments, Etown, and the Global Classroom. TED includes a collection of case studies, also published as an online journal (http://www.american.edu/projects/mandela/TED/class.all.htm). The TED database can be searched by country at http://147.9.202.41/ICE/FindCases TED.HTML . Among the case studies found were titles such as "Russian Air Pollution," "Illegal CFC Production in Russia," "The Bosporus and Central Asian Oil," and "Sturgeon, Caviar, and Loss."

Key words: Black Sea, Caspian Sea, Armenia, Azerbaijan, Bulgaria, Kazakhstan, Romania, Russia, Turkey, Ukraine; economics, environment; American University

\section{Black Sea Regional Energy Centre (BSREC)}

http://www.bsrec.bg/index.html

2000. 2 pages (home page). Links

This site is the home page of the Black Sea Regional Energy Centre, supported by the Synergy Programme of the European Union. Member countries include Albania, Armenia, Azerbaijan, Bulgaria, Georgia, Greece, Macedonia, Moldova, Romania, Russia, Turkey, and Ukraine. The site contains links to projects, energy reviews for most countries, news, and meetings. An internal search engine is found at http://www.bsrec.bg/ search/index.html. 
Key words: Armenia, Azerbaijan, Bulgaria, Georgia, Romania, Russia, Turkey, Ukraine, Black Sea; energy, international agreements; Black Sea Regional Energy Centre

\section{United Nations Sustainable Development National Information Web Site http://www.un.org/esa/agenda21/natlinfo/ \\ June 2000, updated regularly. 2 pages}

This is the United Nations" "System-Wide Web Site on National Implementation of the Rio Commitments." Sustainable development information by country is organized by topic: social, economic, natural resource, and institutional. A full-text search of two databases-(1) economic, social, and related fields or (2) Economic and Social Council only-is available at http://www.un.org/esa/search/.

Key words: Armenia, Bulgaria, Georgia, Kazakhstan, Romania, Russia, Turkey, Ukraine; environment, energy, economics, institutional development, international agreements; United Nations

\section{United Nations Framework Convention on Climate Change (UNFCCC) Country Web Site \\ http://www.unfccc.de/resource/country/index.html}

September 2000, updated regularly as information received from countries. Links

The United Nations' inventory of country profile information related the UNFCCC with a quick search function. Includes information such as if and/or when the country ratified the convention and the Kyoto Protocol and the country's point of contact. Contains links to national web sites on climate change and to HTML or PDF files of national communication papers submitted to the UN FCCC. Papers, when available, describe each country's environmental state in detail, including national policies, charts, maps, and tables on greenhouse gas emissions. No national papers are currently online for Turkey or Ukraine.

Key words: Armenia, Azerbaijan, Bulgaria, Georgia, Kazakhstan, Romania, Russia, Turkey, Ukraine; environment, GHG/GCC, energy, oil/natural gas; United Nations

\section{The World Bank Group}

http://www.worldbank.org/

September 2000, updated annually. 1 page (home page). Links

This site contains links to the World Development Indicators database and additional links to comprehensive sites containing data organized by country, site maps, contacts, and data 
partners. Search engine and specific data queries can be constructed. Access to maps and data is found at http://www.worldbank.org/data/ . Country data provides three years of data indicators on the people, environment, economy, technology and infrastructure, and trade and finance by country (over 200) or country group (Europe and Central Asia or Middle Income). Individual definitions are available for each indicator. Supports custom data queries that build tables based on 54 variables (e.g., $\mathrm{CO}_{2}$ emissions, energy use per capita, GNP, and hightechnology exports) and six years of generated data. There is an internal search engine at http://www.worldbank.org/search.htm .

Key words: Armenia, Azerbaijan, Bulgaria, Georgia, Kazakhstan, Romania, Russia, Turkey, Ukraine; environment, economics, energy; World Bank

\section{World Energy Council-Energy Data Centre}

http://www.worldenergy.org/wec-geis/edc/open.plx?file=default/default.htm

2000. 1 page (query page to database)

The Energy Data Centre is a repository of descriptive and statistical data collected by the World Energy Council. Data are gathered primarily from the survey of energy resources and national energy data profiles. Energy efficiency indicators are also available for 29 countries. Long-term projections for global energy sector development up to the year 2050 (WEC/IIASA Scenarios) and an analysis of energy efficiency policies (Energy Efficiency Policies and Indicators report of 1998) are included. At this time, the database can only be searched by country, a number of additional aggregations and views are planned.

Key words: Armenia, Azerbaijan, Bulgaria, Georgia, Kazakhstan, Romania, Russia, Turkey, Ukraine; energy; World Energy Council

\section{The World Factbook, Central Intelligence Agency (CIA)}

http://www.cia.gov/cia/publications/factbook/index.html

2000. 1 page (home page). Links

Data is organized by country. Users can choose a complete country listing and view data organized by chapters on geography, people, government, economy, communications, transportation, military, and transnational issues. Information can also be reviewed and compared by specific topic using the "field listing" link, with categories such as environmental treaties, environmental issues, pipelines, international disputes, and various electricity statistics. The CIA 2000 Maps and Publications link lists all unclassified maps available to the public for purchase. 
Key words: Armenia, Azerbaijan, Bulgaria, Georgia, Kazakhstan, Romania, Russia, Turkey, Ukraine, Black Sea, Caspian Sea; energy, environment, economics, oil/natural gas, institutional development, international agreements; Central Intelligence Agency, U.S. government

\section{Energy Information Administration Country Analysis Briefs}

http://www.eia.doe.gov/emeu/cabs/contents.html

2000. 1 page (home page). Links

Main categories for data links include petroleum, natural gas, coal, nuclear, electricity, renewables, alternate fuels, international, environment, forecasts, and special regional studies, including Eastern Europe and Russia. The timeliness and level of detail for specific statistics can vary by country, but was often as recent as anything encountered on the web. Search capabilities by country and topic, and from within country pages. Many additional links are provided.

Key words: Armenia, Azerbaijan, Bulgaria, Georgia, Kazakhstan, Romania, Russian Federation, Turkey, Ukraine, Black Sea, Caspian Sea; energy, environment, GHG/GCC, economics, oil/natural gas, institutional development, international agreements; Energy Information Administration, U.S. government

\section{World Resources 1996-97}

http://data.wri.org:1996/

1997. 1 page (query page)

This page allows user to query the data set on which the World Resources 1996-1997 report was based. Users can customize their queries of World Resources 1996-1997 data tables by selecting variables and countries of interest; these are then displayed by the system in table format. A data query system for World Resources 1998-1999 was not encountered online.

Key words: Armenia, Azerbaijan, Bulgaria, Georgia, Kazakhstan, Romania, Russia, Turkey, Ukraine; economics, environment, energy, GHG/GCC, oil/natural gas, international agreements; World Resources Institute

\section{FEE-BASED AND COMMERCIAL DATABASES}

Many large commercial and U.S. government databases are available through subscription services for a fee. They can be accessed through academic institutions, libraries, or vendors such as Dialog, Datastar, and Cambridge Scientific Abstracts. These databases index journal 
articles, books, reports, and conference proceedings, many of which will not be located through free Internet search engines. A sampling of fee-based databases is described here.

\section{The Energy Science and Technology Database (EDB), U.S. Department of Energy (fee) \\ http://www.osti.gov/products/eionline.html \\ 1974 to present. 3.9 million records. No full-text links \\ Accessed by subscription through vendors such as NTIS \\ (http://www.ntis.gov/databases/engsci.htm), the Dialog Corporation \\ (http://www.dialogweb.com), or Silverplatter (http://www.silverplatter.com).}

Popularly referred to as the Energy Database, or EDB, this site claims through the site banner to be the "World's Most Comprehensive Collection of Energy, Science, and Technology Information." The database contains information from the U.S. Department of Energy, its contractors, other government agencies, professional societies, the International Energy Agency (IEA), and the International Atomic Energy Agency's International Nuclear Information System (INIS) pertaining to basic and applied scientific and technical research literature. The database contains citations and abstracts published worldwide regarding nuclear, coal, and global climate change; but full-text links are not offered.

Key words: Armenia, Azerbaijan, Bulgaria, Georgia, Kazakhstan, Romania, Russia, Turkey, Ukraine, Black Sea, Caspian Sea; energy, environment, GHG/GCC, economics, oil/natural gas, institutional development, international agreements; U.S. Department of Energy

\section{National Trade Data Bank (NTDB) and the International Trade Library, U.S. Department of Commerce (fee)}

http://www.stat-usa.gov/

Current economic and trade information, available by subscription from STAT-USA

"A one-stop source for export promotion and international market reports collected by more than 40 U.S. government agencies," these two databases from the U.S. Department of Commerce are good sources for trade, economic, and social data. The NTDB provides access to country commercial guides, market research, and U.S. import/export statistics. The International Trade library is a comprehensive collection of over 40,000 documents related to international trade. All are full-text searchable, as well as key-word searchable by country or product.

Key words: Armenia, Azerbaijan, Bulgaria, Georgia, Kazakhstan, Romania, Russia, Turkey, Ukraine, Black Sea, Caspian Sea; energy, environment, economics, oil/natural gas, institutional development, international agreements; U.S. Department of Commerce 


\section{Environmental Sciences \& Pollution Management Collection, CSA (fee)}

http://www.csa.com/

1990 to the present. Over one million records.

The full collection is accessed through subscription with Cambridge Scientific Abstracts (CSA); portions also available from other vendors such as the Dialog Corporation (http://www.dialogweb.com) and Datastar (http://www.datastarweb.com).

The Environmental Sciences and Pollution Management collection indexes world literature covering all areas of air, land, water, and noise pollution as well as bacteriology, ecology, toxicology, risk assessment, environmental engineering, environmental biotechnology, waste management, and water resources. Environmental policy and regulations are given significant coverage, as are U.S. environmental impact statements. There are 14 separate databases including Ecology Abstracts, Pollution Abstracts, and Water Resources Abstracts. Coverage varies for each database, with about half covering the 1980s to the present and others covering about 1990 to present. Over a million bibliographic records; $90 \%$ include abstracts, but direct access to full-text is not offered.

Key words: Armenia, Azerbaijan, Bulgaria, Georgia, Kazakhstan, Romania, Russia, Turkey, Ukraine, Black Sea, Caspian Sea; energy, environment, GHG/GCC, economics, oil/natural gas, institutional development, international agreements; Cambridge Scientific Abstracts

\section{Aquatic Sciences and Fisheries Abstracts Series, Cambridge Scientific Abstracts (fee)}

http://www.csa.com/

1980 to the present. Over 700,000 records; about 3,700 added each month

Accessed through subscription from vendors such as Cambridge Scientific Abstracts or the Dialog Corporation (http://www.dialogweb.com).

This is a collection of five databases focusing on worldwide aquatic sciences literature: biological sciences and living resources, ocean technology, policy and non-living resources, aquatic pollution and environmental quality, aquaculture abstracts, and marine biotechnology abstracts. Coverage varies, with some covering literature back as far as 1978 and others beginning with the late 1980s or early 1990s.

Key words: Armenia, Azerbaijan, Bulgaria, Georgia, Kazakhstan, Romania, Russia, Turkey, Ukraine, Black Sea, Caspian Sea; energy, environment, GHG/GCC, economics, oil/natural gas, institutional development, international agreements; Cambridge Scientific Abstracts 
GEOBASE, Dialogweb (fee)

http://www.dialogweb.com

1980 to the present. 1 million records; 6,000 new records each month

Accessed by subscription with vendors, such as the Dialog Corporation or Elsevier

(http://www.elsevier.com)

GEOBASE provides bibliographic information and abstracts for human and physical geography, ecology, geology, oceanography, geomechanics, and development studies. The database offers current coverage of over 1,700 scientific and technical periodicals and archival coverage of several thousand additional titles. GEOBASE contains nearly a million records dated since 1980, with 72,000 records added annually. GEOBASE includes non-English and other less readily available publications. Over 2,000 books, monographs, conference proceedings, and reports are also included. A search of GEOBASE through Dialog, using the keywords "Black Sea" or "Caspian Sea," produced 660 hits for 1990 through September 2000.

Key words: Armenia, Azerbaijan, Bulgaria, Georgia, Kazakhstan, Romania, Russia, Turkey, Ukraine, Black Sea, Caspian Sea; energy, environment, GHG/GCC, economics, oil/natural gas, institutional development, international agreements; Dialog Corporation

\section{Science Citation Index Expanded, Institute for Scientific Information (fee)}

http://www.isinet.com/isi/products/citation/sci

1945 to the present. Over 18.5 million records; available through subscription from the Institute for Scientific Information (from 1945 to the present), or it can be accessed through online vendors such as the Dialog Corporation (http://www.dialogweb.com), Datastar (http://www.datastarweb.com), and Science and Technology Network (STN) (http://www.cas.org/), from 1974 to the present

Science Citation Index includes an extensive set of records and abstracts from sources worldwide. For example, a search of the database using the keywords "Black Sea" and "Caspian Sea" for the years 1990 to September 2000 generated a list of approximately 1,700 articles.

Key words: Armenia, Azerbaijan, Bulgaria, Georgia, Kazakhstan, Romania, Russia, Turkey, Ukraine, Black Sea, Caspian Sea; energy, environment, GHG/GCC, economics, oil/natural gas, black sea issues, institutional development, international agreements; Institute for Scientific Information 


\section{PASCAL, Institut de I'Information Scientifique et Technique (INIST) (fee)}

http://www.dialogweb.com

1973 to the present. Over 13 million records. Accessed by subscription through the Dialog Corporation and various European database vendors.

Produced by the Institut de l'Information Scientifique et Technique (INIST) of the French National Research Council (CNRS), PASCAL is a multidisciplinary index/abstract to the world's scientific and technical literature. Titles are in English and French, but most abstracts are in French. This database provides good coverage of French literature, but $63 \%$ of the publications covered are in English and 10\% are Russian. A search of PASCAL through Dialog, using the keywords "Black Sea" or "Caspian Sea" produced 1,085 hits for the years 1990 to September 2000.

Key words: Armenia, Azerbaijan, Bulgaria, Georgia, Kazakhstan, Romania, Russia, Turkey, Ukraine, Black Sea, Caspian Sea; energy, environment, GHG/GCC, economics, oil/natural gas, institutional development, international agreements; Dialog Corporation

\section{Chemical Abstracts Selects--CAS (fee)}

http://www.cas.org

1974 to the present. Home page with links. Over 16 million document records; database access by paid subscription.

Chemical Abstracts Service and Registry home page, with links to several other database collections including the Science and Technology Network (STN) (http://stnweb.cas.org/). STN provides access to more than 200 databases of evaluated information in science and technology, with topics including energy, environment, government regulations, and petroleum. Its purpose is to meet the information needs of scientists, engineers, and researchers throughout the world.

Key words: Armenia, Azerbaijan, Bulgaria, Georgia, Kazakhstan, Romania, Russia, Turkey, Ukraine, Black Sea, Caspian Sea; economics, environment, energy, GHG/GCC, oil/natural gas, international agreements; Chemical Abstracts Service 


\section{INFORMATION RESOURCES BY GEOGRAPHIC AREA}

"A wealth of information creates a poverty of attention and a need to allocate that attention efficiently among the overabundance of information sources that might consume it." - Herbert Simon

$\mathrm{T}$ he remainder of this report provides annotations for information resources organized by a selected set of countries (Armenia, Azerbaijan, Bulgaria, Georgia, Kazakhstan, Romania, Russia, Turkey, Ukraine) and regions (Black Sea, Caspian Sea). Under each country, the resources are listed alphabetically by URL. If you have Internet access and a browser installed on your computer, you should be able to click on the URL (second line of each citation) and go directly to a chosen web site for further information. In the future, ORNL plans to organize this material using both geographic area and topics [economics, environment, energy, greenhouse gases/global climate change (GHG/GCC), oil/ natural gas, international agreements, and institutional development] from the "key words" at the end of each citation to facilitate fast, custom searches for information.

In order to prepare a complete list of resources by geographic area in this version of the report, a single citation is repeated under each country for which it offers relevant information.

\section{ARMENIA}

\section{Summit Declaration on Black Sea Economic Cooperation http://inter.mfa.gov.tr/grupa/af/Bsec7.HTM \\ June 1992. 2 pages. Narrative}

This site contains the text of the summit declaration at Istanbul, June 25, 1992, agreed to by the heads of state or governments of Albania, Armenia, Azerbaijan, Bulgaria, Georgia, Greece, Moldova, Romania, Russia, Turkey, and Ukraine. In the text, the parties state their intention to act to improve the environment and promote economic cooperation in the region.

Key words: Armenia, Azerbaijan, Bulgaria, Georgia, Romania, Russia, Turkey, Ukraine, Black Sea; economics, international agreements; Ministry of Foreign Affairs (Republic of Turkey) 


\section{Armenia and Nuclear Power}

http://www.american.edu/projects/mandala/TED/armenia.htm

1996. 8 pages. Narrative

This paper discusses Armenia's energy shortages and the decision, in June 1995, to reopen an aging Russian-built nuclear power plant closed after a 1988 earthquake. Armenia's war with Azerbaijan, difficult relations with Iran and Turkey, and uncertain gas supply through Georgian pipelines has kept the country in an energy crisis since independence from the Soviet Union.

Key words: Armenia; energy, environment; American University

\section{Caspian Oil and Political Implications}

http://www.american.edu/projects/mandala/TED/caspoil.htm

1998. 9 pages. Narrative

Although once thought minimal, Caspian oil reserves are now considered more plentiful than Persian Gulf oil. This paper discusses the various claims on Caspian oil, and the political complications of various pipeline routes from the area. Tensions between Armenia and Azerbaijan threaten the shortest route between Baku and Turkey. Once the oil reaches the Black Sea, the most viable option is to ship it through the Bosporus. This route, however, has environmental implications because there are frequent oil leaks from tankers working their way through the narrow straits

Key words: Armenia, Azerbaijan, Russia, Georgia, Turkey, Black Sea, Caspian Sea; oil/natural gas, environment; American University

\section{Black Sea Energy Review, Armenia}

http://www.bsrec.bg/armenia/armenia.html

September 1996. 2 pages (table of contents). Links to sections of report

The review provides up-to-date information and a profile of the energy sector of the Republic of Armenia with emphasis on the economic and institutional aspects. This energy review includes a map and interview. The report includes energy balance data, macroeconomic profile data, energy sector organization, energy pricing, energy legislation, economic legislation, financial sector, market reforms, investment opportunities, and a energy directory.

Key words: Armenia; energy, environment, natural gas/oil, GHG/GCC, economics; European Commission, Black Sea Regional Energy Centre. 


\section{The World Factbook-Armenia}

http://www.cia.gov/cia/publications/factbook/geos/am.html

January 2000. 8 pages. Map, data

Site contains an assortment of data about Armenia under the general topics of geography, people, government, economy, communications, transportation, military, and transnational issues. Site includes some information on the economy and electrical production and use, environment, and environmental agreements.

Key words: Armenia; economics, environment, energy, international agreements; Central Intelligence Agency, U.S. government

\section{OPET (Organizations for the Promotion of Energy Technologies) Home Page} http://www.cordis.lu/opet/home.html

December 1999. 2 pages. Links to over 80 energy-related web sites worldwide

The OPET Network "aims to promote the results of new energy technologies and their introduction in society in order to improve energy efficiency and broaden the use of renewable energy sources." Links to related sites include European Commission projects, Energy/Environment Research Centers, Energy Trade Associations, publications, events, success stories, and directories. One FEMOPET project focused on the Black Sea Region from 1998 to 2000 (Bulgaria/Romania). This was followed by the Black Sea Region OPET Associate Project (2000-2002, Russia, Turkey, Ukraine). Both projects, in conjunction with the Black Sea Regional Energy Centre, aimed to promote innovative renewable and conservation energy technologies.

Key words: Armenia, Azerbaijan, Black Sea, Bulgaria, Caspian Sea, Romania, Russia, Turkey, Ukraine; energy, environment, oil/natural gas, GHG/GCC, economics, international agreements, institutional development; European Commission Thermie Program

\section{International Data: Armenia}

http://www.eia.doe.gov/emeu/international/armenia.html

January 2000. 1 page. Links

Site contains links to spreadsheet energy and energy-related data for 1992-98, reported by fuel category, and a country energy balance. Links are provided to other reports.

Key words: Armenia; energy, oil/gas, GHG/GCC; Energy Information Administration, U.S. government 


\section{Armenia}

http://www-esd.worldbank.org/ecssd/envcopg/esarm.html

August 1998. 3 pages. Map, narrative, data

The site contains a country map, data on land and water use, natural resources, biodiversity, energy efficiency, $\mathrm{CO}_{2}$ emissions, and treaty participation. The key environmental problems are briefly described. Current World Bank environment and rural development projects are listed, along with country and World Bank contacts.

Key words: Armenia; environment, GHG/GCC; World Bank

\section{Biodiversity of Armenia}

http://www.grida.no/enrin/biodiv/biodiv/national/armenia/

2000. 1 page (home page). Links

This page contains links to sections of the biodiversity report. The linked material includes descriptions of the many species of plants and animals and the current threats to those species. The strategy for protecting the ecology is also discussed.

Key words: Armenia; environment, institutional development, international agreement; Ministry of Nature Protection (Armenia)

\section{Armenia ENRIN Home}

http://www.grida.no/enrin/htmls/armenia/index.htm

October 1998. Home page, map, links.

At this site, reports on the State of Environment 1998 (http://www.grida.no/enrin/htmls/ armenia/soe armenia/soeeng.htm) and Environmental Information Systems (http://www.grida.no/enrin/htmls/armenia/arm assm.htm) are available for Armenia. The Environment and Natural Resource Information Network (ENRIN) in Central and Eastern Europe and Newly Independent States (CEE/NIS) home page provides direct links to reports on 27 countries in the region, including 25 national State of Environment Reports, 22 national reports on biodiversity, national contacts, regional activities, publications and other links.

Key words: Armenia; environment, energy, institutional development; UNEP-GRID 


\section{Key Energy Indicators for Armenia}

http://www.iea.org/stats/files/selstats/keyindic/nmc/armenia.htm

1997. 2 pages. Data, chart, map, links

Key energy indicators are presented in a table. Data include population, GDP, energy supply, and electricity consumption. Energy supply and electricity consumption are also shown per capita and per GDP. The chart shows the portion of total energy production by fuel. Links to more detailed information are provided.

Key words: Armenia; energy, economics; International Energy Agency

\section{Facts and Figures: Environmental Data Tables}

http://www.igc.org/wri/facts/data-tables.html

March 2000. 1 page. Links

This page presents links to data tables taken from World Resources 1998-1999. These tables (in PDF format) contain information on atmosphere and climate, biodiversity, economic indicators, energy and materials, food and agriculture, forests and land cover, freshwater, health, oceans and fisheries, population and human development, and urban data.

Key words: Armenia, Azerbaijan, Bulgaria, Georgia, Kazakhstan, Romania, Russia, Turkey, Ukraine; economics, environment, energy, GHG/GCC, gas/oil, international agreements; World Resources Institute

\section{Sustainable Development: Information on Armenia}

http://www.un.org/esa/agenda21/natlinfo/countr/armenia/index.htm

2000. 1 page. Links

This page provides links to information on four aspects of sustainable development in Armenia: social, natural resource, economic, and institutional. A series of indicators (statistical data) are provided for each aspect. More detail is provided for identified subtopics under each indicator.

Key words: Armenia; environment, GHG/GCC, institutional development; United Nations 


\section{United Nations Development Programme (UNDP) Global Environment Facility (GEF)}

http://www.undp.org/gef/portf/climeur.htm

September 2000, updated regularly. 7 pages. Table

UNDP-GEF maintains a current online portfolio of projects by country. Separate tables exist for different GEF focal areas: climate, biodiversity, international waters, and ozone depletion. Included in the portfolio tables are the country name, region, project name, project description, GEF allocation (in millions), and project type (the types are labeled as PDF- Project Development Facility; EA—Enabling Activities; PRIF—Pre-Investment Feasibility Study; FP-Full Project; MSP-Medium-size projects). The portfolio includes regional projects for both Black and Caspian Sea, as well as national projects in nearly every country of the region.

Key words: Armenia, Azerbaijan, Bulgaria, Georgia, Kazakhstan, Romania, Russia, Turkey, Ukraine, Black Sea, Caspian Sea; environment, GHG/GCC, institutional development; United Nations Development Programme

\section{United Nations Development Programme (UNDP) National Human Development Reports http://www.undp.org/hdro/table.htm}

August 2000, updated frequently. 5 pages. Table of available reports, links

More than 100 countries have published National Human Development Reports with UNDP support. By providing comprehensive indicators, the reports help to monitor progress and setbacks in human development and poverty at the national-level. The annual summary report for 2000 is also available online at http://www.undp.org/hdr2000/english/HDR2000.html. The 2000 Human Development Report includes a summary of national indicators such as energy use, growing urbanization, profile of environmental degradation, and access to information and communications. Each report also focuses on a highly topical theme in the current development debate, providing path-breaking analysis and policy recommendations. Individual country reports for some years are available online.

Key words: Armenia, Azerbaijan, Bulgaria, Georgia, Kazakhstan, Romania, Russia, Turkey, Ukraine; energy, environment, GHG/GCC, economics; United Nations Development Programme 


\section{The Ozone Secretariat, UNEP-Nairobi, Kenya}

http://www.unep.ch/ozone/

August 2000. 1 page (home page). Links

Site contains a description of the activities of the Ozone Secretariat, with links to treaties, reports, addresses, and other sites. One of the linked sites (http://www.unep.ch/ozone/ratif.htm) shows each country's signature and ratification status on agreements on the protection of the stratospheric ozone layer.

Key words: Armenia, Azerbaijan, Bulgaria, Georgia, Kazakhstan, Romania, Russia, Turkey, Ukraine; environment, GHG/GCC, international agreements; United Nations Environment Programme

\section{Armenia}

http://www.unfccc.de/resource/country/armenia.html

September 2000.1 page. Data, links

This United Nations web page shows Armenia's status on signature and ratification of the United Nations Framework Convention and the Kyoto Protocol. Armenia has ratified the Framework Convention. Links are provided to the first national communication (status report) and points of contact.

Key words: Armenia; environment, GHG/GCC; United Nations Framework Convention on Climate Change

\section{U.S. Agency for International Development, Armenia Home Page}

http://www.usaid.gov/am

August 2000, updated regularly. 1 page. Links

Set of links to the U.S. Agency for International Development's programs in Armenia. News reports, program overview, funding graphs and tables, implementation partners, other donor activities, success stories and accomplishments are provided for each program, including Energy Sector Reform http://www.usaid.gov/am/energy.html (privatization, diversification, environmental and economic efficiency) and Waste Management http://www.usaid.gov/am/water.html (policies, water quality monitoring and market-based services).

Key words: Armenia; energy, economics; U.S. Agency for International Development, U.S. government 


\title{
USAID Armenia Program Overview
}

http://www.usaid.gov/am/program.html

August 2000, updated annually. 4 pages. Narrative, links

An overview of U.S. assistance priorities and programs in Armenia. Links are provided to recent progress reports (31 pages, "R4"document), the U.S. Agency for International Development (USAID)/Armenia Strategic Plan for 1999-2003, and the most recent congressional presentation (RTF document format, 25 pages). USAID's strategy supports institutional and policy reforms and pilot activities related to private-sector development, energy and water sectors, social services, and other projects.

Key words: Armenia; energy, economics; U.S. Agency for International Development, U.S. government

\author{
U.S. Agency for International Development, USAID Country Profile, Armenia \\ http://www.usaid.gov/countries/am/am.html \\ January 1997. 2 pages. Narrative, data
}

Statistical summary on Armenia and an overview of the U.S. Agency for International Development's strategic objectives to assist the nation with its (1) democratic transition, (2) economic restructuring, and (3) social stabilization (emergency humanitarian aid, primarily food and fuel).

Key words: Armenia; economics; U.S. government, U.S. Agency for International Development, U.S. government

\section{Armenia-Energy Information}

http://www.worldenergy.org/wec-geis/members only/registered/open.plx?file=edc/default/ country/ARM.stm

1998. 1 page. Narrative

This site contains a brief description of Armenia's nuclear power resources (a 376-MWe reactor came back into operation in 1996) and a review of the control of the electrical industry. The electricity industry is still state-owned, but privatization of the main distribution company is to start in 2000.

Key words: Armenia; energy; World Energy Council 
World Energy Council-Survey of Energy Resources, 1998

http://www.worldenergy.org/wec-geis/publications/open.plx?file=default/current ser.htm

1998. 1 page. Table of contents, with links to each section

The 1998 survey provides an updated review of world energy resources. It reports the adequacy of the world's total energy resource base and highlights, to an increasing degree, the environmental advantages and disadvantages of each fuel, with a particular and growing emphasis on $\mathrm{CO}_{2}$ and other greenhouse gas emissions. The dominance of the main commercial fossil fuels - oil, gas, and coal — is expected to continue for the foreseeable future, with the share of natural gas increasing. Several renewable energies (e.g., solar, wind) seem to be set on the path of rapid growth and declining cost. This should see them securing competitive advantage, initially in key niche areas, before broadening in role and importance. Site includes data tables with country information.

Key words: Armenia, Azerbaijan, Bulgaria, Georgia, Kazakhstan, Romania, Russia, Turkey, Ukraine; energy, environment, gas/oil, GHG/GCC; World Energy Council

\section{Armenia at a Glance: Agriculture, Natural Resources, and Environment http://www.wri.org/facts/cs-pdf/armenia.pdf \\ 1997. 4 pages. Data, charts (PDF format)}

This World Resources Institute fact sheet highlights data on Armenia's economic and social context; agricultural, forest, freshwater, marine, coastal, and biodiversity resources; energy and mineral resources; and involvement in international agreements. The data for these fact sheets came from the World Resources 1996-97 database, and the project was funded by the Agriculture and Natural Resource Department of the World Bank.

Key words: Armenia; economics, environment, energy, international agreements; World Resources Institute

\section{Black Sea Energy Survey}

International Energy Agency

June 2000. 256 pages

This study of the Black Sea region as a whole looks at its energy needs and how future oil and gas transport in the region could develop. It reviews the energy policies and sectors of seven countries with diverse energy situations. Azerbaijan is a major oil producer and exporter; Armenia and Georgia are energy-poor; Bulgaria and Romania are EU accession candidates which must restructure their domestic oil and coal industries; Greece and Turkey are IEA member states. This study covers energy strategies, institutions, and restructuring, as well as 
recent and projected energy trends in these countries. The book analyzes the reforms that are still needed to attract significant investment, both in domestic energy projects and in regional energy trade. A table of contents, sample material, and ordering information are found at http://www.iea.org/pubs/studies/files/blacksea/index.htm .

Key words: Black Sea, Armenia, Azerbaijan, Bulgaria, Georgia, Romania, Turkey; energy, oil/natural gas, economics; International Energy Agency

World Resources, 1998-1999

World Resources Institute, United Nations Environment Programme, United Nations Development Programme, World Bank, Oxford University Press (USA) 1998. 384 pages. Database is also available on CD-ROM and diskette

This biennial report looks at the current state of the environment as it relates to population and human well-being, consumption and waste, and resources at risk. The book also contains country data from 157 countries and new information on poverty, inequality, and food security.

Key words: Armenia, Azerbaijan, Bulgaria, Georgia, Kazakhstan, Romania, Russia, Turkey, Ukraine; economics, environment, energy, GHG/GCC, gas/oil, international agreements; World Resources Institute

\section{AZERBAIJAN}

\section{Water Features and Water Issues: Caspian Sea} http://eol.jsc.nasa.gov/newsletter/html Mir/caspian.html June 2000. 5 pages. Narrative, photographs

This site contains NASA-Mir photographs of the flooded coastal regions of the Caspian Sea. The Caspian sea level has been rapidly rising (about 1.5-2 m) for the past several years. Coastal regions, including infrastructures supporting the large oil industry, have been flooded. One photograph shows the largest oil slick photographed from space, off the shore of Azerbaijan.

Key words: Caspian Sea, Azerbaijan; environment; Jet Propulsion Laboratory

\section{Summit Declaration on Black Sea Economic Cooperation}

http://inter.mfa.gov.tr/grupa/af/Bsec7.HTM

June 1992. 2 pages. Narrative 
This site contains the text of the summit declaration at Istanbul, June 25, 1992, agreed to by the heads of state or governments of Albania, Armenia, Azerbaijan, Bulgaria, Georgia, Greece, Moldova, Romania, Russia, Turkey, and Ukraine. In the text, the parties state their intention to act to improve the environment and promote economic cooperation in the region.

Key words: Armenia, Azerbaijan, Bulgaria, Georgia, Romania, Russia, Turkey, Ukraine, Black Sea; economics, international agreements; Ministry of Foreign Affairs (Republic of Turkey)

\section{Oil Consortium Agreement with Azerbaijan}

http://www.american.edu/projects/mandala/TED/azeri.htm

1996. 7 pages. Narrative

On November 20,1994, a consortium of oil companies signed a contract with the nation of Azerbaijan. The consortium believes it can extract up to 4 billion barrels of oil from three wells in the Caspian Sea. The problem is the route to be used to take the oil to the world market. The consortium plans two pipelines: a Russian route and one through Georgia to the Black Sea. The potential remains for oil spill problems from pipeline breaks or shipping mishaps.

Key words: Azerbaijan, Russia; oil/natural gas; American University

\section{Black Sea Energy Review, Azerbaijan}

http://www.bsrec.bg/azerbaijan/azerbaijan.html

February 1997. 2 pages (table of contents). Links, map, interview

This energy review includes energy balance data, macroeconomic profile data, energy sector organization, energy pricing, energy legislation, economic legislation, financial sector, market reforms, investment opportunities, and an energy directory. Data are based on available technical and economic analysis and incorporate energy balance considerations due to the significance of energy to Azerbaijan economy. Special attention has been paid to the implementation of market reforms in the energy sector, promoting rehabilitation and development of the sector, supported by national legislation and foreign investment inflows.

Key words: Azerbaijan; energy, environment, natural gas/oil, GHG/GCC, economics; European Commission, Black Sea Regional Energy Centre.

\section{Azerbaijan}

http://www.caspianenvironment.org/azeinfo.htm

2000. 8 pages. Map, data 
This site provides background information on Azerbaijan. A number of unresolved conflicts with neighboring countries cloud Azerbaijan's oil rights in the Caspian Sea. The site contains data on geography, the environment, population, government, the economy (including electrical production), communications, transportation, the military, and transnational issues.

Key words: Azerbaijan; economics, environment, energy, international agreements; Caspian Environment Programme

\section{Caspian Environment Programme}

http://www.caspianenvironment.org/second.htm

2000. 1 page (home page). Links

The Caspian Environment Programme is a regional umbrella program established by the states bordering the Caspian Sea and aided by the international agencies. A 1998 concept paper (http://www.caspianenvironment.org/concept.htm) provides the basis for the program. Links are provided to current projects, technical publications, and other sites with data, projects, and supporting organizations.

Key words: Azerbaijan, Kazakhstan, Caspian Sea; environment, international agreements; Caspian Environmental Programme

\section{The World Factbook-Azerbaijan}

http://www.cia.gov/cia/publications/factbook/geos/aj.html

January 2000. 9 pages. Map, data

The site contains an assortment of data about Azerbaijan under the general topics of geography, people, government, economy, communications, transportation, military, and transnational issues. Site includes some information on the economy and electricity production and use, environment, and environmental agreements.

Key words: Azerbaijan; economics, environment, energy, international agreements; Central Intelligence Agency, U.S. government

\section{OPET (Organizations for the Promotion of Energy Technologies) Home Page} http://www.cordis.lu/opet/home.html

December 1999. 2 pages. Links to over 80 energy-related web sites worldwide

The OPET Network "aims to promote the results of new energy technologies and their introduction in society in order to improve energy efficiency and broaden the use of renewable 
energy sources." Links to related sites include European Commission projects, Energy/Environment Research Centers, Energy Trade Associations, publications, events, success stories, and directories. One FEMOPET project focused on the Black Sea Region from 1998 to 2000 (Bulgaria/Romania). This was followed by the Black Sea Region OPET Associate Project (2000-2002, Russia, Turkey, Ukraine). Both projects, in conjunction with the Black Sea Regional Energy Centre, aimed to promote innovative renewable and conservation energy technologies.

Key words: Armenia, Azerbaijan, Black Sea, Bulgaria, Caspian Sea, Romania, Russia, Turkey, Ukraine; energy, environment, oil/natural gas, GHG/GCC, economics, international agreements, institutional development; European Commission Thermie Program

\section{Country Brief: Caspian Sea Region}

http://www.eia.doe.gov/emeu/cabs/caspian.html

June 2000. 5 pages. Narrative, map, links to related sites

http://www.eia.doe.gov/emeu/cabs/caspfull.html approx 30-page, more detailed report, with tables

The site discusses the oil and gas reserves in the Caspian Sea regions, and issues and options for export routes, including those that impact Bulgaria, Georgia, Romania, Russia, Turkey, Ukraine, and the Black Sea. There is also a discussion of environmental issues affecting the Caspian Sea: oil pollution, waste discharges, sea rise, environmental legislation, and outlook for 21st century.

Key words: Azerbaijan, Bulgaria, Kazakhstan, Romania, Russia, Turkey, Ukraine, Black Sea, Caspian Sea; oil/natural gas, energy, environment, institutional development, international agreements; Energy Information Administration, U.S. government

\section{International Data: Azerbaijian}

http://www.eia.doe.gov/emeu/international/azerbjan.html

January 2000. 1 page. Links

Site contains links to spreadsheet energy and energy-related data for 1992-98, reported by fuel category, and a country energy balance. Links are provided to other reports.

Key words: Azerbaijan; energy, oil/natural gas, GHG/GCC; Energy Information Administration, U.S. government

\section{Azerbaijan}


http://www-esd.worldbank.org/ecssd/envcopg/esazer.html

August 1998. 4 pages. Map, narrative, data

The site contains a country map and data on land and water use, natural resources, biodiversity, energy efficiency, $\mathrm{CO}_{2}$ emissions, and treaty participation. The key environmental problems are briefly described. Current World Bank environment and rural development projects are listed, along with country and World Bank contacts.

Key words: Azerbaijan; environment, GHG/GCC; World Bank

\section{Azerbaijan ENRIN Home}

http://www.grida.no/enrin/htmls/azer/index.htm

May 1999. Home page, map, links.

Reports on the State of Environment (http://www.grida.no/enrin/htmls/azer/soe/ecology/ index.html) and Environmental Information Systems (http://www.grida.no/enrin/htmls/ azer/azerb.htm) are available for Azerbaijan. The Environment and Natural Resource Information Network (ENRIN) in Central and Eastern Europe and Newly Independent States (CEE/NIS) home page provides direct links to reports on 27 countries in the region, including 25 national State of Environment Reports, national contacts, regional activities, publications and other links.

Key words: Azerbaijan; environment, energy, institutional development; United Nations Environment Programme

\section{Key Energy Indicators for Azerbaijan}

http://www.iea.org/stats/files/selstats/keyindic/nmc/azerb.htm

1997. 2 pages. Data, chart, map, links

Key energy indicators are presented in a table. Data include population, GDP, energy supply, and electricity consumption. Energy supply and electricity consumption are also shown per capita and per GDP. The chart shows the portion of total energy production by fuel. Links to more detailed information are provided.

Key words: Azerbaijan; energy, economics; International Energy Agency, U.S. government

\section{Caspian Sea: Four Nations Pledge Cooperation on Energy} http://www.rferl.org/nca/features/2000/05/F.RU.000522131539.html

May 2000. 2 pages. Narrative 
This is a Radio Free Europe/Radio Liberty report on a May 19, 2000, seminar on energy, transportation, and security, held in Washington. There was a panel discussion that included representatives of Azerbaijan, Georgia, Kazakhstan, and Russia on the problems of getting oil and gas from the Caspian Sea-primarily the high cost of building pipelines and keeping them safe. Resolution of the conflict between Armenia and Azerbaijan would remove a major impediment development of the Caspian Sea's energy resources.

Key words: Azerbaijan, Georgia, Kazakhstan, Russia, Caspian Sea; oil/natural gas; Radio Free Europe/Radio Liberty

\section{United Nations Development Programme (UNDP) Global Environment Facility (GEF)}

http://www.undp.org/gef/portf/climeur.htm

September 2000, updated regularly. 7 pages. Table

UNDP-GEF maintains a current online portfolio of projects by country. Separate tables exist for different GEF focal areas: climate, biodiversity, international waters, and ozone depletion. Included in the portfolio tables are the country name, region, project name, project description, GEF allocation (in millions), and project type (the types are labeled as PDF- Project Development Facility; EA_-Enabling Activities; PRIF_-Pre-Investment Feasibility Study; FP-Full Project; MSP-Medium-size projects). The portfolio includes regional projects for both Black and Caspian Sea, as well as national projects in nearly every country of the region.

Key words: Armenia, Azerbaijan, Bulgaria, Georgia, Kazakhstan, Romania, Russia, Turkey, Ukraine, Black Sea, Caspian Sea; environment, GHG/GCC, institutional development; United Nations Development Programme

\section{United Nations Development Programme (UNDP) National Human Development Reports}

http://www.undp.org/hdro/table.htm

August 2000, updated frequently. 5 pages. Table of available reports, links

More than 100 countries have published National Human Development Reports with UNDP support. By providing comprehensive indicators, the reports help to monitor progress and setbacks in human development and poverty at the national-level. The annual summary report for 2000 is also available online at http://www.undp.org/hdr2000/english/HDR2000.html. The 2000 Human Development Report includes a summary of national indicators such as energy use, growing urbanization, profile of environmental degradation, and access to information and communications. Each report also focuses on a highly topical theme in the current development 
debate, providing path-breaking analysis and policy recommendations. Individual country reports for some years are available online.

Key words: Armenia, Azerbaijan, Bulgaria, Georgia, Kazakhstan, Romania, Russia, Turkey, Ukraine; energy, environment, GHG/GCC, economics; United Nations Development

Programme

\section{The Ozone Secretariat, UNEP-Nairobi, Kenya}

http://www.unep.ch/ozone/

August 2000. 1 page (home page). Links

Site contains a description of the activities of the Ozone Secretariat, with links to treaties, reports, addresses, and other sites. One of the linked sites (http://www.unep.ch/ozone/ratif.htm) shows each country's signature and ratification status on agreements on the protection of the stratospheric ozone layer.

Key words: Armenia, Azerbaijan, Bulgaria, Georgia, Kazakhstan, Romania, Russia, Turkey, Ukraine; environment, GHG/GCC, international agreements; United Nations Environment Programme

\section{Azerbaijan}

http://www.unfccc.de/resource/country/azer.html

September 2000. 1 page. Data, link

This United Nations web page shows Azerbaijan's status on signature and ratification of the United Nations Framework Convention and the Kyoto Protocol. Azerbaijan has ratified the Framework Convention. A link is provided to a contact point.

Key words: Azerbaijan; environment, GHG/GCC; United Nations Framework Convention on Climate Change

\section{USAID Country Profile: Azerbaijan}

http://www.usaid.gov/countries/az/aze.htm

January 1997. 2 pages. Narrative, data

Statistical summary on Azerbaijan and an overview of the U.S. Agency for International Development's strategic objectives to assist the nation with its (a) democratic transition, (b) economic restructuring, and (c) social stabilization (emergency humanitarian aid, primarily food and fuel). 
Key words: Azerbaijan; U.S. Agency for International Development, U.S. government

\section{U.S. Agency for International Development, USAID Azerbaijan}

http://www.usaid.gov/country/ee/az/

August 2000, updated annually. 3 pages. Links.

An overview of U.S. assistance priorities in Azerbaijan, discussing the political setting, development challenges and other donor activities. U.S. priorities include assisting Azerbaijan with its transition to a democratic society and an open-market economy. Details by sector (democracy, private enterprise, social assistance) can be accessed through the "2001 Program/Activities" link.

Key words: Azerbaijan; economics; U.S. Agency for International Development, U.S. government

\section{USAID, FY2000 Congressional Presentation, Azerbaijan}

http://www.usaid.gov/pubs/cp2000/eni/azerbaij.html

July 2000, updated annually. 20 pages. Narrative, data

Summary of development challenges facing Azerbaijan and U.S. Agency for International Development's program to address them. Includes FY2000 budget tables and descriptions for democracy, private enterprise, and social assistance programs.

Key words: Azerbaijan; economics; U.S. Agency for International Development, U.S. government

\section{Azerbaijan-Energy Information}

http://www.worldenergy.org/wec-geis/members only/registered/open.plx?file=edc/default/ country/AZE.stm

1998. 4 pages. Narrative, data

This brief description includes short discussions of crude oil and liquid natural gas, natural gas, downstream gas, upstream oil and gas, and electricity. Azerbaijan is among the world's oldest producers of oil and natural gas. New oil resources are offshore in the Caspian Sea. Lack of transmission and processing facilities has limited the use of its natural gas resource. Most of the energy industry is still state-owned.

Key words: Azerbaijan; energy, oil/natural gas; World Energy Council 


\section{Azerbaijan at a Glance: Agriculture, Natural Resources, and Environment http://www.wri.org/facts/cs-pdf/azerbi.pdf}

1997. 4 pages. Data, charts (PDF format)

This World Resources Institute fact sheet highlights data on Azerbaijan's economic and social context, agricultural resources, forests, freshwater, marine and coastal resources, biodiversity resources, energy and mineral resources, and involvement in international agreements. The data for these fact sheets came from the World Resources 1996-97 database; the project was funded by the Agriculture and Natural Resource Department of the World Bank.

Key words: Azerbaijan; economics, environment, energy, international agreements; World Resources Institute

\section{R. Cullen, "The Caspian Sea" \\ National Geographic}

May 1999. Pages 2-35. Maps, photos, narrative.

"The Soviet Union's breakup left regional economies in tatters; it also spurred the biggest oil rush of the past quarter century." This article documents the social, economic, cultural and environmental issues affecting the countries surrounding the Caspian, and its natural resources. Regional maps and keys depict such factors as income level, gas and oil reserves, landscapes, ethnolinguistic groups, oil/gas pipelines, sturgeon catch, etc.

Key words: Azerbaijan, Kazakhstan, Russia, Caspian Sea; energy, environment, economics, oil/natural gas; National Geographic Society.

\section{Black Sea Energy Survey}

International Energy Agency

June 2000. 256 pages

This study of the Black Sea region as a whole looks at its energy needs and how future oil and gas transport in the region could develop. It reviews the energy policies and sectors of seven countries with diverse energy situations. Azerbaijan is a major oil producer and exporter; Armenia and Georgia are energy-poor; Bulgaria and Romania are EU accession candidates which must restructure their domestic oil and coal industries; Greece and Turkey are IEA member states. This study covers energy strategies, institutions, and restructuring, as well as recent and projected energy trends in these countries. The book analyzes the reforms that are still needed to attract significant investment, both in domestic energy projects and in regional energy trade. A table of contents, sample material, and ordering information are found at http://www.iea.org/pubs/studies/files/blacksea/index.htm . 
Key words: Black Sea, Armenia, Azerbaijan, Bulgaria, Georgia, Romania, Turkey; energy, oil/natural gas, economics; International Energy Agency

\section{Caspian Oil and Gas: The Supply Potential of Central Asia and Transcaucasia} International Energy Agency

May 1998. 297 pages

The Caspian region has the potential to become a significant producer and exporter of oil and gas. This comprehensive study provides data on, detailed descriptions of, and analysis of the oil and gas sectors of Azerbaijan, Kazakstan, Turkmenistan and Uzbekistan. It looks at the potential for oil and gas production and exports and points out technical, legal, financial, and other barriers to fulfilling this potential. The report also examines oil and gas pipeline routes, export markets, investment frameworks and major investment projects under way and planned. A table of contents, sample content, and ordering information can be found at http://www.iea.org/pubs/studies/files/caspian/index.htm .

Key words: Caspian Sea, Azerbaijan, Kazakhstan; energy, oil/natural gas, economics; International Energy Agency

\section{World Resources, 1998-1999}

World Resources Institute, United Nations Environment Programme, United Nations Development Programme, World Bank, Oxford University Press (USA) 1998. 384 pages. Database is also available on CD-ROM and diskette

This biennial report looks at the current state of the environment as it relates to population and human well-being, consumption and waste, and resources at risk. The book also contains country data from 157 countries and new information on poverty, inequality, and food security.

Key words: Armenia, Azerbaijan, Bulgaria, Georgia, Kazakhstan, Romania, Russia, Turkey, Ukraine; economics, environment, energy, GHG/GCC, gas/oil, international agreements; World Resources Institute

\section{BULGARIA}

Event: Bright Role for Innovation in the Black Sea, June 5-7, 2001 http://dbs.cordis.lu/cordis-cgi/srchidadb?ACTION=D\&SESSION=199642000-9$18 \& D O C=29 \&$ TBL $=$ EN NEWS \&RCN=EN RCN ID:15339\&CALLER=EN UNIFIEDS $\underline{\mathrm{RCH}}$ (or search from CORDIS home page for Black Sea events) August 2000. 1 page 
The role of research and innovation in the reconstruction and development of the Black Sea Economic Community (BSEC) countries will be discussed at a forthcoming conference in Kharkov, the Ukraine, on June 5-7, 2001. Contact: email: ump@ vlink.kharkov.ua . This is an example of information available from the http://www.cordis.lu/en/home.html search system.

Key words: Black Sea, Bulgaria, Georgia, Romania, Russia, Turkey, Ukraine; economics; European Union International Scientific Cooperation

\section{Summit Declaration on Black Sea Economic Cooperation http://inter.mfa.gov.tr/grupa/af/Bsec7.HTM \\ June 1992. 2 pages. Narrative}

This site contains the text of the summit declaration at Istanbul, June 25, 1992, agreed to by the heads of state or governments of Albania, Armenia, Azerbaijan, Bulgaria, Georgia, Greece, Moldova, Romania, Russia, Turkey, and Ukraine. In the text, the parties state their intention to act to improve the environment and promote economic cooperation in the region.

Key words: Armenia, Azerbaijan, Bulgaria, Georgia, Romania, Russia, Turkey, Ukraine, Black Sea; economics, international agreements; Ministry of Foreign Affairs (Republic of Turkey)

\section{Black Sea Environmental Information Center}

http://pims.ed.ornl.gov/blacksea/

2000. 1 page (home page). Links

This site provides information and training on environmental issues and problems related to the Black Sea. The web site provides information on oil spill clean-up and related commercial technologies; various countries' laws, regulations, and standards relating to the environmental condition of the Black Sea; and individuals and companies working on Black Sea environmental issues. The web site provides a real-time chat capability which enables meetings to be conducted online. There is also is an area for scientists to post scientific papers and requests for research partners. The web site is also host to a growing database of historical pollution testing data from research institutes around the Black Sea.

Key words: Bulgaria, Georgia, Romania, Russia, Turkey, Ukraine, Black Sea; environment, international agreements; U.S. Department of Energy

\section{Protocol on Protection of the Black Sea Marine Environment Against Pollution from Land Based Sources \\ http://sedac.ciesin.org/pidb/texts/acrc/BlackSeaLBP.txt.html}


1998 (web site). April 1992 (Convention and protocol). 7 pages. Narrative.

This protocol to the Convention on the Protection of the Black Sea against Pollution describes procedures and definitions for preventing, reducing and controlling pollution from land based sources that impact on the Black Sea. The Socioeconomic Data Applications Center (SEDAC) maintains the Center for International Earth Science Information Network (CIESIN) Environmental Treaties and Resource Indicators (ENTRI) online at http://sedac.ciesin.org/entri/. Summaries, information on status, and full text for many international treaties and conventions are available.

Key words: Bulgaria, Georgia, Romania, Russia, Black Sea; environment, international agreements; Center for International Earth Science Information Network

\section{Bulgaria Nuclear Power Plant-Kozloduy}

http://www.american.edu/projects/mandala/TED/bulgarnk.htm

1998. 15 pages. Narrative

In 1993, Bulgaria agreed to close the old Units 1-4 of the Kozloduy Nuclear Plant by the end of 1998, in return for installation of new power-generating facilities and modernization of Units 5 and 6. This site describes the reactor units in question. Bulgaria has made improvements to the reactors; it is reluctant to close the older units because it is more that $70 \%$ dependent on external energy sources.

Key words: Bulgaria; energy, environment; American University

\section{Danube Pollution}

http://www.american.edu/projects/mandala/TED/danube.htm

1994. 7 pages. Narrative

Five major rivers and 165 million people in 17 countries contribute to the pollution of the Danube River. The river absorbs raw sewage from cities, pesticides and chemicals from farmers' fields, waste from factories, and bilge oil from ships. In a period of economic recession, most countries have not chosen to close plants to preserve the river.

Key words: Bulgaria, Romania; environment; American University

\section{Black Sea Web Homepage}

http://www.blackseaweb.net/welcome.html

1999. 1 page (home page). Links 
The Black Sea Web is an attempt to provide a management tool and information to assist in integrated marine environmental management of the Black Sea area. The site provides links to map sets (digital atlas, satellite images, thematic maps), data on each of the countries bordering the Black Sea (http://www.blackseaweb.net/general/country.htm), lists of existing environmental programs (http://www.blackseaweb.net/general/epp.htm), list of publications from the Black Sea Environmental Programme (http://www.blackseaweb.net/publications/welcome.html), and a set of environmental links for Bulgaria, Georgia, Romania, Russia, and Ukraine (http://www.blackseaweb.net/general/links.htm). The site also contains a Demonstrator (http://www.blackseaweb.net/demonstrator/welcome.html), which allows a number of physically and geographically separate databases to be accessed remotely through a "Black Sea Web Interface."

Key words: Bulgaria, Georgia, Romania, Russia, Turkey, Ukraine, Black Sea; environment; Black Sea Web Project

\section{Black Sea Energy Review, Bulgaria}

http://www.bsrec.bg/bulgaria/bulgaria.html

September 1996. 1 page (table of contents). Links

Bulgaria's main energy policy objective is a secure supply of fuels and energy to meet demand at minimized costs, while at the same time observing the requirements for environmental protection and addressing the social and regional problems of the country. This energy review includes a map and interview. The report includes energy balance and macroeconomic profile data; information on energy sector organization, energy pricing, energy legislation, economic legislation, the financial sector, market reforms, and investment opportunities; and an energy directory.

Key words: Bulgaria; energy, environment, oil/natural gas, GHG/GCC, economics; European Commission, Black Sea Regional Energy Centre. 


\section{Black Sea Oil, Gas, Coal Exploration and Production}

http://www.bsrec.bg/PHARE/prog95/project1/index.html

November 1998. 1 page (title page). Links to document

Although local production of oil and gas contributes only partly to the energy demand of the western Black Sea Region, the potential to develop additional production exists (to a variable degree) in each of the countries of the region. A country analysis is provided for Bulgaria and Romania. Governments are urged to modernize commercial laws, but structural changes in the government oil and gas industries and agencies, foreign investment and technology transfer are necessary for exploration and production development. Modernization and major investments are required to maintain or increase coal production and reduce the environmental problems created by coal mining practices in the region.

Key words: Bulgaria, Romania; energy, oil/gas; Black Sea Regional Energy Centre

\section{The World Factbook—Bulgaria}

http://www.cia.gov/cia/publications/factbook/geos/bu.html

January 2000. 8 pages. Map, data

An assortment of data about Bulgaria under the general topics of geography, people, government, economy, communications, transportation, military, and transnational issues. Site includes some information on the economy and electricity production and use, environment, and environmental agreements.

Key words: Bulgaria; economics, environment, energy, international agreements; Central Intelligence Agency, U.S. government

\section{OPET (Organizations for the Promotion of Energy Technologies) Home Page} http://www.cordis.lu/opet/home.html

December 1999. 2 pages. Links to over 80 energy-related web sites worldwide

The OPET Network "aims to promote the results of new energy technologies and their introduction in society in order to improve energy efficiency and broaden the use of renewable energy sources." Links to related sites include European Commission projects, Energy/Environment Research Centers, Energy Trade Associations, publications, events, success stories, and directories. One FEMOPET project focused on the Black Sea Region from 1998 to 2000 (Bulgaria/Romania). This was followed by the Black Sea Region OPET Associate Project (2000-2002, Russia, Turkey, Ukraine). Both projects, in conjunction with the Black Sea Regional Energy Centre, aimed to promote innovative renewable and conservation energy technologies. 
Key words: Armenia, Azerbaijan, Black Sea, Bulgaria, Caspian Sea, Romania, Russia, Turkey, Ukraine; energy, environment, oil/natural gas, GHG/GCC, economics, international agreements, institutional development; European Commission Thermie Program

\section{Black Sea Environmental Programme \\ http://www.dominet.com.tr/blacksea/ \\ 1996. 3 pages (home page). Links}

This home page contains a series of links grouped under general topics. Some of the linked material describes the background and structure of the Black Sea Environmental Programme and the Black Sea Environmental Programme Institutional Network. Other links describe the program in 1996 and its activities that year in emergency response, pollution monitoring, biodiversity, integrated coastal zone management, fisheries, database management and geographic information system, environmental economics and investments, nongovernmental organizations, information and communication, and policy and legislation.

Key words: Black Sea, Bulgaria, Georgia, Romania, Russia, Turkey, Ukraine; environment, institutional development, international agreements; Black Sea Environmental Programme, United Nations

\section{Strategic Action Plan for the Rehabilitation and Protection of the Black Sea http://www.eelink.net/ asilwildlife/blacksea.html}

October 1996. 23 pages. Narrative

Site contains text of an agreement among Bulgaria, Georgia, Romania, the Russian Federation, Turkey, and Ukraine, October 30-31, 1996. EE-Link (http://www.eelink.net/) also provides access to other international agreements relating to this region.

Key words: Bulgaria, Georgia, Romania, Russia, Turkey, Ukraine, Black Sea; environment, institutional development, international agreements; EE (Environmental Education) Link

\section{Country Brief: Caspian-Bosporus/Black Sea Issues}

http://www.eia.doe.gov/emeu/cabs/caspblk.html

June 2000. 3 pages. Narrative

Site summarizes issues and concerns about proposed increases in shipment of oil from the Caspian Sea area through the Black Sea and the Bosporus. Impacts on Turkey, Bulgaria, Croatia, Moldova, Romania, and Ukraine are identified. 
Key words: Bulgaria, Romania, Turkey, Ukraine, Black Sea, Caspian Sea; environment, oil/natural gas; Energy Information Administration, U.S. government

\section{Country Brief: Caspian Sea Region}

http://www.eia.doe.gov/emeu/cabs/caspian.html

June 2000. 5 pages. Narrative, map, links to related sites

http://www.eia.doe.gov/emeu/cabs/caspfull.html approx 30-page, more detailed report, with tables

The site discusses the oil and gas reserves in the Caspian Sea regions, and issues and options for export routes, including those that impact Bulgaria, Georgia, Romania, Russia, Turkey, Ukraine, and the Black Sea. There is also a discussion of environmental issues affecting the Caspian Sea: oil pollution, waste discharges, sea rise, environmental legislation, and outlook for 21 st century.

\section{International Data: Bulgaria}

http://www.eia.doe.gov/emeu/international/bulgaria.html

January 2000. 1 page. Links

Site contains links to spreadsheet energy and energy-related data for 1980-98, reported by fuel category, and a country energy balance. Links are provided to other reports.

Key words: Bulgaria; energy, oil/gas, GHG/GCC; Energy Information Administration, U.S. government

\section{Bulgaria}

http://www-esd.worldbank.org/ecssd/envcopg/esbulg.html

August 1998. 4 pages. Map, narrative, data

The site contains a country map and data on land and water use, natural resources, biodiversity, energy efficiency, $\mathrm{CO}_{2}$ emissions, and treaty participation. The key environmental problems are briefly described. Current World Bank environment and rural development projects are listed, along with country and World Bank contacts.

Key words: Bulgaria; environment, GHG/GCC; World Bank

\section{An Energy Overview of the Republic of Bulgaria}

http://www.fe.doe.gov/international/bulgover.html 
September 2000. 13 pages. Narrative, data

This site summarizes the Republic of Bulgaria's energy situation. Energy use in Bulgaria is significantly higher than in a comparable market economy. The overview considers production and consumption of oil, natural gas, and coal. It considers hydroelectric resources and energy infrastructure. Current electricity generation and planned generation capacity are summarized. The site briefly discusses environmental concerns, $\mathrm{CO}_{2}$ emissions, and economic conditions.

Key words: Bulgaria; energy, oil/natural gas, economic, environment, GHG/GCC; U.S. Department of Energy, U.S. government

\section{Black Sea Internet Node}

http://www.grid.unep.ch/bsein/

June 1999. 1 page (home page). Links

This site contains links to information on organizations and scientists studying the Black Sea; (inter)national research projects/programs (since 1990); cruise summary reports (since 1979); Black Sea bibliography (since 1974); acronyms and abbreviations; meta level information on environmental data for the Black Sea region; selected satellite images; and Black Sea Red Data Book (flora and fauna of region). It also contains recent data sets obtained in frameworks of different international programs and copies of some historical data sets opened for public use.

Key words: Bulgaria, Georgia, Romania, Russia, Turkey, Ukraine, Black Sea; environment, international agreements; Black Sea Environment Programme

\section{Black Sea Transboundary Diagnostic Analysis}

http://www.grid.unep.ch/bsein/tda/index.htm

June 1996. 1 page (entry page). Narrative, tables, charts

The web version of the lengthy document is broken into sections accessed from the "Content" page. (Choose "Continue" on entry page.) This report represents the results of a systematic scientific analysis of the root causes of environmental degradation in the Black Sea. The document was prepared by an international team of specialists, most from institutions in the six coastal countries. The report contains information on the environmental problems and causes, major sources and reduction of pollution, fisheries, protection of endangered species and habitats, conservation area management, and sustainable development.

Key words: Bulgaria, Georgia, Romania, Russia, Turkey, Ukraine, Black Sea; environment, international agreements; Global Environmental, Facility Black Sea Environment Programme 


\section{Biodiversity in Bulgaria}

http://www.grida.no/enrin/biodiv/biodiv/national/bulgaria/intro.htm

2000. 1 page. Narrative, link

This page is the introduction to the biodiversity report. From this page, one can link to the table of contents or the next page of the report. The report covers the existing biological species and the threats to the environment (including human activities), as well as the actions being taken to preserve biodiversity.

Key words: Bulgaria; environment, institutional development, international agreements; Ministry of Environment and Water (Bulgaria)

\section{Key Energy Indicators for Bulgaria}

http://www.iea.org/stats/files/selstats/keyindic/nmc/bulgaria.htm

1997. 2 pages. Data, chart, map, links

Key energy indicators are presented in a table. Data include population, GDP, energy supply, and electricity consumption. Energy supply and electricity consumption are also shown per capita and per GDP. The chart shows the portion of total energy production by fuel. Links to more detailed information are provided.

Key words: Bulgaria; energy, economics; International Energy Agency

\section{Facts and Figures: Environmental Data Tables}

http://www.igc.org/wri/facts/data-tables.html

March 2000. 1 page. Links

This page presents links to data tables taken from World Resources 1998-1999. These tables (in PDF format) contain information on atmosphere and climate, biodiversity, economic indicators, energy and materials, food and agriculture, forests and land cover, freshwater, health, oceans and fisheries, population and human development, and urban data.

Key words: Armenia, Azerbaijan, Bulgaria, Georgia, Kazakhstan, Romania, Russia, Turkey, Ukraine; economics, environment, energy, GHG/GCC, gas/oil, international agreements; World Resources Institute 


\section{The Black Sea Economic Co-Operation and the EU}

http://www.mfa.gov.tr/grupa/percept/i3/I3-6.htm

September-November 1996. 7 pages. Narrative

Article by Ercan Özer in Perceptions: Journal of International Affairs 1(3), Center for Strategic Research, Ankara, Turkey, September-November 1997. The article argues that the European Union and the Black Sea Economic Cooperation can be mutually beneficial organizations and that there are many perspective avenues for cooperation, including the energy resources of the Black Sea area, economic reform, and ending the pollution of the Black Sea.

Key words: Bulgaria, Georgia, Romania, Russia, Turkey, Ukraine, Black Sea; economics, environment, international agreements; Center for Strategic Research

\section{Welcome to the Ministry of Environment and Water, Bulgaria}

http://www.moew.government.bg/indexengl.htm (English)

April 2000. 1 page (index). Links

Site provides information on the mission and priorities, European Integration, legislation, sixyear national development program plan, biodiversity, projects and partners, search engines, and feedback page for comments.

Key words: Bulgaria; environment; Ministry of Environment and Water (Bulgaria)

\section{Fluxes of Greenhouse Gases in the Northwestern Region of the Black Sea Coastal Zone-Influence of the Danube River System}

http://www.nitg.tno.nl/eng/projects/3 danube/index.shtml

No date given. 1 page (first of 3 linked pages)

The site describes an ongoing project (in the second of three years) to measure greenhouse gases in natural sediments within the Danube Delta. The project aims to evaluate the contribution of gas expulsions from different parts of the delta; evaluate and model the effects of river channels and arms on gas production in shallow lakes; calculate total annual fluxes of $\mathrm{CO}_{2}, \mathrm{~N}_{2} \mathrm{O}$, and $\mathrm{CH}_{4}$ from the entire delta region; and to provide model input for predicting the changes in gas emissions due to changes in the delta morphology and ecology.

Key words: Bulgaria, Romania, Ukraine, Black Sea; GHG/GCC; Netherlands Institute of Applied Geoscience TNO-National Geological Survey

\section{Sustainable Development: Information on Bulgaria}


http://www.un.org/esa/agenda21/natlinfo/countr/bulgaria/index.htm

2000. 1 page. Links

This page provides links to information on four aspects of sustainable development in Bulgaria: social, natural resource, economic, and institutional. A series of indicators (statistical data) are provided for each aspect. More detail is provided for identified subtopics under each indicator.

Key words: Bulgaria; energy, environment, GHG/GCC, institutional development, international agreements; United Nations

\section{United Nations Development Programme (UNDP) Global Environment Facility (GEF)}

http://www.undp.org/gef/portf/climeur.htm

September 2000, updated regularly. 7 pages. Table

UNDP-GEF maintains a current online portfolio of projects by country. Separate tables exist for different GEF focal areas: climate, biodiversity, international waters, and ozone depletion. Included in the portfolio tables are the country name, region, project name, project description, GEF allocation (in millions), and project type (the types are labeled as PDF- Project Development Facility; EA_-Enabling Activities; PRIF_-Pre-Investment Feasibility Study; FP_Full Project; MSP_-Medium-size projects). The portfolio includes regional projects for both Black and Caspian Sea, as well as national projects in nearly every country of the region.

Key words: Armenia, Azerbaijan, Bulgaria, Georgia, Kazakhstan, Romania, Russia, Turkey, Ukraine, Black Sea, Caspian Sea; environment, GHG/GCC, institutional development; United Nations Development Programme

\section{United Nations Development Programme (UNDP) National Human Development Reports}

http://www.undp.org/hdro/table.htm

August 2000, updated frequently. 5 pages. Table of available reports, links

More than 100 countries have published National Human Development Reports with UNDP support. By providing comprehensive indicators, the reports help to monitor progress and setbacks in human development and poverty at the national-level. The annual summary report for 2000 is also available online at http://www.undp.org/hdr2000/english/HDR2000.html. The 2000 Human Development Report includes a summary of national indicators such as energy use, growing urbanization, profile of environmental degradation, and access to information and communications. Each report also focuses on a highly topical theme in the current development 
debate, providing path-breaking analysis and policy recommendations. Individual country reports for some years are available online.

Key words: Armenia, Azerbaijan, Bulgaria, Georgia, Kazakhstan, Romania, Russia, Turkey, Ukraine; energy, environment, GHG/GCC, economics; United Nations Development

Programme

\section{The Ozone Secretariat, UNEP-Nairobi, Kenya}

http://www.unep.ch/ozone/

August 2000. 1 page (home page). Links

Site contains a description of the activities of the Ozone Secretariat, with links to treaties, reports, addresses, and other sites. One of the linked sites (http://www.unep.ch/ozone/ratif.htm) shows each country's signature and ratification status on agreements on the protection of the stratospheric ozone layer.

Key words: Armenia, Azerbaijan, Bulgaria, Georgia, Kazakhstan, Romania, Russia, Turkey, Ukraine; environment, GHG/GCC, international agreements; United Nations Environment Programme

\section{Bulgaria}

http://www.unfccc.de/resource/country/bulgaria.html

September 2000.1 page. Data, links

This United Nations web page shows Bulgaria's status on signature and ratification of the United Nations Framework Convention and the Kyoto Protocol. Bulgaria has ratified the Framework Convention and signed the Kyoto Protocol. Links are provided to the first and second national communication (status reports), an in-depth review of the first communication, and contact points.

Key words: Bulgaria; environment, GHG/GCC; United Nations Framework Convention on Climate Change

\section{U.S. Agency for International Development, Program Overview, Bulgaria} http://www.usaid.gov/country/ee/bg/

August 2000, updated annually. 3 pages. Narrative, links

Based on annual U.S. Agency for International Development (USAID) Congressional presentations, the overview provides a frank assessment of development challenges (political 
and economic issues); an overview of U.S. assistance priorities, programs, progress, and funding; and a summary of other donor activities. U.S. priorities include assisting Bulgaria with democratic transition, economic growth and reforms, and preparations for eventual European Union (EU) accession. Programs are in place to restructure and modernize financial and legal/judicial sectors, private enterprise development, citizen participation, and local governance. Details by sector-including objectives, indicators, budgets, other donors and progress to date — can be accessed through the "2001 Program/Activities" link. Links are provided to additional USAID program reports, budget tables, a search engine, and State Department information

Key words: Bulgaria, economics, U.S. Agency for International Development, U.S. government

\section{GEF Bulgarian Biodiversity Project}

http://www.usaid.gov/regions/europe eurasia/enr/projects/BULGARIA.HTM

January 1998. 3 pages

The project, funded by U.S. Agency for International Development, the Global Environment Facility (GEF), the United Nations, the European Community, the United Kingdom, and Switzerland, was created to help implement Bulgaria's National Biological Diversity Conservation Strategy (NBDCS), including support for the newly created National Nature Protection Service (NNPS) and development of a comprehensive management plan.

Key words: Bulgaria; environment; U.S. Agency for International Development, Global Environment Facility

\section{Energy Trends in WEC Member Countries 1980-1996}

http://www.worldenergy.org/wec-geis/members only/registered/open.plx?file=edc/ default/country/ned/curr/summarydocs/NedSUMtrends.htm

1999. 3 pages. Narrative, charts, links to tabular data

This report provides a summary of energy trends between 1980 and 1986 in selected countries. Primary energy supply in the World Energy Council (WEC) member countries increased by 1.7 $\%$ on average between 1980 and 1996, but this average hides large differences among countries. Links are provided to 12 tables containing energy trend data by country. Data are included on indigenous energy production, energy supply and demand, and electricity supply.

Key words: Bulgaria, Romania, Russia, Turkey, Ukraine; energy; World Energy Council 


\section{Bulgaria-Energy Information}

http://www.worldenergy.org/wec-geis/members only/registered/open.plx?file=edc/ default/country/BGR.stm

1998. 3 pages. Narrative, data, links

This brief description includes short discussions on coal, crude oil and liquid natural gas, nuclear power, and electricity. Bulgaria is dependent on coal imports for electricity generation; $42 \%$ of electricity in 1996 was generated by nuclear power. Electrical capacity is state-owned, but it is in the process of liberalization. Links are provided to statistical tables containing energy data, energy supply and demand, electricity supply, and $\mathrm{CO}_{2}$ emissions.

Key words: Bulgaria; energy, oil/gas, GHG/GCC; World Energy Council

\section{Bulgaria at a Glance: Agriculture, Natural Resources, and Environment http://www.wri.org/facts/cs-pdf/bulgaria.pdf}

1997. 4 pages. Data, charts (PDF format)

This World Resources Institute fact sheet highlights data on Bulgaria's economic and social context; agricultural, forest, freshwater, marine, coastal, and biodiversity resources; energy and mineral resources; and involvement in international agreements. The data for these fact sheets came from the World Resources 1996-97 database, and the project was funded by the Agriculture and Natural Resource Department of the World Bank.

Key words: Bulgaria; economics, environment, energy, international agreements; World Resources Institute

\section{World Energy Council-Survey of Energy Resources, 1998}

http://www.worldenergy.org/wec-geis/publications/open.plx?file=default/current ser.htm 1998. 1 page. Table of contents, with links to each section

The 1998 survey provides an updated review of world energy resources. It reports the adequacy of the world's total energy resource base and highlights, to an increasing degree, the environmental advantages and disadvantages of each fuel, with a particular and growing emphasis on $\mathrm{CO}_{2}$ and other greenhouse gas emissions. The dominance of the main commercial fossil fuels — oil, gas, and coal—is expected to continue for the foreseeable future, with the share of natural gas increasing. Several renewable energies (e.g., solar, wind) seem to be set on the path of rapid growth and declining cost. This should see them securing competitive advantage, initially in key niche areas, before broadening in role and importance. Site includes data tables with country information. 
Key words: Armenia, Azerbaijan, Bulgaria, Georgia, Kazakhstan, Romania, Russia, Turkey, Ukraine; energy, environment, oil/natural gas, GHG/GCC; World Energy Council

\section{Black Sea: Voyage of Healing}

Bullfrog Films, Oley, Penn.

1998. 54-min. color video

This video chronicles a symposium on the Black Sea in Crisis, held aboard a cruise ship as it visits the countries of Georgia, Russia, Ukraine, Romania, Bulgaria, and Turkey, in a circumnavigation of the sea. The symposium was convened by the ecumenical patriarch, Bartholomew of Constantinople, of the Eastern Orthodox Church, in hopes of finding solutions to the problems of the Black Sea region. The participants included environmentalists, scientists, writers, and religious thinkers.

Key words: Black Sea, Bulgaria, Georgia, Romania, Russia, Turkey, Ukraine; environment; Bullfrog Films

\section{Black Sea Energy Survey}

International Energy Agency

June 2000. 256 pages

This study of the Black Sea region as a whole looks at its energy needs and how future oil and gas transport in the region could develop. It reviews the energy policies and sectors of seven countries with diverse energy situations. Azerbaijan is a major oil producer and exporter; Armenia and Georgia are energy-poor; Bulgaria and Romania are EU accession candidates which must restructure their domestic oil and coal industries; Greece and Turkey are IEA member states. This study covers energy strategies, institutions, and restructuring, as well as recent and projected energy trends in these countries. The book analyzes the reforms that are still needed to attract significant investment, both in domestic energy projects and in regional energy trade. A table of contents, sample material, and ordering information are found at http://www.iea.org/pubs/studies/files/blacksea/index.htm .

Key words: Black Sea, Armenia, Azerbaijan, Bulgaria, Georgia, Romania, Turkey; energy, oil/gas, economics; International Energy Agency

\section{World Resources, 1998-1999}

World Resources Institute, United Nations Environment Programme, United Nations Development Programme, World Bank, Oxford University Press (USA) 1998. 384 pages. Database is also available on CD-ROM and diskette 
This biennial report looks at the current state of the environment as it relates to population and human well-being, consumption and waste, and resources at risk. The book also contains country data from 157 countries and new information on poverty, inequality, and food security.

Key words: Armenia, Azerbaijan, Bulgaria, Georgia, Kazakhstan, Romania, Russia, Turkey, Ukraine; economics, environment, energy, GHG/GCC, oil/natural gas, international agreements; World Resources Institute

\section{GEORGIA}

\section{Summit Declaration on Black Sea Economic Cooperation}

http://inter.mfa.gov.tr/grupa/af/Bsec7.HTM

June 1992. 2 pages. Narrative

This site contains the text of the summit declaration at Istanbul, June 25, 1992, agreed to by the heads of state or governments of Albania, Armenia, Azerbaijan, Bulgaria, Georgia, Greece, Moldova, Romania, Russia, Turkey, and Ukraine. In the text, the parties state their intention to act to improve the environment and promote economic cooperation in the region.

Key words: Armenia, Azerbaijan, Bulgaria, Georgia, Romania, Russia, Turkey, Ukraine, Black Sea; economics, international agreements; Ministry of Foreign Affairs (Republic of Turkey)

\section{State of Environment in Tblisi 2000}

http://ceroi.net/reports/tbilisi/

August 2000. Contents page linked to full report, data, maps, photos, graphs

Clicking on icons allows the reader to go quickly to a desired chapter of the report. Physical and social environmental conditions are analyzed along with external impacts. Sources of the problems are assessed (energy, industry, recreation, transport) and efforts to improve conditions are reviewed, including exploration for geothermal resources. There are also sections on recent news, indictors, and other information resources and actions. See also Cities Environment Reports on Internet, CERIO (http://ceroi.net/) for other urban environmental analyses.

Key words: Georgia; environment, energy; United Nations Environment Programme

Event: Bright Role for Innovation in the Black Sea, June 5-7, 2001 
http://dbs.cordis.lu/cordis-cgi/srchidadb?ACTION=D\&SESSION=199642000-9$18 \& D O C=29 \&$ TBL $=E N$ NEWS $\&$ RCN=EN RCN ID:15339\&CALLER=EN UNIFIEDS

$\underline{\mathrm{RCH}}$ (or search from CORDIS home page for Black Sea events)

August 2000. 1 page

The role of research and innovation in the reconstruction and development of the Black Sea Economic Community (BSEC) countries will be discussed at a forthcoming conference in Kharkov, the Ukraine, on June 5-7, 2001. Contact: email: ump@vlink.kharkov.ua . This is an example of information available from the http://www.cordis.lu/en/home.html search system.

Key words: Black Sea, Bulgaria, Georgia, Romania, Russia, Turkey, Ukraine; economics; European Union International Scientific Cooperation

\section{Black Sea Environmental Information Center}

http://pims.ed.ornl.gov/blacksea/

2000. 1 page (home page). Links

This site provides information and training on environmental issues and problems related to the Black Sea. The web site provides information on oil spill clean-up and related commercial technologies; various countries' laws, regulations, and standards relating to the environmental condition of the Black Sea; and individuals and companies working on Black Sea environmental issues. The web site provides a real-time chat capability which enables meetings to be conducted online. There is also is an area for scientists to post scientific papers and requests for research partners. The web site is also host to a growing database of historical pollution testing data from research institutes around the Black Sea.

Key words: Bulgaria, Georgia, Romania, Russia, Turkey, Ukraine, Black Sea; environment, international agreements; U.S. Department of Energy

\section{Protocol on Protection of the Black Sea Marine Environment Against Pollution from Land Based Sources}

http://sedac.ciesin.org/pidb/texts/acrc/BlackSeaLBP.txt.html

1998 (web site). April 1992 (Convention and protocol). 7 pages. Narrative.

This protocol to the Convention on the Protection of the Black Sea against Pollution describes procedures and definitions for preventing, reducing and controlling pollution from land based sources that impact on the Black Sea. The Socioeconomic Data Applications Center (SEDAC) maintains the Center for International Earth Science Information Network (CIESIN) Environmental Treaties and Resource Indicators (ENTRI) online at http://sedac.ciesin.org/entri/. 
Summaries, information on status, and full text for many international treaties and conventions are available.

Key words: Bulgaria, Georgia, Romania, Russia, Black Sea; environment, international agreements; Center for International Earth Science Information Network

\section{Caspian Oil and Political Implications}

http://www.american.edu/projects/mandala/TED/caspoil.htm

1998. 9 pages. Narrative

Although once thought minimal, Caspian oil reserves are now considered more plentiful than Persian Gulf oil. This paper discusses the various claims on Caspian oil, and the political complications of various pipeline routes from the area. Tensions between Armenia and Azerbaijan threaten the shortest route between Baku and Turkey. Once the oil reaches the Black Sea, the most viable option is to ship it through the Bosporus. This route, however, has environmental implications because there are frequent oil leaks from tankers working their way through the narrow straits

Key words: Armenia, Azerbaijan, Russia, Georgia, Turkey, Black Sea, Caspian Sea; oil/natural gas, environment; American University

\section{Black Sea Web Homepage}

http://www.blackseaweb.net/welcome.html

1999. 1 page (home page). Links

The Black Sea Web is an attempt to provide a management tool and information to assist in integrated marine environmental management of the Black Sea area. The site provides links to map sets (digital atlas, satellite images, thematic maps), data on each of the countries bordering the Black Sea (http://www.blackseaweb.net/general/country.htm), lists of existing environmental programs (http://www.blackseaweb.net/general/epp.htm), list of publications from the Black Sea Environmental Programme (http://www.blackseaweb.net/publications/welcome.html), and a set of environmental links for Bulgaria, Georgia, Romania, Russia, and Ukraine (http://www.blackseaweb.net/general/links.htm). The site also contains a Demonstrator (http://www.blackseaweb.net/demonstrator/welcome.html), which allows a number of physically and geographically separate databases to be accessed remotely through a "Black Sea Web Interface."

Key words: Bulgaria, Georgia, Romania, Russia, Turkey, Ukraine, Black Sea; environment; Black Sea Web Project 


\section{Black Sea Energy Review, Georgia}

http://www.bsrec.bg/georgia/georgia.html

September 1997. 2 pages (table of contents). Links to sections of report

The Georgian energy industry is beginning to recover from the deep recession following the breakup of the former Soviet Union. This energy review includes a map and interview. The report includes energy balance data, macroeconomic profile data, energy sector organization, energy pricing, energy legislation, economic legislation, financial sector, market reforms, investment opportunities, and an energy directory.

Key words: Georgia; energy, environment, natural gas/oil, GHG/GCC, economics; European Commission, Black Sea Regional Energy Centre.

\section{The World Factbook-Georgia}

http://www.cia.gov/cia/publications/factbook/geos/gg.html

January 2000. 8 pages. Map, data

An assortment of data about Georgia under the general topics of geography, people, government, economy, communications, transportation, military, and transnational issues. Site includes some information on the economy and electricity production and use, environment, and environmental agreements.

Key words: Georgia; economics, environment, energy, international agreements; Central Intelligence Agency, U.S. Government

\section{Black Sea Environmental Programme}

http://www.dominet.com.tr/blacksea/

1996. 3 pages (home page). Links

This home page contains a series of links grouped under general topics. Some of the linked material describes the background and structure of the Black Sea Environmental Programme and the Black Sea Environmental Programme Institutional Network. Other links describe the program in 1996 and its activities that year in emergency response, pollution monitoring, biodiversity, integrated coastal zone management, fisheries, database management and geographic information system, environmental economics and investments, nongovernmental organizations, information and communication, and policy and legislation.

Key words: Black Sea, Bulgaria, Georgia, Romania, Russia, Turkey, Ukraine; environment, institutional development, international agreements; Black Sea Environmental Programme, United Nations 


\section{Strategic Action Plan for the Rehabilitation and Protection of the Black Sea}

http://www.eelink.net/ asilwildlife/blacksea.html

October 1996. 23 pages. Narrative

Site contains text of an agreement among Bulgaria, Georgia, Romania, the Russian Federation, Turkey, and Ukraine, October 30-31, 1996. EE-Link (http://www.eelink.net/) also provides access to other international agreements relating to this region.

Key words: Bulgaria, Georgia, Romania, Russia, Turkey, Ukraine, Black Sea; environment, institutional development, international agreements; EE (Environmental Education) Link

\section{Country Brief: Georgia}

http://www.eia.doe.gov/emeu/cabs/georgia.html

March 2000. 8 pages. Narrative, map, data summary, links

Site contains a description of recent economic and political developments; oil production, refining, and transportation; natural gas consumption and transportation; and generation of electricity, power shortages, and privatization of generation. The site also contains overview data on the country, economics, energy, environment, international agreements, and energy industries, as well as links to other sources of information on Georgia.

Key words: Georgia; economics, oil/natural gas, energy, international agreements; Energy Information Administration, U.S. Government

\section{International Data: Georgia}

http://www.eia.doe.gov/emeu/international/georgia.html

January 2000. 1 page. Links

Site contains links to spreadsheet energy and energy-related data for 1992-98, reported by fuel category and a country energy balance. Links are provided to other reports.

Key words: Georgia; energy, oil/natural gas, GHG/GCC; Energy Information Administration, U.S. Government

\section{Republic of Georgia}

http://www-esd.worldbank.org/ecssd/envcopg/esgeor2.html

September 1998. 3 pages. Map, narrative, data 
The site contains a country map and data on land and water use, natural resources, biodiversity, energy efficiency, $\mathrm{CO}_{2}$ emissions, and treaty participation. The key environmental problems are briefly described. Current World Bank environment and rural development projects are listed, along with country and World Bank contacts.

Key words: Georgia; environment, GHG/GCC; World Bank

\section{Black Sea Internet Node \\ http://www.grid.unep.ch/bsein/ \\ June 1999. 1 page (home page). Links}

This site contains links to information on organizations and scientists studying the Black Sea; (inter)national research projects/programs (since 1990); cruise summary reports (since 1979); Black Sea bibliography (since 1974); acronyms and abbreviations; meta level information on environmental data for the Black Sea region; selected satellite images; and Black Sea Red Data Book (flora and fauna of region). It also contains recent data sets obtained in frameworks of different international programs and copies of some historical data sets opened for public use.

Key words: Bulgaria, Georgia, Romania, Russia, Turkey, Ukraine, Black Sea; environment, international agreements; Black Sea Environment Programme

\section{Black Sea Transboundary Diagnostic Analysis}

http://www.grid.unep.ch/bsein/tda/index.htm

June 1996. 1 page (entry page). Narrative, tables, charts

The web version of the lengthy document is broken into sections accessed from the "Content" page. (Choose "Continue" on entry page.) This report represents the results of a systematic scientific analysis of the root causes of environmental degradation in the Black Sea. The document was prepared by an international team of specialists, most from institutions in the six coastal countries. The report contains information on the environmental problems and causes, major sources and reduction of pollution, fisheries, protection of endangered species and habitats, conservation area management, and sustainable development.

Key words: Bulgaria, Georgia, Romania, Russia, Turkey, Ukraine, Black Sea; environment, international agreements; Global Environmental, Facility Black Sea Environment Programme

\section{Georgia ENRIN Home}

http://www.grida.no/enrin/htmls/kazahst/index.htm

October 1998. Home page. Map, links 
Clicking on chapter headings in the November 1996 State of Environment Report generates an English version with generous use of maps, graphs and photos (http://www.parliament.ge/

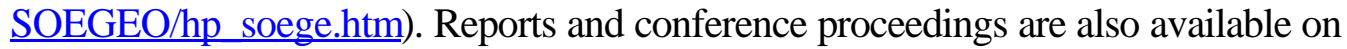
Environmental Information Systems 1995

(http://www.grida.no/enrin/htmls/georgia/age p1.htm). The Environment and Natural Resource Information Network (ENRIN) in Central and Eastern Europe and Newly Independent States home page provides links to reports on 27 countries in the region, including 25 national State of Environment Reports, 22 biodiversity reports, national contacts, regional activities, publications, and other links.

Key words: Georgia; environment, energy, institutional development; United Nations Environment Programme

\section{Facts and Figures: Environmental Data Tables}

http://www.igc.org/wri/facts/data-tables.html

March 2000. 1 page. Links

This page presents links to data tables taken from World Resources 1998-1999. These tables (in PDF format) contain information on atmosphere and climate, biodiversity, economic indicators, energy and materials, food and agriculture, forests and land cover, freshwater, health, oceans and fisheries, population and human development, and urban data.

Key words: Armenia, Azerbaijan, Bulgaria, Georgia, Kazakhstan, Romania, Russia, Turkey, Ukraine; economics, environment, energy, GHG/GCC, gas/oil, international agreements; World Resources Institute

\section{The Black Sea Economic Co-Operation and the EU}

http://www.mfa.gov.tr/grupa/percept/i3/I3-6.htm

September-November 1996. 7 pages. Narrative

Article by Ercan Özer in Perceptions: Journal of International Affairs 1(3), Center for Strategic Research, Ankara, Turkey, September-November 1997. The article argues that the European Union and the Black Sea Economic Cooperation can be mutually beneficial organizations and that there are many perspective avenues for cooperation, including the energy resources of the Black Sea area, economic reform, and ending the pollution of the Black Sea.

Key words: Bulgaria, Georgia, Romania, Russia, Turkey, Ukraine, Black Sea; economics, environment, international agreements; Center for Strategic Research 


\section{Climate Change National Agency of Georgia}

http://www.ncrc.caucasus.net/main.htm

July 2000. 1 page (home page). Links

Links are provided to country data, news, agency activities, and information about the

Convention and national communication reports. Some links are not yet operational.

Key words: Georgia; environment, GHG/GCC; Climate Change National Agency of Georgia

\section{sos}

http://www.osgf.ge/poseidon/sos.htm

http://www.osgf.ge/poseidon/sos en.htm (English)

No date given. 9 pages. Narrative, photographs

Web site, sponsored by a Georgian environmental protection group, highlights illegal fishing and capture techniques and other actions threatening biodiversity along the Georgian Black Sea coast. SOS encourages consumers to boycott illegally caught, rare, or endangered fish.

Key words: Georgia; environment; Marine Association (Poseiden)

\section{State of the Environment Georgia}

http://www.parliament.ge/SOEGEO/hp soege.htm

November 1996. 2 pages (home page). Links

The State of the Environment-Georgia report is the result of efforts to establish a national environmental information network that were initiated at the Kazbegi Workshop, Georgia, October 2-4, 1995. Representatives from different governmental agencies, scientific and development institutions, and NGOs provided data and information. On the home page, links are provided to portions of the report dealing with water and water pollution, soils, air pollution, toxic contamination, biodiversity, forest resources, the Black Sea, Kolkheti Wetlands, and mineral resources. Information is also provided on the country, environmental institutions, international cooperation, environmental education, and environmental legislation.

Key words: Georgia, Black Sea; environment, institutional development, international agreements; Georgia

\section{Caspian Sea: Four Nations Pledge Cooperation on Energy} http://www.rferl.org/nca/features/2000/05/F.RU.000522131539.html May 2000. 2 pages. Narrative 
This is a Radio Free Europe/Radio Liberty report on a May 19, 2000, seminar on energy, transportation, and security, held in Washington. There was a panel discussion that included representatives of Azerbaijan, Georgia, Kazakhstan, and Russia on the problems of getting oil and gas from the Caspian Sea-primarily the high cost of building pipelines and keeping them safe. Resolution of the conflict between Armenia and Azerbaijan would remove a major impediment development of the Caspian Sea's energy resources.

Key words: Azerbaijan, Georgia, Kazakhstan, Russia, Caspian Sea; oil/natural gas; Radio Free Europe/Radio Liberty

\section{Sustainable Development: Information on Georgia}

http://www.un.org/esa/agenda21/natlinfo/countr/georgia/index.htm

2000. 1 page. Links

This page provides links to information on four aspects of sustainable development in Georgia: social, natural resource, economic, and institutional. A series of indicators (statistical data) are provided for each aspect. More detail is provided for identified subtopics under each indicator.

Key words: Georgia; environment, institutional development, international agreements; United Nations

\section{United Nations Development Programme (UNDP) Global Environment Facility (GEF)}

http://www.undp.org/gef/portf/climeur.htm

September 2000, updated regularly. 7 pages. Table

UNDP-GEF maintains a current online portfolio of projects by country. Separate tables exist for different GEF focal areas: climate, biodiversity, international waters, and ozone depletion. Included in the portfolio tables are the country name, region, project name, project description, GEF allocation (in millions), and project type (the types are labeled as PDF- Project Development Facility; EA —Enabling Activities; PRIF—Pre-Investment Feasibility Study; FP-Full Project; MSP-Medium-size projects). The portfolio includes regional projects for both Black and Caspian Sea, as well as national projects in nearly every country of the region.

Key words: Armenia, Azerbaijan, Bulgaria, Georgia, Kazakhstan, Romania, Russia, Turkey, Ukraine, Black Sea, Caspian Sea; environment, GHG/GCC, institutional development; United Nations Development Programme 


\section{United Nations Development Programme (UNDP) National Human Development Reports}

http://www.undp.org/hdro/table.htm

August 2000, updated frequently. 5 pages. Table of available reports, links

More than 100 countries have published National Human Development Reports with UNDP support. By providing comprehensive indicators, the reports help to monitor progress and setbacks in human development and poverty at the national-level. The annual summary report for 2000 is also available online at http://www.undp.org/hdr2000/english/HDR2000.html. The 2000 Human Development Report includes a summary of national indicators such as energy use, growing urbanization, profile of environmental degradation, and access to information and communications. Each report also focuses on a highly topical theme in the current development debate, providing path-breaking analysis and policy recommendations. Individual country reports for some years are available online.

Key words: Armenia, Azerbaijan, Bulgaria, Georgia, Kazakhstan, Romania, Russia, Turkey, Ukraine; energy, environment, GHG/GCC, economics; United Nations Development Programme

\section{The Ozone Secretariat, UNEP-Nairobi, Kenya} http://www.unep.ch/ozone/

August 2000. 1 page (home page). Links

Site contains a description of the activities of the Ozone Secretariat, with links to treaties, reports, addresses, and other sites. One of the linked sites (http://www.unep.ch/ozone/ratif.htm) shows each country's signature and ratification status on agreements on the protection of the stratospheric ozone layer.

Key words: Armenia, Azerbaijan, Bulgaria, Georgia, Kazakhstan, Romania, Russia, Turkey, Ukraine; environment, GHG/GCC, international agreements; United Nations Environment Programme

\section{Georgia}

http://www.unfccc.de/resource/country/georgia.html

September 2000.1 page. Data, links 
This United Nations web page shows Georgia's status on signature and ratification of the United Nations Framework Convention and the Kyoto Protocol. Georgia has ratified both agreements. Links are provided to the initial national communication (status report), a national climate change web site, and contact points.

Key words: Georgia; environment, GHG/GCC; United Nations Framework Convention on Climate Change

\section{U.S. Agency for International Development, USAID Country Profile, Georgia http://www.usaid.gov/countries/ge/geo.htm \\ January 1997. 2 pages. Narrative, data}

Statistical summary on Georgia and an overview of USAID's strategic objectives to assist the nation with its (1) transition to democracy, (2) economic restructuring and (3) social sector/emergency humanitarian aid, primarily food and fuel.

Key words: Georgia; economics; U.S. Agency for International Development, U.S. government

\section{U.S. Agency for International Development, Program Overview, Georgia http://www.usaid.gov/country/ee/ge/}

August 2000, updated annually. 4 pages. Narrative, links

Based on annual USAID congressional presentations, an assessment of development challenges (including external debt) is presented along with an overview of U.S. assistance priorities, programs, progress, funding, and other donor activities. USAID's strategy integrates institutional and policy reform at the national level with grassroots capacity building. FY 2001 funding will support strategic objectives in enterprise growth and development, fiscal reform, private financial sector development, agribusiness, and energy sector restructuring (privatization). Details by sector-including objectives, indicators, budgets, other donors and progress to date — can be accessed through the "2001 Program/Activities" link. Links are included to additional USAID program reports, budget tables, search engine and State Department information.

Key words: Georgia; energy, economics; U.S. Agency for International Development, U.S. government

\section{U.S. Agency for International Development, FY2000 Congressional Presentation, Georgia}


http://www.usaid.gov/pubs/cp2000/eni/georgia.html

July 2000, updated annually. 20 pages. Narrative, tables

Summary of development challenges (including external debt) facing Georgia and an overview of U.S. assistance priorities, programs, progress, funding, and other donor activities. Budget tables and benchmarks and progress for each of seven strategic objectives follow the overview. The objective for a "More Economically Sustainable and Environmentally Sound Energy Sector" focuses on privatization of the energy sector and energy efficiency for industry.

Key words: Georgia; energy, economics; U.S. Agency for International Development, U.S. government

\section{Georgia-Energy Information}

http://www.worldenergy.org/wec-geis/members only/registered/open.plx?file=edc/default/ country/GEO.stm

1998. 2 pages. Narrative, data

This site includes short discussions on crude oil, liquid natural gas, and electricity. Georgia has minor oil reserves. Electrical transmission, distribution, sales, and export is state owned, but there is some private generation.

Key words: Georgia; energy, oil/natural gas; World Energy Council

\section{World Energy Council—Survey of Energy Resources, 1998}

http://www.worldenergy.org/wec-geis/publications/open.plx?file=default/current ser.htm 1998. 1 page. Table of contents, with links to each section

The 1998 survey provides an updated review of world energy resources. It reports the adequacy of the world's total energy resource base and highlights, to an increasing degree, the environmental advantages and disadvantages of each fuel, with a particular and growing emphasis on $\mathrm{CO}_{2}$ and other greenhouse gas emissions. The dominance of the main commercial fossil fuels — oil, gas, and coal—is expected to continue for the foreseeable future, with the share of natural gas increasing. Several renewable energies (e.g., solar, wind) seem to be set on the path of rapid growth and declining cost. This should see them securing competitive advantage, initially in key niche areas, before broadening in role and importance. Site includes data tables with country information.

Key words: Armenia, Azerbaijan, Bulgaria, Georgia, Kazakhstan, Romania, Russia, Turkey, Ukraine; energy, environment, oil/natural gas, GHG/GCC; World Energy Council 


\section{Georgia at a Glance: Agriculture, Natural Resources, and Environment}

http://www.wri.org/facts/cs-pdf/georgia.pdf

4 pages. Data, charts (PDF format)

This World Resources Institute fact sheet highlights data on Georgia's economic and social context; agricultural, forest, freshwater, marine, coastal, and biodiversity resources; energy and mineral resources; and involvement in international agreements. The data for these fact sheets came from the World Resources 1996-97 database, and the project was funded by the Agriculture and Natural Resource Department of the World Bank.

Key words: Georgia; economics, environment, energy, international agreements; World Resources Institute

\section{Black Sea Energy Survey}

International Energy Agency

June 2000. 256 pages

This study of the Black Sea region as a whole looks at its energy needs and how future oil and gas transport in the region could develop. It reviews the energy policies and sectors of seven countries with diverse energy situations. Azerbaijan is a major oil producer and exporter; Armenia and Georgia are energy-poor; Bulgaria and Romania are EU accession candidates which must restructure their domestic oil and coal industries; Greece and Turkey are IEA member states. This study covers energy strategies, institutions, and restructuring, as well as recent and projected energy trends in these countries. The book analyzes the reforms that are still needed to attract significant investment, both in domestic energy projects and in regional energy trade. A table of contents, sample material, and ordering information are found at http://www.iea.org/pubs/studies/files/blacksea/index.htm .

Key words: Black Sea, Armenia, Azerbaijan, Bulgaria, Georgia, Romania, Turkey; energy, oil/natural gas, economics; International Energy Agency

\section{Black Sea Voyage of Healing}

Bullfrog Films, Oley, Penn.

1998. 54-min. color video

This video chronicles a symposium on the Black Sea in Crisis, held aboard a cruise ship as it visits the countries of Georgia, Russia, Ukraine, Romania, Bulgaria, and Turkey, in a circumnavigation of the sea. The symposium was convened by the ecumenical patriarch, Bartholomew of Constantinople, of the Eastern Orthodox Church, in hopes of finding solutions 
to the problems of the Black Sea region. The participants included environmentalists, scientists, writers, and religious thinkers.

Key words: Black Sea, Bulgaria, Georgia, Romania, Russia, Turkey, Ukraine; environment; Bullfrog Films

\section{World Resources, 1998-1999}

World Resources Institute, United Nations Environment Programme, United Nations Development Programme, World Bank, Oxford University Press (USA) 1998. 384 pages. Database is also available on CD-ROM and diskette

This biennial report looks at the current state of the environment as it relates to population and human well-being, consumption and waste, and resources at risk. The book also contains country data from 157 countries and new information on poverty, inequality, and food security.

Key words: Armenia, Azerbaijan, Bulgaria, Georgia, Kazakhstan, Romania, Russia, Turkey, Ukraine; economics, environment, energy, GHG/GCC, oil/natural gas, international agreements; World Resources Institute

\section{KAZAKHSTAN}

\section{Kazakhstan and Oil}

http://www.american.edu/projects/mandala/TED/kazakh.htm

1995. 8 pages. Narrative

Kazakhstan has been active in recruiting and negotiating with oil companies to exploit its large oil reserves. Developing pipelines to transport the oil has many challenges. Threats to the environment include heavy tanker traffic through the Dardanelles Straits and flooding of the refineries due to the rise in the Caspian Sea.

Key words: Kazakhstan, Caspian Sea; oil/natural gas, environment; American University

\section{Kazakhstan}

http://www.caspianenvironment.org/kazinfo.htm

2000. 8 pages. Map, data

This site provides background information on Kazakhstan. Kazakhstan, the second largest of the former Soviet republics in territory, has enormous untapped fossil fuel reserves, plentiful supplies of other minerals and metals, and considerable agricultural potential. The site contains 
data on geography, environment, population, government, economy (including electrical production), communications, transportation, military, and transnational issues.

Key words: Kazakhstan; economics, environment, environment, energy, international agreements; Caspian Environment Programme

\section{Caspian Environment Programme}

http://www.caspianenvironment.org/second.htm

2000. 1 page (home page). Links

The Caspian Environment Programme is a regional umbrella program established by the states bordering the Caspian Sea and aided by the international agencies. A 1998 concept paper (http://www.caspianenvironment.org/concept.htm) provides the basis for the program. Links are provided to current projects, technical publications, and other sites with data, projects, and supporting organizations.

Key words: Azerbaijan, Kazakhstan, Caspian Sea; environment, international agreements; Caspian Environmental Programme

\section{The World Factbook-Kazakhstan}

http://www.cia.gov/cia/publications/factbook/geos/kz.html

January 2000. 9 pages. Map, data

The site contains an assortment of data about Kazakhstan under the general topics of geography, people, government, economy, communications, transportation, military, and transnational issues. Site includes some information on the economy and electricity production and use, environment, and environmental agreements.

Key words: Kazakhstan; economics, environment, energy, international agreements; Central Intelligence Agency, U.S. government

\section{Country Brief: Caspian Sea Region}

http://www.eia.doe.gov/emeu/cabs/caspian.html

June 2000. 5 pages. Narrative, map, links to related sites

http://www.eia.doe.gov/emeu/cabs/caspfull.html approx 30-page, more detailed report, with tables

The site discusses the oil and gas reserves in the Caspian Sea regions, and issues and options for export routes, including those that impact Bulgaria, Georgia, Romania, Russia, Turkey, 
Ukraine, and the Black Sea. There is also a discussion of environmental issues affecting the Caspian Sea: oil pollution, waste discharges, sea rise, environmental legislation, and outlook for 21st century.

Key words: Azerbaijan, Bulgaria, Kazakhstan, Romania, Russia, Turkey, Ukraine, Black Sea, Caspian Sea; oil/natural gas, energy, environment, institutional development, international agreements; Energy Information Administration, U.S. government

\section{International Data: Kazakhstan}

http://www.eia.doe.gov/emeu/international/kazak.html

January 2000. 1 page. Links

Site contains links to spreadsheet energy and energy-related data for 1992-98, reported by fuel category, and a country energy balance. Links are provided to other reports.

Key words: Kazakhstan; energy, oil/natural gas, GHG/GCC; Energy Information Administration, U.S. government

\section{Kazakhstan}

http://www-esd.worldbank.org/ecssd/envcopg/eskaza.html

September 1998. 4 pages. Map, narrative, data

The site contains a country map, data on land and water use, natural resources, biodiversity, energy efficiency, $\mathrm{CO}_{2}$ emissions, and treaty participation. The key environmental problems are briefly described. Current World Bank environment and rural development projects are listed, along with country and World Bank contacts.

Key words: Kazakhstan; environment, GHG/GCC; World Bank

\section{An Energy Overview of the Republic of Kazakhstan}

http://www.fe.doe.gov/international/kazkover.html

September 2000. 9 pages. Narrative, data

This site summarizes the energy status of the Republic of Kazakstan. Kazakstan's lack of oil and gas pipelines keeps it from making full use of its oil and gas reserves. The overview considers production and consumption of oil, natural gas, and coal, as well as nuclear power and energy infrastructure. Current electricity generation and planned generation capacity are summarized. The site briefly discusses environmental concerns, carbon dioxide, emissions, and economic conditions. 
Key words: Kazakhstan; energy, oil/natural gas, economic, environment, GHG/GCC, international agreements; U.S. Department of Energy, U.S. government

\section{State of the Biodiversity of the Republic of Kazakhstan}

http://www.grida.no/enrin/biodiv/biodiv/national/kazakh/nav/index.htm

2000. 1 page (contents). Links

This page contains links to sections of the biodiversity report. The linked material includes descriptions species and ecosystem diversity, human influence, and conservation of biodiversity. The goals of the national strategy for protecting biodiversity are also discussed. A link is provided to descriptions of native species.

Key words: Kazakhstan; environment, institutional development, international agreement; National Environmental Center for Sustainable Development of the Republic of Kazakhstan

\section{Kazakhstan ENRIN Home}

http://www.grida.no/enrin/htmls/kazahst/index.htm

October 1998. Home page, map, links.

Reports on the State of Environment (1998, includes maps) (http://www.grida.no/enrin/htmls/ kazahst/soe/index.htm) and Environmental Information Systems 1996 (http://www.grida.no/ enrin/htmls/kazahst/kazakh e.htm) are available for Kazakhstan. The Environment and Natural Resource Information Network (ENRIN) in Central and Eastern Europe and Newly Independent States (CEE/NIS) home page provides direct links to reports on 27 countries in the region, including 25 national State of Environment Reports, national contacts, regional activities, publications and other links.

Key words: Kazakhstan; environment, energy, institutional development; United Nations Environment Programme

\section{Key Energy Indicators for Kazakhstan}

http://www.iea.org/stats/files/selstats/keyindic/nmc/kazak.htm

1997. 2 pages. Data, chart, map, links

Key energy indicators are presented in a table. Data include population, GDP, energy supply, and electricity consumption. Energy supply and electricity consumption are also shown per capita and per GDP. The chart shows the portion of total energy production by fuel. Links to more detailed information are provided. 
Key words: Kazakhstan; energy, economics; International Energy Agency

\section{Facts and Figures: Environmental Data Tables}

http://www.igc.org/wri/facts/data-tables.html

March 2000. 1 page. Links

This page presents links to data tables taken from World Resources 1998-1999. These tables (in PDF format) contain information on atmosphere and climate, biodiversity, economic indicators, energy and materials, food and agriculture, forests and land cover, freshwater, health, oceans and fisheries, population and human development, and urban data.

Key words: Armenia, Azerbaijan, Bulgaria, Georgia, Kazakhstan, Romania, Russia, Turkey, Ukraine; economics, environment, energy, GHG/GCC, gas/oil, international agreements; World Resources Institute

\section{Caspian Sea: Four Nations Pledge Cooperation on Energy} http://www.rferl.org/nca/features/2000/05/F.RU.000522131539.html May 2000. 2 pages. Narrative

This is a Radio Free Europe/Radio Liberty report on a May 19, 2000, seminar on energy, transportation, and security, held in Washington. There was a panel discussion that included representatives of Azerbaijan, Georgia, Kazakhstan, and Russia on the problems of getting oil and gas from the Caspian Sea-primarily the high cost of building pipelines and keeping them safe. Resolution of the conflict between Armenia and Azerbaijan would remove a major impediment development of the Caspian Sea's energy resources.

Key words: Azerbaijan, Georgia, Kazakhstan, Russia, Caspian Sea; oil/natural gas; Radio Free Europe/Radio Liberty 


\section{Sustainable Development: Information on Kazakhstan}

http://www.un.org/esa/agenda21/natlinfo/countr/kazakh/index.htm

2000. 1 page. Links

This page provides links to information on four aspects of sustainable development in Kazakhstan: social, natural resource, economic, and institutional. A series of indicators (statistical data) are provided for each aspect. More detail is provided for identified subtopics under each indicator.

Key words: Kazakhstan; environment, GHG/GCC, institutional development, international agreements; United Nations

\section{United Nations Development Programme (UNDP) Global Environment Facility (GEF)}

http://www.undp.org/gef/portf/climeur.htm

September 2000, updated regularly. 7 pages. Table

UNDP-GEF maintains a current online portfolio of projects by country. Separate tables exist for different GEF focal areas: climate, biodiversity, international waters, and ozone depletion. Included in the portfolio tables are the country name, region, project name, project description, GEF allocation (in millions), and project type (the types are labeled as PDF- Project Development Facility; EA_Enabling Activities; PRIF_-Pre-Investment Feasibility Study; FP-Full Project; MSP_-Medium-size projects). The portfolio includes regional projects for both Black and Caspian Sea, as well as national projects in nearly every country of the region.

Key words: Armenia, Azerbaijan, Bulgaria, Georgia, Kazakhstan, Romania, Russia, Turkey, Ukraine, Black Sea, Caspian Sea; environment, GHG/GCC, institutional development; United Nations Development Programme

\section{United Nations Development Programme (UNDP) National Human Development Reports \\ http://www.undp.org/hdro/table.htm}

August 2000, updated frequently. 5 pages. Table of available reports, links

More than 100 countries have published National Human Development Reports with UNDP support. By providing comprehensive indicators, the reports help to monitor progress and setbacks in human development and poverty at the national-level. The annual summary report for 2000 is also available online at http://www.undp.org/hdr2000/english/HDR2000.html. The 2000 Human Development Report includes a summary of national indicators such as energy use, growing urbanization, profile of environmental degradation, and access to information and communications. Each report also focuses on a highly topical theme in the current development 
debate, providing path-breaking analysis and policy recommendations. Individual country reports for some years are available online.

Key words: Armenia, Azerbaijan, Bulgaria, Georgia, Kazakhstan, Romania, Russia, Turkey, Ukraine; energy, environment, GHG/GCC, economics; United Nations Development

Programme

\section{The Ozone Secretariat, UNEP-Nairobi, Kenya}

http://www.unep.ch/ozone/

August 2000. 1 page (home page). Links

Site contains a description of the activities of the Ozone Secretariat, with links to treaties, reports, addresses, and other sites. One of the linked sites (http://www.unep.ch/ozone/ratif.htm) shows each country's signature and ratification status on agreements on the protection of the stratospheric ozone layer.

Key words: Armenia, Azerbaijan, Bulgaria, Georgia, Kazakhstan, Romania, Russia, Turkey, Ukraine; environment, GHG/GCC, international agreements; United Nations Environment Programme

\section{Kazakhstan}

http://www.unfccc.de/resource/country/kaz.html

September 2000.1 page. Data, links

This United Nations web page shows Kazakhstan's status on signature and ratification of the United Nations Framework Convention. Kazakhstan has ratified the Framework Convention and signed the Kyoto Protocol. Links are provided to the initial national communication (status report) and contact points.

Key words: Kazakhstan; environment, GHG/GCC; United Nations Framework Convention on Climate Change

\section{USAID Country Profile: Kazakhstan}

http://www.usaid.gov/countries/kz/kaz.htm

October 1996. 2 pages. Narrative, data

Statistical summary on Kazakhstan with an overview of the U.S. Agency for International Development's strategic objectives to assist the nation with its (1) democratic institutions, (2) economic reforms and private sector development, and (3) social sector restructuring. 
Key words: Kazakhstan; economics; U.S. Agency for International Development, U.S. government

\section{U.S. Agency for International Development, USAID Kazakhstan}

http://www.usaid.gov/country/ee/kz/

September 2000, updated annually. 3 pages. Links

An overview of U.S. assistance priorities in Kazakhstan, discussing the political setting, development challenges and other donor activities. U.S. priorities include support for economic growth (fiscal and financial market reforms, private enterprise development), civil society, information dissemination (including public exposure of corruption), and health reform. Details by sector on objectives, indicators, progress, and funding can be accessed through the "2001 Program/Activities" link.

Key words: Kazakhstan; economics; U.S. Agency for International Development, U.S. government

\section{USAID, FY 2000 Congressional Presentation, Kazakhstan}

http://www.usaid.gov/pubs/cp2000/eni/kazak.html

July 2000, updated annually. 20 pages. Narrative, tables

Summary of development challenges facing Kazakhstan and U.S. Agency for International Developments's program to address them. Includes FY 2000 budget tables and descriptions for democracy, private enterprise, and social assistance programs.

Key words: Kazakhstan; economics; U.S. Agency for International Development, U.S. government

\section{World Energy Efficiency Association (WEEA)}

http://www.weea.org/Start.htm

2000. 1 page (home page). Links

WEEA is nonprofit organization composed of institutions and individuals charged with increasing energy efficiency around the world. It is a clearinghouse for information on energy efficiency programs, technologies, and measures. Links include the following: Energy Efficiency News, International Directory; Energy Efficiency on Web; Reports; Regional Information; and Energy Efficiency Message Posting Board. Among case studies are a report on energy efficiency for district heating projects in Kazakhstan and Kyrgyzstan. 
Key words: Kazakhstan; energy, environment; World Energy Efficiency Agency

\section{Kazakhstan-Energy Information}

http://www.worldenergy.org/wec-geis/members only/registered/open.plx?file=edc/default/

country/KAZ.stm

1998. 7 pages. Narrative, data

This site includes short discussions on crude oil and liquid natural gas, natural gas, uranium, nuclear, downstream gas, downstream oil, upstream oil and gas, and electricity. Kazakhstan has significant oil and gas resources, both onshore and offshore in the Caspian Sea. Although Kazakhstan has $17.4 \%$ of the global uranium resources, its one small nuclear plant is used primarily for desalinization and production of process heat.

Key words: Kazakhstan; energy, oil/natural gas; World Energy Council

\section{World Energy Council-Survey of Energy Resources, 1998}

http://www.worldenergy.org/wec-geis/publications/open.plx?file=default/current ser.htm 1998. 1 page. Table of contents, with links to each section

The 1998 survey provides an updated review of world energy resources. It reports the adequacy of the world's total energy resource base and highlights, to an increasing degree, the environmental advantages and disadvantages of each fuel, with a particular and growing emphasis on $\mathrm{CO}_{2}$ and other greenhouse gas emissions. The dominance of the main commercial fossil fuels — oil, gas, and coal—is expected to continue for the foreseeable future, with the share of natural gas increasing. Several renewable energies (e.g., solar, wind) seem to be set on the path of rapid growth and declining cost. This should see them securing competitive advantage, initially in key niche areas, before broadening in role and importance. Site includes data tables with country information.

Key words: Armenia, Azerbaijan, Bulgaria, Georgia, Kazakhstan, Romania, Russia, Turkey, Ukraine; energy, environment, oil/natural gas, GHG/GCC; World Energy Council 


\section{Kazakhstan at a Glance: Agriculture, Natural Resources, and Environment}

http://www.wri.org/facts/cs-pdf/kazakh.pdf

1997. 4 pages. Data, charts (PDF format)

This World Resources Institute fact sheet highlights data on Kazakhstan's economic and social context; agricultural, forest, freshwater, marine, coastal, and biodiversity resources; energy and mineral resources; and involvement in international agreements. The data for these fact sheets came from the World Resources 1996-97 database, and the project was funded by the Agriculture and Natural Resource Department of the World Bank.

Key words: Kazakhstan; economics, environment, energy, international agreements; World Resources Institute

\section{R. Cullen, "The Caspian Sea" \\ National Geographic}

May 1999. Pages 2-35. Maps, photos, narrative.

"The Soviet Union's breakup left regional economies in tatters; it also spurred the biggest oil rush of the past quarter century." This article documents the social, economic, cultural and environmental issues affecting the countries surrounding the Caspian, and its natural resources. Regional maps and keys depict such factors as income level, gas and oil reserves, landscapes, ethnolinguistic groups, oil/gas pipelines, sturgeon catch, etc.

Key words: Azerbaijan, Kazakhstan, Russia, Caspian Sea; energy, environment, economics, oil/natural gas; National Geographic Society.

\section{Caspian Oil and Gas: The Supply Potential of Central Asia and Transcaucasia International Energy Agency \\ May 1998. 297 pages}

The Caspian region has the potential to become a significant producer and exporter of oil and gas. This comprehensive study provides data on, detailed descriptions of, and analysis of the oil and gas sectors of Azerbaijan, Kazakstan, Turkmenistan and Uzbekistan. It looks at the potential for oil and gas production and exports and points out technical, legal, financial, and other barriers to fulfilling this potential. The report also examines oil and gas pipeline routes, export markets, investment frameworks and major investment projects under way and planned. A table of contents, sample content, and ordering information can be found at http://www.iea.org/pubs/studies/files/caspian/index.htm . 
Key words: Caspian Sea, Azerbaijan, Kazakhstan; energy, oil/natural gas, economics; International Energy Agency

\section{World Resources, 1998-1999}

World Resources Institute, United Nations Environment Programme, United Nations Development Programme, World Bank, Oxford University Press (USA) 1998. 384 pages. Database is also available on CD-ROM and diskette

This biennial report looks at the current state of the environment as it relates to population and human well-being, consumption and waste, and resources at risk. The book also contains country data from 157 countries and new information on poverty, inequality, and food security.

Key words: Armenia, Azerbaijan, Bulgaria, Georgia, Kazakhstan, Romania, Russia, Turkey, Ukraine; economics, environment, energy, GHG/GCC, oil/natural gas, international agreements; World Resources Institute

\section{ROMANIA}

Event: Bright Role for Innovation in the Black Sea, June 5-7, 2001 http://dbs.cordis.lu/cordis-cgi/srchidadb?ACTION=D\&SESSION=199642000-9$18 \& D O C=29 \& T B L=E N$ NEWS $\&$ RCN=EN RCN ID $15339 \& C A L L E R=E N$ UNIFIEDS $\underline{\mathrm{RCH}}$ (or search from CORDIS home page for Black Sea events)

August 2000. 1 page

The role of research and innovation in the reconstruction and development of the Black Sea Economic Community (BSEC) countries will be discussed at a forthcoming conference in Kharkov, the Ukraine, on June 5-7, 2001. Contact: email: ump@ vlink.kharkov.ua . This is an example of information available from the http://www.cordis.lu/en/home.html search system.

Key words: Black Sea, Bulgaria, Georgia, Romania, Russia, Turkey, Ukraine; economics; European Union International Scientific Cooperation

\section{Summit Declaration on Black Sea Economic Cooperation http://inter.mfa.gov.tr/grupa/af/Bsec7.HTM June 1992. 2 pages. Narrative}

This site contains the text of the summit declaration at Istanbul, June 25, 1992, agreed to by the heads of state or governments of Albania, Armenia, Azerbaijan, Bulgaria, Georgia, Greece, 
Moldova, Romania, Russia, Turkey, and Ukraine. In the text, the parties state their intention to act to improve the environment and promote economic cooperation in the region.

Key words: Armenia, Azerbaijan, Bulgaria, Georgia, Romania, Russia, Turkey, Ukraine, Black Sea; economics, international agreements; Ministry of Foreign Affairs (Republic of Turkey)

\section{Black Sea Environmental Information Center}

http://pims.ed.ornl.gov/blacksea/

2000. 1 page (home page). Links

This site provides information and training on environmental issues and problems related to the Black Sea. The web site provides information on oil spill clean-up and related commercial technologies; various countries' laws, regulations, and standards relating to the environmental condition of the Black Sea; and individuals and companies working on Black Sea environmental issues. The web site provides a real-time chat capability which enables meetings to be conducted online. There is also is an area for scientists to post scientific papers and requests for research partners. The web site is also host to a growing database of historical pollution testing data from research institutes around the Black Sea.

Key words: Bulgaria, Georgia, Romania, Russia, Turkey, Ukraine, Black Sea; environment, international agreements; U.S. Department of Energy

\section{Protocol on Protection of the Black Sea Marine Environment Against Pollution from Land Based Sources}

http://sedac.ciesin.org/pidb/texts/acrc/BlackSeaLBP.txt.html

1998 (web site). April 1992 (Convention and protocol). 7 pages. Narrative.

This protocol to the Convention on the Protection of the Black Sea against Pollution describes procedures and definitions for preventing, reducing and controlling pollution from land based sources that impact on the Black Sea. The Socioeconomic Data Applications Center (SEDAC) maintains the Center for International Earth Science Information Network (CIESIN) Environmental Treaties and Resource Indicators (ENTRI) online at http://sedac.ciesin.org/entri/. Summaries, information on status, and full text for many international treaties and conventions are available.

Key words: Bulgaria, Georgia, Romania, Russia, Black Sea; environment, international agreements; Center for International Earth Science Information Network

\section{Danube Pollution}


http://www.american.edu/projects/mandala/TED/danube.htm

1994. 7 pages. Narrative

Five major rivers and 165 million people in 17 countries contribute to the pollution of the Danube River. The river absorbs raw sewage from cities, pesticides and chemicals from farmers' fields, waste from factories, and bilge oil from ships. In a period of economic recession, most countries have not chosen to close plants to preserve the river. Romania is cited as making a significant contribution to the problem.

Key words: Bulgaria, Romania; environment; American University

\section{Black Sea Web Homepage}

http://www.blackseaweb.net/welcome.html

1999. 1 page (home page). Links

The Black Sea Web is an attempt to provide a management tool and information to assist in integrated marine environmental management of the Black Sea area. The site provides links to map sets (digital atlas, satellite images, thematic maps), data on each of the countries bordering the Black Sea (http://www.blackseaweb.net/general/country.htm), lists of existing environmental programs (http://www.blackseaweb.net/general/epp.htm), list of publications from the Black Sea Environmental Programme (http://www.blackseaweb.net/publications/welcome.html), and a set of environmental links for Bulgaria, Georgia, Romania, Russia, and Ukraine (http://www.blackseaweb.net/general/links.htm). The site also contains a Demonstrator (http://www.blackseaweb.net/demonstrator/welcome.html), which allows a number of physically and geographically separate databases to be accessed remotely through a "Black Sea Web Interface."

Key words: Bulgaria, Georgia, Romania, Russia, Turkey, Ukraine, Black Sea; environment; Black Sea Web Project

\section{Black Sea Oil, Gas, Coal Exploration and Production}

http://www.bsrec.bg/PHARE/prog95/project1/index.html

November 1998. 1 page (title page). Links to document

Although local production of oil and gas contributes only partly to the energy demand of the western Black Sea Region, the potential to develop additional production exists (to a variable degree) in each of the countries of the region. A country analysis is provided for Bulgaria and Romania. Governments are urged to modernize commercial laws, but structural changes in the government oil and gas industries and agencies, foreign investment and technology transfer are necessary for exploration and production development. Modernization and major investments 
are required to maintain or increase coal production and reduce the environmental problems created by coal mining practices in the region.

Key words: Bulgaria, Romania; energy, oil/gas; Black Sea Regional Energy Centre

\section{Black Sea Energy Review, Romania}

http://www.bsrec.bg/romania/

September 1999. 2 pages (table of contents). Links to report

In 1997 and 1998, which marked the beginning of the economy reform in Romania, the GDP decreased, but in 2000 the GDP is expected to grow by $1 \%$. This energy review includes a map and interview. The report includes energy balance data, macroeconomic profile data, energy sector organization, energy pricing, energy legislation, economic legislation, financial sector, market reforms, investment opportunities, and an energy directory. Pipeline and transmission regulations, investment laws, policy initiatives and current projects/investments are also described.

Key words: Romania; energy, environment, oil/natural gas, GHG/GCC, economics; European Commission, Black Sea Regional Energy Centre..

\section{The World Factbook-Romania}

http://www.cia.gov/cia/publications/factbook/geos/ro.html

January 2000. 8 pages. Map, data

An assortment of data about Romania under the general topics of geography, people, government, economy, communications, transportation, military, and transnational issues. Site includes some information on the economy and electricity production and use, environment, and environmental agreements.

Key words: Romania; economics, environment, energy, international agreements; Central Intelligence Agency, U.S. government

\section{OPET (Organizations for the Promotion of Energy Technologies) Home Page}

http://www.cordis.lu/opet/home.html

December 1999. 2 pages. Links to over 80 energy-related web sites worldwide

The OPET Network "aims to promote the results of new energy technologies and their introduction in society in order to improve energy efficiency and broaden the use of renewable energy sources.” Links to related sites include European Commission projects, 
Energy/Environment Research Centers, Energy Trade Associations, publications, events, success stories, and directories. One FEMOPET project focused on the Black Sea Region from 1998 to 2000 (Bulgaria/Romania). This was followed by the Black Sea Region OPET Associate Project (2000-2002, Russia, Turkey, Ukraine). Both projects, in conjunction with the Black Sea Regional Energy Centre, aimed to promote innovative renewable and conservation energy technologies.

Key words: Armenia, Azerbaijan, Black Sea, Bulgaria, Caspian Sea, Romania, Russia, Turkey, Ukraine; energy, environment, oil/natural gas, GHG/GCC, economics, international agreements, institutional development; European Commission Thermie Program

\section{Black Sea Environmental Programme}

http://www.dominet.com.tr/blacksea/

1996. 3 pages (home page). Links

This home page contains a series of links grouped under general topics. Some of the linked material describes the background and structure of the Black Sea Environmental Programme and the Black Sea Environmental Programme Institutional Network. Other links describe the program in 1996 and its activities that year in emergency response, pollution monitoring, biodiversity, integrated coastal zone management, fisheries, database management and geographic information system, environmental economics and investments, nongovernmental organizations, information and communication, and policy and legislation.

Key words: Black Sea, Bulgaria, Georgia, Romania, Russia, Turkey, Ukraine; environment, institutional development, international agreements; Black Sea Environmental Programme, United Nations

\section{Strategic Action Plan for the Rehabilitation and Protection of the Black Sea}

http://www.eelink.net/ asilwildlife/blacksea.html

October 1996. 23 pages. Narrative

Site contains text of an agreement among Bulgaria, Georgia, Romania, the Russian Federation, Turkey, and Ukraine, October 30-31, 1996. EE-Link (http://www.eelink.net/) also provides access to other international agreements relating to this region.

Key words: Bulgaria, Georgia, Romania, Russia, Turkey, Ukraine, Black Sea; environment, institutional development, international agreements; EE (Environmental Education) Link 


\section{Country Brief: Caspian-Bosporus/Black Sea Issues}

http://www.eia.doe.gov/emeu/cabs/caspblk.html

June 2000. 3 pages. Narrative

Site summarizes issues and concerns about proposed increases in shipment of oil from the Caspian Sea area through the Black Sea and the Bosporus. Impacts on Turkey, Bulgaria, Croatia, Moldova, Romania, and Ukraine are identified.

Key words: Bulgaria, Romania, Turkey, Ukraine, Black Sea, Caspian Sea; environment, oil/natural gas; Energy Information Administration, U.S. government

\section{Country Brief: Caspian Sea Region}

http://www.eia.doe.gov/emeu/cabs/caspian.html

June 2000. 5 pages. Narrative, map, links to related sites

http://www.eia.doe.gov/emeu/cabs/caspfull.html approx 30-page, more detailed report, with tables

The site discusses the oil and gas reserves in the Caspian Sea regions, and issues and options for export routes, including those that impact Bulgaria, Georgia, Romania, Russia, Turkey, Ukraine, and the Black Sea. There is also a discussion of environmental issues affecting the Caspian Sea: oil pollution, waste discharges, sea rise, environmental legislation, and outlook for 21 st century.

Key words: Azerbaijan, Bulgaria, Kazakhstan, Romania, Russia, Turkey, Ukraine, Black Sea, Caspian Sea; oil/natural gas, energy, environment, institutional development, international agreements; Energy Information Administration, U.S. government

\section{Country Brief: Romania}

http://www.eia.doe.gov/emeu/cabs/romania.html

September 1999. 9 pages. Narrative, map, data summary, links

Site contains a description of recent economic developments; oil production, refinery capacities, privatization, and transportation; consumption, refining, and transportation; natural gas production, consumption, and pipelines; and generation and transmission of electricity, including nuclear power. The site also contains overview data on the country, economics, energy, environment, international agreements, and energy industries, as well as links to other sources of information on Romania.

Key words: Romania; economics, oil/natural gas, energy, international agreements; Energy Information Administration, U.S. government 


\section{International Data: Romania}

http://www.eia.doe.gov/emeu/international/romania.html

June 2000. 1 page. Links

Site contains links to spreadsheet energy and energy-related data for 1980-98, reported by fuel category, and a country energy balance. Links are provided to other reports.

Key words: Romania; energy, oil/natural gas, GHG/GCC; Energy Information Administration, U.S. government

\section{Romania}

http://www-esd.worldbank.org/ecssd/envcopg/esroma.html

September 1998. 4 pages. Map, narrative, data

The site contains a country map, data on land and water use, natural resources, biodiversity, energy efficiency, $\mathrm{CO}_{2}$ emissions, and treaty participation. The key environmental problems are briefly described. Current World Bank environment and rural development projects are listed, along with country and World Bank contacts.

Key words: Romania; environment, GHG/GCC; World Bank

\section{An Energy Overview of Romania}

http://www.fe.doe.gov/international/romnover.htm

September 2000. 11 pages. Narrative, data

This site summarizes Romania's energy situation. Although Romania has minor oil resources, it has the largest refining industry in Central and Eastern Europe. The overview considers production and consumption of oil, natural gas, and coal. It also considers hydroelectric resources, nuclear power, and energy infrastructure. Current electricity generation and planned generation capacity are summarized. The site briefly discusses environmental concerns, $\mathrm{CO}_{2}$, emissions, and economic conditions.

Key words: Romania; energy, oil/natural gas, economic, environment, GHG/GCC, international agreements; U.S. Department of Energy, U.S. government 


\section{Black Sea Internet Node}

http://www.grid.unep.ch/bsein/

June 1999. 1 page (home page). Links

This site contains links to information on organizations and scientists studying the Black Sea; (inter)national research projects/programs (since 1990); cruise summary reports (since 1979); Black Sea bibliography (since 1974); acronyms and abbreviations; meta level information on environmental data for the Black Sea region; selected satellite images; and Black Sea Red Data Book (flora and fauna of region). It also contains recent data sets obtained in frameworks of different international programs and copies of some historical data sets opened for public use.

Key words: Bulgaria, Georgia, Romania, Russia, Turkey, Ukraine, Black Sea; environment, international agreements; Black Sea Environment Programme

\section{Black Sea Transboundary Diagnostic Analysis}

http://www.grid.unep.ch/bsein/tda/index.htm

June 1996. 1 page (entry page). Narrative, tables, charts

The web version of the lengthy document is broken into sections accessed from the "Content" page. (Choose "Continue" on entry page.) This report represents the results of a systematic scientific analysis of the root causes of environmental degradation in the Black Sea. The document was prepared by an international team of specialists, most from institutions in the six coastal countries. The report contains information on the environmental problems and causes, major sources and reduction of pollution, fisheries, protection of endangered species and habitats, conservation area management, and sustainable development.

Key words: Bulgaria, Georgia, Romania, Russia, Turkey, Ukraine, Black Sea; environment, international agreements; Global Environmental, Facility Black Sea Environment Programme

\section{Biodiversity in Romania}

http://www.grida.no/enrin/biodiv/biodiv/national/romania/

2000. 1 page (home page). Links

This page contains links to sections of the biodiversity report. The linked material includes descriptions of Romania's diversity and the threats to those species. The legal and institutional framework for biodiversity conservation and the national strategy for protecting the ecology is also discussed.

Key words: Romania; environment, institutional development, international agreement; Ministry of Waters, Forests and Environmental Protection (Romania) 


\section{Romania ENRIN Home}

http://www.grida.no/enrin/htmls/romania/index.htm

October 1998. Home page, map, links.

The State of Environment 1998 (http://nfp-ro.eionet.eu.int/soe/html/index.htm), contacts and country links are provided for Romania. The Environment and Natural Resource Information Network (ENRIN) in Central and Eastern Europe and Newly Independent States (CEE/NIS) home page provides direct links to reports on 27 countries in the region, including 25 national State of Environment Reports, 22 national reports on biodiversity, national contacts, regional activities, publications and other links.

Key words: Romania; environment, energy, institutional development; United Nations Environment Programme

\section{Key Energy Indicators for Romania}

http://www.iea.org/stats/files/selstats/keyindic/nmc/romania.htm

1997. 2 pages. Data, chart, map, links

Key energy indicators are presented in a table. Data include population, GDP, energy supply, and electricity consumption. Energy supply and electricity consumption are also shown per capita and per GDP. The chart shows the portion of total energy production by fuel. Links to more detailed information are provided.

Key words: Romania; energy, economics; International Energy Agency

\section{Facts and Figures: Environmental Data Tables}

http://www.igc.org/wri/facts/data-tables.html

March 2000. 1 page. Links

This page presents links to data tables taken from World Resources 1998-1999. These tables (in PDF format) contain information on atmosphere and climate, biodiversity, economic indicators, energy and materials, food and agriculture, forests and land cover, freshwater, health, oceans and fisheries, population and human development, and urban data.

Key words: Armenia, Azerbaijan, Bulgaria, Georgia, Kazakhstan, Romania, Russia, Turkey, Ukraine; economics, environment, energy, GHG/GCC, gas/oil, international agreements; World Resources Institute 


\section{The Black Sea Economic Co-Operation and the EU}

http://www.mfa.gov.tr/grupa/percept/i3/I3-6.htm

September-November 1996. 7 pages. Narrative

Article by Ercan Özer in Perceptions: Journal of International Affairs 1(3), Center for Strategic Research, Ankara, Turkey, September-November 1997. The article argues that the European Union and the Black Sea Economic Cooperation can be mutually beneficial organizations and that there are many perspective avenues for cooperation, including the energy resources of the Black Sea area, economic reform, and ending the pollution of the Black Sea.

Key words: Bulgaria, Georgia, Romania, Russia, Turkey, Ukraine, Black Sea; economics, environment, international agreements; Center for Strategic Research

\section{Fluxes of Greenhouse Gases in the Northwestern Region of the Black Sea Coastal Zone-Influence of the Danube River System}

http://www.nitg.tno.nl/eng/projects/3 danube/index.shtml

No date given. 1 page (first of 3 linked pages)

The site describes an ongoing project (in the second of three years) to measure greenhouse gases in natural sediments within the Danube Delta. The project aims to evaluate the contribution of gas expulsions from different parts of the delta; evaluate and model the effects of river channels and arms on gas production in shallow lakes; calculate total annual fluxes of $\mathrm{CO}_{2}, \mathrm{~N}_{2} \mathrm{O}$, and $\mathrm{CH}_{4}$ from the entire delta region; and to provide model input for predicting the changes in gas emissions due to changes in the delta morphology and ecology.

Key words: Bulgaria, Romania, Ukraine, Black Sea; GHG/GCC; Netherlands Institute of Applied Geoscience TNO-National Geological Survey

\section{Sustainable Development: Information on Romania}

http://www.un.org/esa/agenda21/natlinfo/countr/romania/index.htm

2000. 1 page (contents). Links

This page provides links to information on four aspects of sustainable development in Romania: social, natural resource, economic, and institutional. A series of indicators (statistical data) are provided for each. More detail is provided for identified subtopics under each indicator.

Key words: Romania; environment, GHG/GCC, institutional development, international agreements; United Nations 


\section{United Nations Development Programme (UNDP) Global Environment Facility (GEF)}

http://www.undp.org/gef/portf/climeur.htm

September 2000, updated regularly. 7 pages. Table

UNDP-GEF maintains a current online portfolio of projects by country. Separate tables exist for different GEF focal areas: climate, biodiversity, international waters, and ozone depletion. Included in the portfolio tables are the country name, region, project name, project description, GEF allocation (in millions), and project type (the types are labeled as PDF- Project Development Facility; EA—Enabling Activities; PRIF—Pre-Investment Feasibility Study; FP-Full Project; MSP-Medium-size projects). The portfolio includes regional projects for both Black and Caspian Sea, as well as national projects in nearly every country of the region.

Key words: Armenia, Azerbaijan, Bulgaria, Georgia, Kazakhstan, Romania, Russia, Turkey, Ukraine, Black Sea, Caspian Sea; environment, GHG/GCC, institutional development; United Nations Development Programme

\section{United Nations Development Programme (UNDP) National Human Development Reports http://www.undp.org/hdro/table.htm}

August 2000, updated frequently. 5 pages. Table of available reports, links

More than 100 countries have published National Human Development Reports with UNDP support. By providing comprehensive indicators, the reports help to monitor progress and setbacks in human development and poverty at the national-level. The annual summary report for 2000 is also available online at http://www.undp.org/hdr2000/english/HDR2000.html. The 2000 Human Development Report includes a summary of national indicators such as energy use, growing urbanization, profile of environmental degradation, and access to information and communications. Each report also focuses on a highly topical theme in the current development debate, providing path-breaking analysis and policy recommendations. Individual country reports for some years are available online.

Key words: Armenia, Azerbaijan, Bulgaria, Georgia, Kazakhstan, Romania, Russia, Turkey, Ukraine; energy, environment, GHG/GCC, economics; United Nations Development Programme 


\section{The Ozone Secretariat, UNEP-Nairobi, Kenya}

http://www.unep.ch/ozone/

August 2000. 1 page (home page). Links

Site contains a description of the activities of the Ozone Secretariat, with links to treaties, reports, addresses, and other sites. One of the linked sites (http://www.unep.ch/ozone/ratif.htm) shows each country's signature and ratification status on agreements on the protection of the stratospheric ozone layer.

Key words: Armenia, Azerbaijan, Bulgaria, Georgia, Kazakhstan, Romania, Russia, Turkey, Ukraine; environment, GHG/GCC, international agreements; United Nations Environment Programme

\section{Romania}

http://www.unfccc.de/resource/country/romania.html

September 2000. 1 page. Data, links

This United Nations web page shows Romania's status on signature and ratification of the Framework Convention. Romania has ratified the Framework Convention and signed the Kyoto Protocol. Links are provided to the first and second national communications (status reports), an in-depth review of the first national communication, and contact points.

Key words: Romania; environment, GHG/GCC; United Nations Framework Convention on Climate Change

\section{U.S. Agency for International Development, USAID Country Profile, Romania} http://www.usaid.gov/countries/ro/rom.htm

March 1996. 4 pages. Narrative, map, data

Statistical summary on Romania (1995 data) and an overview of the U.S. Agency for International Development's strategic objectives to assist the nation with (1) transition to democracy, (2) economic restructuring and (3) social stabilization.

Key words: Romania; economics; U.S. Agency for International Development, U.S. government 


\section{U.S. Agency for International Development, Program Overview, Romania http://www.usaid.gov/country/ee/ro}

August 2000, updated regularly. 3 pages. Narrative, map, links

Based on annual reports and congressional presentations, a frank assessment of development challenges (political and economic issues) is presented along with an overview of U.S. assistance priorities, programs, progress, funding, and a summary of other donor activities. In 1999, GDP fell 5\%, Romanian currency depreciated 54\%, and the informal sector represented about half of all economic activity. U.S. Agency for International Development (USAID) programs included significant support for energy-sector restructuring, environmental protection, and institutional development. Details by sector-including objectives, indicators, budgets, other donors, and progress to date — can be accessed through the "2001 Program/Activities" link. Links to additional USAID program reports, budget tables, and State Department information are included.

Key words: Romania; energy, environment; U.S. Agency for International Development, U.S. government

\section{U.S. Agency for International Development, Fact Sheet, Romania http://www.usaid.gov/press/releases/2000/fs000523 2.html}

May 2000, updated annually. 2 pages. Narrative, data

USAID assistance is summarized, including budgets for current FY 2000 ( $\$ 35$ million), the prior FY ( $\$ 55.4 \mathrm{M})$, and the next FY ( $\$ 35 \mathrm{M}$ requested), and brief descriptions of results desired from each program area: (1) promoting privatization, (2) stimulating growth of small and medium enterprises, (3) increasing environmental management, (4) building a more sustainable and environmentally sound energy sector, (5) increasing public participation, (6) promoting more effective and accountable local government, and (7) improving the welfare of women and children.

Key words: Romania; energy, environment; U.S. Agency for International Development, U.S. government

\section{Romania-Energy Information}

http://www.worldenergy.org/wec-geis/members only/registered/open.plx?file=edc/default/ country/ROM.stm

1998. 7 pages. Narrative, data, links

This site includes short discussions on the general energy economy, crude oil and liquid natural gas, uranium, nuclear, hydropower, solar energy, downstream gas, upstream oil and gas, and 
electricity. In comparison with other Eastern European countries, Romania has significant energy resources and a history of energy production and processing. Romanian indigenous production of energy has been decreasing continuously, falling to $80 \%$ of its 1990 level by 1995. Links are provided to statistical tables from the 1998 International Energy Data Report on energy supply and demand, electricity supply, and $\mathrm{CO}_{2}$ emissions and energy efficiency indications and explanatory material from the 1998 Energy Efficiency Policies and Indicators Report.

Key words: Romania; energy, oil/natural gas; World Energy Council

\section{World Energy Council-Survey of Energy Resources, 1998}

http://www.worldenergy.org/wec-geis/publications/open.plx?file=default/current ser.htm 1998. 1 page. Table of contents, with links to each section

The 1998 survey provides an updated review of world energy resources. It reports the adequacy of the world's total energy resource base and highlights, to an increasing degree, the environmental advantages and disadvantages of each fuel, with a particular and growing emphasis on $\mathrm{CO}_{2}$ and other greenhouse gas emissions. The dominance of the main commercial fossil fuels — oil, gas, and coal—is expected to continue for the foreseeable future, with the share of natural gas increasing. Several renewable energies (e.g., solar, wind) seem to be set on the path of rapid growth and declining cost. This should see them securing competitive advantage, initially in key niche areas, before broadening in role and importance. Site includes data tables with country information.

Key words: Armenia, Azerbaijan, Bulgaria, Georgia, Kazakhstan, Romania, Russia, Turkey, Ukraine; energy, environment, oil/natural gas, GHG/GCC; World Energy Council

\section{Romania at a Glance: Agriculture, Natural Resources, and Environment}

http://www.wri.org/facts/cs-pdf/romania.pdf

1997. 4 pages. Data, charts (PDF format)

This World Resources Institute fact sheet highlights data on Romania's economic and social context; agricultural, forest, freshwater, marine, coastal, and biodiversity resources; energy and mineral resources; and involvement in international agreements. The data for these fact sheets came from the World Resources 1996-97 database, and the project was funded by the Agriculture and Natural Resource Department of the World Bank.

Key words: Romania; economics, environment, energy, international agreements; World Resources Institute 


\section{Black Sea Energy Survey}

International Energy Agency

June 2000. 256 pages

This study of the Black Sea region as a whole looks at its energy needs and how future oil and gas transport in the region could develop. It reviews the energy policies and sectors of seven countries with diverse energy situations. Azerbaijan is a major oil producer and exporter; Armenia and Georgia are energy-poor; Bulgaria and Romania are EU accession candidates which must restructure their domestic oil and coal industries; Greece and Turkey are IEA member states. This study covers energy strategies, institutions, and restructuring, as well as recent and projected energy trends in these countries. The book analyzes the reforms that are still needed to attract significant investment, both in domestic energy projects and in regional energy trade. A table of contents, sample material, and ordering information are found at http://www.iea.org/pubs/studies/files/blacksea/index.htm .

Key words: Black Sea, Armenia, Azerbaijan, Bulgaria, Georgia, Romania, Turkey; energy, oil/natural gas, economics; International Energy Agency

\section{Black Sea: Voyage of Healing}

Bullfrog Films, Oley, Penn.

1998. 54-min. color video

This video chronicles a symposium on the Black Sea in Crisis, held aboard a cruise ship as it visits the countries of Georgia, Russia, Ukraine, Romania, Bulgaria, and Turkey, in a circumnavigation of the sea. The symposium was convened by the ecumenical patriarch, Bartholomew of Constantinople, of the Eastern Orthodox Church, in hopes of finding solutions to the problems of the Black Sea region. The participants included environmentalists, scientists, writers, and religious thinkers.

Key words: Black Sea, Bulgaria, Georgia, Romania, Russia, Turkey, Ukraine; environment; Bullfrog Films

\section{World Resources, 1998-1999}

World Resources Institute, United Nations Environment Programme, United Nations Development Programme, World Bank, Oxford University Press (USA) 1998. 384 pages. Database is also available on CD-ROM and diskette

This biennial report looks at the current state of the environment as it relates to population and human well-being, consumption and waste, and resources at risk. The book also contains country data from 157 countries and new information on poverty, inequality, and food security. 
Key words: Armenia, Azerbaijan, Bulgaria, Georgia, Kazakhstan, Romania, Russia, Turkey, Ukraine; economics, environment, energy, GHG/GCC, oil/natural gas, international agreements; World Resources Institute

\section{RUSSIA (RUSSIAN FEDERATION)}

Event: Bright Role for Innovation in the Black Sea, June 5-7, 2001

http://dbs.cordis.lu/cordis-cgi/srchidadb?ACTION=D\&SESSION=199642000-9$18 \& D O C=29 \&$ TBL $=$ EN NEWS \&RCN=EN RCN ID $15339 \& C A L L E R=E N$ UNIFIEDS $\underline{\mathrm{RCH}}$ (or search from CORDIS home page for Black Sea events)

August 2000. 1 page

The role of research and innovation in the reconstruction and development of the Black Sea Economic Community (BSEC) countries will be discussed at a forthcoming conference in Kharkov, the Ukraine, on June 5-7, 2001. Contact: email: ump@ vlink.kharkov.ua . This is an example of information available from the http://www.cordis.lu/en/home.html search system.

Key words: Black Sea, Bulgaria, Georgia, Romania, Russia, Turkey, Ukraine; economics; European Union International Scientific Cooperation

\section{Bosphorus Straits Regulation and Central Asian Oil}

http://gurukul.ucc.american.edu/ted/BOSPORUS.HTM

1995. 8 pages. Narrative with references

This site discusses issues surrounding the dispute over Turkish regulations for sea traffic through the straits separating the Mediterranean and Black Seas, including strategic political, environmental, and economic factors. Turkey justified the measures on environmental and safety grounds (from 1988-92 there were 155 collisions in the Straits, and about $60 \%$ of all vessels transport hazardous materials such as oil, gas, and chemicals). Russian exports of natural gas and oil were most affected and led to protests that the new regulations illegally restricted the free passage through the Straits that was guaranteed in the Montreaux Treaty of 1936.

Key words: Russia, Turkey, Black Sea; environment, energy, international agreements; American University 


\section{Summit Declaration on Black Sea Economic Cooperation http://inter.mfa.gov.tr/grupa/af/Bsec7.HTM \\ June 1992. 2 pages. Narrative}

This site contains the text of the summit declaration at Istanbul, June 25, 1992, agreed to by the heads of state or governments of Albania, Armenia, Azerbaijan, Bulgaria, Georgia, Greece, Moldova, Romania, Russia, Turkey, and Ukraine. In the text, the parties state their intention to act to improve the environment and promote economic cooperation in the region.

Key words: Armenia, Azerbaijan, Bulgaria, Georgia, Romania, Russia, Turkey, Ukraine, Black Sea; economics, international agreements; Ministry of Foreign Affairs (Republic of Turkey)

\section{Russian Energy: A Blessing and a Curse}

http://library.northernlight.com/UU20000621140019001.html?inid=fCgnPH5laTgNdgJqeh5yV wFUUUYIGB1BcAB8FABiBF0\%253D\#doc (fee for complete article)

Fall 1999. 9 pages. Narrative

Article by Marshall I. Goldman from the Journal of International Affairs 53 (1), Fall 1999, p. 73. The article contains a primarily economic discussion of how Russia's abundant energy resources have allowed the country to become an inefficient producer and user of energy.

Key words: Russia; energy, economics, oil/natural gas; Journal of International Affairs

\section{Black Sea Environmental Information Center}

http://pims.ed.ornl.gov/blacksea/

2000. 1 page (home page). Links

This site provides information and training on environmental issues and problems related to the Black Sea. The web site provides information on oil spill clean-up and related commercial technologies; various countries' laws, regulations, and standards relating to the environmental condition of the Black Sea; and individuals and companies working on Black Sea environmental issues. The web site provides a real-time chat capability which enables meetings to be conducted online. There is also is an area for scientists to post scientific papers and requests for research partners. The web site is also host to a growing database of historical pollution testing data from research institutes around the Black Sea.

Key words: Bulgaria, Georgia, Romania, Russia, Turkey, Ukraine, Black Sea; environment, international agreements; U.S. Department of Energy 


\section{Protocol on Protection of the Black Sea Marine Environment Against Pollution from Land Based Sources}

http://sedac.ciesin.org/pidb/texts/acrc/BlackSeaLBP.txt.html

1998 (web site). April 1992 (Convention and protocol). 7 pages. Narrative.

This protocol to the Convention on the Protection of the Black Sea against Pollution describes procedures and definitions for preventing, reducing and controlling pollution from land based sources that impact on the Black Sea. The Socioeconomic Data Applications Center (SEDAC) maintains the Center for International Earth Science Information Network (CIESIN) Environmental Treaties and Resource Indicators (ENTRI) online at http://sedac.ciesin.org/entri/. Summaries, information on status, and full text for many international treaties and conventions are available.

Key words: Bulgaria, Georgia, Romania, Russia, Black Sea; environment, international agreements; Center for International Earth Science Information Network

\section{Oil Consortium Agreement with Azerbaijan}

http://www.american.edu/projects/mandala/TED/azeri.htm

1996. 7 pages. Narrative

On November 20,1994, a consortium of oil companies signed a contract with the nation of Azerbaijan. The consortium believes it can extract up to 4 billion barrels of oil from three wells in the Caspian Sea. The problem is the route to be used to take the oil to the world market. The consortium plans two pipelines: a Russian route and one through Georgia to the Black Sea. The potential remains for oil spill problems from pipeline breaks or shipping mishaps.

Key words: Azerbaijan, Russia; oil/natural gas; American University

\section{Caspian Sea, Iran, and Caviar}

http://www.american.edu/projects/mandala/TED/caspian.htm

1993. 4 pages. Narrative

This paper discusses the recent political and environmental impacts on the caviar market. While Russia and Iran have traditionally been large suppliers, the pollution and increase in water levels in the Caspian Sea have threatened the supply of sturgeon and caviar. Azerbaijan, Turkmenia, Kazakhstan and Russia signed an agreement in 1992 to form an organization to exploit the Caspian marine resources.

Key words: Russia, Caspian Sea; environment; American University 


\section{Caspian Oil and Political Implications}

http://www.american.edu/projects/mandala/TED/caspoil.htm

1998. 9 pages. Narrative

Although once thought minimal, Caspian oil reserves are now considered more plentiful than Persian Gulf oil. This paper discusses the various claims on Caspian oil, and the political complications of various pipeline routes from the area. Tensions between Armenia and Azerbaijan threaten the shortest route between Baku and Turkey. Once the oil reaches the Black Sea, the most viable option is to ship it through the Bosporus. This route, however, has environmental implications because there are frequent oil leaks from tankers working their way through the narrow straits

Key words: Armenia, Azerbaijan, Russia, Georgia, Turkey, Black Sea, Caspian Sea; oil/natural gas, environment; American University

\section{Russian Air Pollution}

http://www.american.edu/projects/mandala/TED/russair.htm

1996. 7 pages. Narrative

This paper is a brief description of the pollution of the Russian air and some of the impacts of that pollution.

Key words: Russia; environment; American University

\section{Black Sea Web Homepage}

http://www.blackseaweb.net/welcome.html

1999. 1 page (home page). Links

The Black Sea Web is an attempt to provide a management tool and information to assist in integrated marine environmental management of the Black Sea area. The site provides links to map sets (digital atlas, satellite images, thematic maps), data on each of the countries bordering the Black Sea (http://www.blackseaweb.net/general/country.htm), lists of existing environmental programs (http://www.blackseaweb.net/general/epp.htm), list of publications from the Black Sea Environmental Programme (http://www.blackseaweb.net/publications/welcome.html), and a set of environmental links for Bulgaria, Georgia, Romania, Russia, and Ukraine (http://www.blackseaweb.net/general/links.htm). The site also contains a Demonstrator (http://www.blackseaweb.net/demonstrator/welcome.html), which allows a number of physically and geographically separate databases to be accessed remotely through a "Black Sea Web Interface." 
Key words: Bulgaria, Georgia, Romania, Russia, Turkey, Ukraine, Black Sea; environment; Black Sea Web Project

The Economic Debacle in Northeast Asia: Economic, Political and Social Legacies http://www.brookings.org/fp/cnaps/papers/1999 collaboration.htm

August 1999. 17 pages. Narrative

This working paper focuses on economic conditions in northeast Asia and is the result of a collaborative research project by the Center for Northeast Asian Policy Studies (CNAPS), Foreign Policy Studies. In this report, the seven authors - all policy analysts or practitioners specializing on Northeast Asia - take a critical look at the economic, political and social legacies of the crisis, and offer reasoned policy prescriptions as their governments pursue varied paths to cope with its long-term aftershocks. The seven contributing authors are Bates Gill, Alexander Huang, Masaharu Kohno, Guoqiang Long, Se-Il Park, Masabumi Suzuki, and Sergei Troush.

Key words: Russia; economics; Brookings Institute

\section{Black Sea Region OPET (Organizations for the Promotion of Energy Technologies) Associate Project}

http://www.bsrec.bg/opet/menus/background1.html

July 2000. 10 pages. Links to project activity descriptions

In May 2000, the Black Sea Regional Energy Center was awarded a project by the European Union to promote innovative renewable and conservation energy technologies, targeted to the market actors from the Black Sea: Albania, Moldova, Russia, Macedonia, Turkey, and Ukraine. The OPET Network "aims to promote the results of new energy technologies and their introduction in society in order to improve energy efficiency and broaden the use of renewable energy sources." Reports on previous OPET projects in the area can also be accessed.

Key words: Russia, Turkey, Ukraine, Black Sea; energy, environment; Black Sea Regional Energy Centre

\section{Black Sea Energy Review, Russia}

http://www.bsrec.bg/russia/index.html

November 1998. 2 pages (table of contents). Links to report 
The Russian Federation is one of the leading energy-producing and energy-consuming countries in the world. Russian oil production is $13 \%$ of the world total, while its gas production accounts for about $31 \%$ of the world total. The reduction in overall economic activity and the switch to a more service-oriented economy have also reduced national energy demand. This energy review includes a map and interview. The report includes energy balance data, macroeconomic profile data, energy sector organization, energy pricing, energy legislation, economic legislation, financial sector, market reforms, investment opportunities,. and an energy directory. (At this time, only the summary appears to be online.)

Key words: Russia; energy, environment, oil/natural gas, GHG/GCC, economics; European Commission, Black Sea Regional Energy Centre.

\section{The World Factbook-Russia}

http://www.cia.gov/cia/publications/factbook/geos/rs.html

January 2000. 10 pages. Map, data

An assortment of data about Russia under the general topics of geography, people, government, economy, communications, transportation, military, and transnational issues. Site includes some information on the economy and electricity production and use, environment, and environmental agreements.

Key words: Russia; economics, environment, energy, international agreements; Central Intelligence Agency, U.S. government

\section{OPET (Organizations for the Promotion of Energy Technologies) Home Page} http://www.cordis.lu/opet/home.html

December 1999. 2 pages. Links to over 80 energy-related web sites worldwide

The OPET Network "aims to promote the results of new energy technologies and their introduction in society in order to improve energy efficiency and broaden the use of renewable energy sources." Links to related sites include European Commission projects, Energy/Environment Research Centers, Energy Trade Associations, publications, events, success stories, and directories. One FEMOPET project focused on the Black Sea Region from 1998 to 2000 (Bulgaria/Romania). This was followed by the Black Sea Region OPET Associate Project (2000-2002, Russia, Turkey, Ukraine). Both projects, in conjunction with the Black Sea Regional Energy Centre, aimed to promote innovative renewable and conservation energy technologies. 
Key words: Armenia, Azerbaijan, Black Sea, Bulgaria, Caspian Sea, Romania, Russia, Turkey, Ukraine; energy, environment, oil/natural gas, GHG/GCC, economics, international agreements, institutional development; European Commission Thermie Program

\section{Black Sea Environmental Programme \\ http://www.dominet.com.tr/blacksea/ \\ 1996. 3 pages (home page). Links}

This home page contains a series of links grouped under general topics. Some of the linked material describes the background and structure of the Black Sea Environmental Programme and the Black Sea Environmental Programme Institutional Network. Other links describe the program in 1996 and its activities that year in emergency response, pollution monitoring, biodiversity, integrated coastal zone management, fisheries, database management and geographic information system, environmental economics and investments, nongovernmental organizations, information and communication, and policy and legislation.

Key words: Black Sea, Bulgaria, Georgia, Romania, Russia, Turkey, Ukraine; environment, institutional development, international agreements; Black Sea Environmental Programme

\section{Strategic Action Plan for the Rehabilitation and Protection of the Black Sea http://www.eelink.net/ asilwildlife/blacksea.html \\ October 1996. 23 pages. Narrative}

Site contains text of an agreement among Bulgaria, Georgia, Romania, the Russian Federation, Turkey, and Ukraine, October 30-31, 1996. EE-Link (http://www.eelink.net/) also provides access to other international agreements relating to this region.

Key words: Bulgaria, Georgia, Romania, Russia, Turkey, Ukraine, Black Sea; environment, institutional development, international agreements; EE (Environmental Education) Link

\section{Country Brief: Caspian Sea Region}

http://www.eia.doe.gov/emeu/cabs/caspian.html

June 2000. 5 pages. Narrative, map, links to related sites

http://www.eia.doe.gov/emeu/cabs/caspfull.html approx 30-page, more detailed report, with tables

The site discusses the oil and gas reserves in the Caspian Sea regions, and issues and options for export routes, including those that impact Bulgaria, Georgia, Romania, Russia, Turkey, Ukraine, and the Black Sea. There is also a discussion of environmental issues affecting the 
Caspian Sea: oil pollution, waste discharges, sea rise, environmental legislation, and outlook for 21 st century.

Key words: Azerbaijan, Bulgaria, Kazakhstan, Romania, Russia, Turkey, Ukraine, Black Sea, Caspian Sea; oil/natural gas, energy, environment, institutional development, international agreements; Energy Information Administration, U.S. government

\section{Russian Oil and Gas Exports Fact Sheet}

http://www.eia.doe.gov/emeu/cabs/rusexp.html

July 1999. 3 pages. Narrative, chart, links

Site contains information on Russian petroleum and natural gas exports within and outside the former Soviet Union from 1990 to 1998.

Key words: Russia; energy, oil/natural gas; Energy Information Administration, U.S. government

\section{Country Brief: Russia}

http://www.eia.doe.gov/emeu/cabs/russia.html

http://www.eia.doe.gov/emeu/cabs/russfull.html (a 14-page, more detailed version of the same report)

February 2000. 10 pages. Narrative, map, data summary, charts, links

Site contains a description of recent economic developments; oil production, exports, refining, and related issues; natural gas production and exports; coal mining; generation of electricity (including nuclear power plants); renewable energy sources, and environmental issues. The site also contains overview data on the country, economics, energy, environment, and oil and gas, as well as links to other sources of information on Russia.

Key words: Russia; economics, oil/natural gas, energy, environment, international agreements; Energy Information Administration, U.S. government

\section{Russia: Environmental Issues}

http://www.eia.doe.gov/emeu/cabs/russenv.html

December 1999. 4 pages. Narrative, charts

Site focuses on environmental issues in Russia, resulting from air and water pollution due to increasing numbers of automobiles, aging industrial sites, and the Chernobyl nuclear accident. 
Site includes short discussions of air pollution, energy use and carbon emissions, energy and carbon intensity, per capita carbon emissions, nuclear waste, and outlook for the 21 st century.

Key words: Russia; environment, greenhouse gases, energy; Energy Information

Administration, U.S. government

\section{International Data: Russia}

http://www.eia.doe.gov/emeu/international/russia.html

May 2000. 1 page. Links

Site contains links to spreadsheet energy and energy-related data for 1992-98, reported by fuel category, a country energy balance, and historical crude oil prices and crude oil production figures. Links are provided to other reports.

Key words: Russia; energy, oil/natural gas, GHG/GCC; Energy Information Administration, U.S. government

\section{Russian Federation}

http://www-esd.worldbank.org/ecssd/envcopg/esruss.html

September 1998. 3 pages. Map, narrative, data

The site contains a country map, data on land and water use, natural resources, biodiversity, energy efficiency, $\mathrm{CO}_{2}$ emissions, and treaty participation. The key environmental problems are briefly described. Current World Bank environment and rural development projects are listed, along with country and World Bank contacts.

Key words: Russia; environment, GHG/GCC; World Bank

\section{Russia Meets Resistance in Plans for New Black Sea Terminal}

http://www.gasandoil.com/goc/news/ntr74832.htm

November 1997. 1 page. Narrative

Article from Alexander's Gas and Oil Connections News and Trends, CIS/Russia 3 (26), November 25, 1997, describing environmentalists' opposition to a new oil terminal in an undeveloped area of the Russian Black Sea coast.

Key words: Russia; environment, oil/natural gas; Alexander's Oil and Gas Connections

\section{Black Sea Internet Node}


http://www.grid.unep.ch/bsein/

June 1999. 1 page (home page). Links

This site contains links to information on organizations and scientists studying the Black Sea; (inter)national research projects/programs (since 1990); cruise summary reports (since 1979); Black Sea bibliography (since 1974); acronyms and abbreviations; meta level information on environmental data for the Black Sea region; selected satellite images; and Black Sea Red Data Book (flora and fauna of region). It also contains recent data sets obtained in frameworks of different international programs and copies of some historical data sets opened for public use.

Key words: Bulgaria, Georgia, Romania, Russia, Turkey, Ukraine, Black Sea; environment, international agreements; Black Sea Environment Programme

\section{Black Sea Transboundary Diagnostic Analysis}

http://www.grid.unep.ch/bsein/tda/index.htm

June 1996. 1 page (entry page). Narrative, tables, charts

The web version of the lengthy document is broken into sections accessed from the "Content" page. (Choose "Continue" on entry page.) This report represents the results of a systematic scientific analysis of the root causes of environmental degradation in the Black Sea. The document was prepared by an international team of specialists, most from institutions in the six coastal countries. The report contains information on the environmental problems and causes, major sources and reduction of pollution, fisheries, protection of endangered species and habitats, conservation area management, and sustainable development.

Key words: Bulgaria, Georgia, Romania, Russia, Turkey, Ukraine, Black Sea; environment, international agreements; Global Environmental, Facility Black Sea Environment Programme

\section{Biodiversity in Russian Federation}

http://www.grida.no/enrin/biodiv/biodiv/national/russial

2000. 1 page (home page). Links

The web page links to sections describing the vast biodiversity in the Russian Federation, factors impacting biodiversity, lists of species, and changes. Other useful links and information sources are included.

Key words: Russia; environment; Russian Federation on Environmental Protection

\section{Russian ENRIN Home}


http://www.grida.no/enrin/htmls/russia/index.htm

June 1998. Home page, map, links.

The extensive annual State of Environment Report is available in English through the ENRIN or Russian GRID home (http://grid.ecoinfo.ru/webint eng/start.htm) which provides access to additional documents in English and Russian, as well as the Meta Data Directory (http://grid.ecoinfo.ru/eng mdd/defaultmdd.htm) on protected areas, territorial agencies and other organizations. The Environment and Natural Resource Information Network (ENRIN) in Central and Eastern Europe and Newly Independent States home page provides links to reports on 27 countries in the region, including 25 national State of Environment Reports, 22 biodiversity reports, national contacts, regional activities, publications and other links.

Key words: Russia; environment, energy, institutional development; United Nations Environment Programme

\section{Key Energy Indicators for Russia}

http://www.iea.org/stats/files/selstats/keyindic/nmc/russia.htm

1997. 2 pages. Data, chart, map, links

Key energy indicators are presented in a table. Data include population, GDP, energy supply, and electricity consumption. Energy supply and electricity consumption are also shown per capita and per GDP. The chart shows the portion of total energy production by fuel. Links to more detailed information are provided.

Key words: Russia; energy, economics; International Energy Agency

\section{Facts and Figures: Environmental Data Tables}

http://www.igc.org/wri/facts/data-tables.html

March 2000. 1 page. Links

This page presents links to data tables taken from World Resources 1998-1999. These tables (in PDF format) contain information on atmosphere and climate, biodiversity, economic indicators, energy and materials, food and agriculture, forests and land cover, freshwater, health, oceans and fisheries, population and human development, and urban data.

Key words: Armenia, Azerbaijan, Bulgaria, Georgia, Kazakhstan, Romania, Russia, Turkey, Ukraine; economics, environment, energy, GHG/GCC, gas/oil, international agreements; World Resources Institute 


\section{The Black Sea Economic Co-Operation and the EU}

http://www.mfa.gov.tr/grupa/percept/i3/I3-6.htm

September-November 1996. 7 pages. Narrative

Article by Ercan Özer in Perceptions: Journal of International Affairs 1(3), Center for Strategic Research, Ankara, Turkey, September-November 1997. The article argues that the European Union and the Black Sea Economic Cooperation can be mutually beneficial organizations and that there are many perspective avenues for cooperation, including the energy resources of the Black Sea area, economic reform, and ending the pollution of the Black Sea.

Key words: Bulgaria, Georgia, Romania, Russia, Turkey, Ukraine, Black Sea; economics, environment, international agreements; Center for Strategic Research

\section{Turkey: Black Sea Pollution Depletes Fishing Stocks}

http://www.rferl.org/nca/features/1998/11/F.RU.981103134427.html

November 1998. 2 pages Narrative

Text of radio report by Jolyon Naegele discussing the pollution of the Black Sea. While much of the pollution comes from other countries, Turkey has been impacted by the severe depletion of the fishing stock. Some species have died off, and the stocks of other species have been greatly reduced.

Key words: Russia, Turkey, Black Sea; environment; Radio Free Europe-Radio Liberty

\section{Caspian Sea: Four Nations Pledge Cooperation on Energy} http://www.rferl.org/nca/features/2000/05/F.RU.000522131539.html May 2000. 2 pages. Narrative

This is a Radio Free Europe/Radio Liberty report on a May 19, 2000, seminar on energy, transportation, and security, held in Washington. There was a panel discussion that included representatives of Azerbaijan, Georgia, Kazakhstan, and Russia on the problems of getting oil and gas from the Caspian Sea-primarily the high cost of building pipelines and keeping them safe. Resolution of the conflict between Armenia and Azerbaijan would remove a major impediment development of the Caspian Sea's energy resources.

Key words: Azerbaijan, Georgia, Kazakhstan, Russia, Caspian Sea; oil/natural gas; Radio Free Europe/Radio Liberty

\section{Sustainable Development: Information on Russian Federation}


http://www.un.org/esa/agenda21/natlinfo/countr/russia/index.htm

2000. 1 page. Links

This page provides links to information on four aspects of sustainable development in the Russian Federation: social, natural resource, economic, and institutional. A series of indicators (statistical data) are provided for each. More detail is provided for identified subtopics under each indicator.

Key words: Russia; environment, GHG/GCC, institutional development, international agreements; United Nations

\section{United Nations Development Programme (UNDP) Global Environment Facility (GEF)}

http://www.undp.org/gef/portf/climeur.htm

September 2000, updated regularly. 7 pages. Table

UNDP-GEF maintains a current online portfolio of projects by country. Separate tables exist for different GEF focal areas: climate, biodiversity, international waters, and ozone depletion. Included in the portfolio tables are the country name, region, project name, project description, GEF allocation (in millions), and project type (the types are labeled as PDF- Project Development Facility; EA_-Enabling Activities; PRIF_-Pre-Investment Feasibility Study; FP_Full Project; MSP_-Medium-size projects). The portfolio includes regional projects for both Black and Caspian Sea, as well as national projects in nearly every country of the region.

Key words: Armenia, Azerbaijan, Bulgaria, Georgia, Kazakhstan, Romania, Russia, Turkey, Ukraine, Black Sea, Caspian Sea; environment, GHG/GCC, institutional development; United Nations Development Programme

\section{United Nations Development Programme (UNDP) National Human Development Reports}

http://www.undp.org/hdro/table.htm

August 2000, updated frequently. 5 pages. Table of available reports, links

More than 100 countries have published National Human Development Reports with UNDP support. By providing comprehensive indicators, the reports help to monitor progress and setbacks in human development and poverty at the national-level. The annual summary report for 2000 is also available online at http://www.undp.org/hdr2000/english/HDR2000.html. The 2000 Human Development Report includes a summary of national indicators such as energy use, growing urbanization, profile of environmental degradation, and access to information and communications. Each report also focuses on a highly topical theme in the current development 
debate, providing path-breaking analysis and policy recommendations. Individual country reports for some years are available online.

Key words: Armenia, Azerbaijan, Bulgaria, Georgia, Kazakhstan, Romania, Russia, Turkey, Ukraine; energy, environment, GHG/GCC, economics; United Nations Development Programme

\section{The Ozone Secretariat, UNEP-Nairobi, Kenya} http://www.unep.ch/ozone/

August 2000. 1 page (home page). Links

Site contains a description of the activities of the Ozone Secretariat, with links to treaties, reports, addresses, and other sites. One of the linked sites (http://www.unep.ch/ozone/ratif.htm) shows each country's signature and ratification status on agreements on the protection of the stratospheric ozone layer.

Key words: Armenia, Azerbaijan, Bulgaria, Georgia, Kazakhstan, Romania, Russia, Turkey, Ukraine; environment, GHG/GCC, international agreements; United Nations Environment Programme

\section{Russian Federation}

http://www.unfccc.de/resource/country/rf.html

September 2000. 1 p., data, links

This United Nations web page shows the Russian Federation's status on signature and ratification of the United Nations Framework Convention. The Russian Federation has ratified the Framework Convention and signed the Kyoto Protocol. Links are provided to the first national communications (status report), an in-depth review of the first national communication, and contact points.

Key words: Russia; environment, GHG/GCC; United Nations Framework Convention on Climate Change

\section{U.S. Agency for International Development, USAID Country Profile, Russia http://www.usaid.gov/countries/ru/rus.htm}


October 1996. 2 pages. Narrative, data

The Russian Federation contains " $30 \%$ of the world's natural gas reserves, $20 \%$ of coal, $20 \%$ of gold, $6 \%$ of oil, abundant uranium, diamonds, copper, lead and silver, and one quarter of the world's forests." Narrative presentation of political and economic issues and USAID's strategic objectives (1996) to assist the nation with its (1) transition to democracy, (2)economic restructuring, and (3) social sector restructuring.

Key words: Russia; economics; U.S. Agency for International Development, U.S. government

\section{U.S. Agency for International Development, Program Overview, Russia} http://www.usaid.gov/country/ee/ru/

August 2000, updated annually. 4 pages. Narrative, links

Based on annual U.S. Agency for International Development's (USAID) Congressional presentations, an assessment of development challenges (including $\$ 150$ billion external debt burden) is presented along with an overview of U.S. assistance priorities, programs, progress, and other donor activities. USAID now emphasizes partnerships with civil society and interventions at the regional level (Far East, Samara, Novgorod, and Tomskto) to implement programs for broad-based economic growth, democratic transition, and improved effectiveness of health and other social safety net services. Details by sector-including objectives, indicators, budgets, other donors, and progress to date — can be accessed through the "FY2001 Program Activities" link. The environmental objectives include biodiversity protection, economic incentives for sound resource management, and increased capacity to deal with environmental pollution. Links are provided to additional USAID program reports, budget tables, a search engine, and State Department information.

Key words: Russia; environment, economics; U.S. Agency for International Development, U.S. government

\section{U.S. Agency for International Development, FY 2000 Congressional Presentation, Russia \\ http://www.usaid.gov/pubs/cp2000/eni/russia.html \\ July 2000, updated annually. 26 pages. Narrative, data}

This site presents a summary of development challenges (including external debt) facing Russia and an overview of U.S. assistance priorities, programs, progress, and funding (\$172M in 1999 and $\$ 295 \mathrm{M}$ requested for 2000 ). It then provides more detailed descriptions, funding, benchmarks, and progress for each of six strategic objective areas. The environmental 
objectives are to address pollution as a threat to public health and to improve natural resources management, environmental protection, and emissions trading.

Key words: Russia; energy, economics; U.S. Agency for International Development, U.S. government

\section{USAID, Reducing the Threat of Global Climate Change}

http://www.usaid.gov/environment/climate change.html

1999. 2 pages (home page). Links.

This is a short description of the U.S. Agency for International Development's (USAID) Climate Change Initiative (1998-2002), which focuses on nine countries (including Russia and Ukraine) and three goals: (1) decreasing greenhouse gas (GHG) sources and improving GHG sinks; (2) increasing the participation of developing countries in the FCCC; and (3) decreasing vulnerability to the threats posed by climate change. A special note indicates that Russia holds $22 \%$ of the world's forested areas, the largest land-based carbon storage (sink) in the world, making it a critical country for carbon management. The forests are threatened by logging and fires, so USAID initiated a reforestation program in 1997 to increase seedling production.

Key words: Russia; GHG/GCC; U.S. Agency for International Development, U.S. government

\section{Energy Trends in WEC Member Countries 1980-1996}

http://www.worldenergy.org/wec-geis/members only/registered/open.plx?file=edc/ default/country/ned/curr/summarydocs/NedSUMtrends.htm

1999. 3 pages. Narrative, charts, links to tabular data

This report provides a summary of energy trends between 1980 and 1986 in selected countries. Primary energy supply in the World Energy Council (WEC) member countries increased by 1.7 $\%$ on average between 1980 and 1996, but this average hides large differences among countries. Links are provided to 12 tables containing energy trend data by country. Data are included on indigenous energy production, energy supply and demand, and electricity supply.

Key words: Bulgaria, Romania, Russia, Turkey, Ukraine; energy; World Energy Council

\section{Russian Federation-Energy Information}

http://www.worldenergy.org/wec-geis/members only/registered/open.plx?file=edc/default/ country/RUS.stm

1998. 16 pages. Narrative, data, links to statistical tables 
This site includes short discussions on Russia's coal, crude oil and liquid natural gas, oil shale, uranium, nuclear, hydropower, peat, solar energy, geothermal energy, tidal energy, downstream gas, downstream oil, upstream oil and gas, and electricity. The narrative summarizes progress in privatization of many of these energy resources. Links are provided to statistical tables from the 1998 International Energy Data Report on energy supply and demand, electricity supply, and $\mathrm{CO}_{2}$ emissions and energy efficiency indications and explanatory material from the 1998 Energy Efficiency Policies and Indicators Report.

Key words: Russia; energy, oil/natural gas; World Energy Council

\section{World Energy Council-Survey of Energy Resources, 1998}

http://www.worldenergy.org/wec-geis/publications/open.plx?file=default/current ser.htm 1998. 1 page. Table of contents, with links to each section

The 1998 survey provides an updated review of world energy resources. It reports the adequacy of the world's total energy resource base and highlights, to an increasing degree, the environmental advantages and disadvantages of each fuel, with a particular and growing emphasis on $\mathrm{CO}_{2}$ and other greenhouse gas emissions. The dominance of the main commercial fossil fuels — oil, gas, and coal—is expected to continue for the foreseeable future, with the share of natural gas increasing. Several renewable energies (e.g., solar, wind) seem to be set on the path of rapid growth and declining cost. This should see them securing competitive advantage, initially in key niche areas, before broadening in role and importance. Site includes data tables with country information.

Key words: Armenia, Azerbaijan, Bulgaria, Georgia, Kazakhstan, Romania, Russia, Turkey, Ukraine; energy, environment, oil/natural gas, GHG/GCC; World Energy Council

\section{Russian Federation at a Glance: Agriculture, Natural Resources, and Environment \\ http://www.wri.org/facts/cs-pdf/russian.pdf}

1996. 4 pages. Data, charts (PDF format)

This World Resources Institute fact sheet highlights data on the Russian Federation's economic and social context; agricultural, forest, freshwater, marine, coastal, and biodiversity resources; energy and mineral resources; and involvement in international agreements. The data for these fact sheets came from the World Resources 1996-97 database, and the project was funded by the Agriculture and Natural Resource Department of the World Bank.

Key words: Russia; economics, environment, energy, international agreements; World Resources Institute 


\section{R. Cullen, "The Caspian Sea" \\ National Geographic}

May 1999. Pages 2-35. Maps, photos, narrative.

“The Soviet Union's breakup left regional economies in tatters; it also spurred the biggest oil rush of the past quarter century." This article documents the social, economic, cultural and environmental issues affecting the countries surrounding the Caspian, and its natural resources. Regional maps and keys depict such factors as income level, gas and oil reserves, landscapes, ethnolinguistic groups, oil/natural gas pipelines, sturgeon catch, etc.

Key words: Azerbaijan, Kazakhstan, Russia, Caspian Sea; energy, environment, economics, oil/natural gas; National Geographic Society.

\section{Black Sea: Voyage of Healing}

Bullfrog Films, Oley, Penn.

1998. 54-min. color video

This video chronicles a symposium on the Black Sea in Crisis, held aboard a cruise ship as it visits the countries of Georgia, Russia, Ukraine, Romania, Bulgaria, and Turkey, in a circumnavigation of the sea. The symposium was convened by the ecumenical patriarch, Bartholomew of Constantinople, of the Eastern Orthodox Church, in hopes of finding solutions to the problems of the Black Sea region. The participants included environmentalists, scientists, writers, and religious thinkers.

Key words: Black Sea, Bulgaria, Georgia, Romania, Russia, Turkey, Ukraine; environment; Bullfrog Films

\section{World Resources, 1998-1999}

World Resources Institute, United Nations Environment Programme, United Nations Development Programme, World Bank, Oxford University Press (USA) 1998. 384 pages. Database is also available on CD-ROM and diskette

This biennial report looks at the current state of the environment as it relates to population and human well-being, consumption and waste, and resources at risk. The book also contains country data from 157 countries and new information on poverty, inequality, and food security.

Key words: Armenia, Azerbaijan, Bulgaria, Georgia, Kazakhstan, Romania, Russia, Turkey, Ukraine; economics, environment, energy, GHG/GCC, oil/natural gas, international agreements; World Resources Institute 


\section{TURKEY}

Event: Bright Role for Innovation in the Black Sea, June 5-7, 2001 http://dbs.cordis.lu/cordis-cgi/srchidadb?ACTION=D\&SESSION=199642000-9$18 \& D O C=29 \&$ TBL=EN NEWS $\&$ RCN=EN RCN ID:15339\&CALLER=EN UNIFIEDS $\underline{\mathrm{RCH}}$ (or search from CORDIS home page for Black Sea events) August 2000. 1 page

The role of research and innovation in the reconstruction and development of the Black Sea Economic Community (BSEC) countries will be discussed at a forthcoming conference in Kharkov, the Ukraine, on June 5-7, 2001. Contact: email: ump@vlink.kharkov.ua . This is an example of information available from the http://www.cordis.lu/en/home.html search system.

Key words: Black Sea, Bulgaria, Georgia, Romania, Russia, Turkey, Ukraine; economics; European Union International Scientific Cooperation

\section{Bosphorus Straits Regulation and Central Asian Oil http://gurukul.ucc.american.edu/ted/BOSPORUS.HTM 1995. 8 pages. Narrative with references}

This site discusses issues surrounding the dispute over Turkish regulations for sea traffic through the straits separating the Mediterranean and Black Seas, including strategic political, environmental, and economic factors. Turkey justified the measures on environmental and safety grounds (from 1988-92 there were 155 collisions in the Straits, and about $60 \%$ of all vessels transport hazardous materials such as oil, gas, and chemicals). Russian exports of natural gas and oil were most affected and led to protests that the new regulations illegally restricted the free passage through the Straits that was guaranteed in the Montreaux Treaty of 1936.

Key words: Russia, Turkey, Black Sea; environment, energy, international agreements; American University

\section{Summit Declaration on Black Sea Economic Cooperation}

http://inter.mfa.gov.tr/grupa/af/Bsec7.HTM

June 1992. 2 pages. Narrative

This site contains the text of the summit declaration at Istanbul, June 25, 1992, agreed to by the heads of state or governments of Albania, Armenia, Azerbaijan, Bulgaria, Georgia, Greece, 
Moldova, Romania, Russia, Turkey, and Ukraine. In the text, the parties state their intention to act to improve the environment and promote economic cooperation in the region.

Key words: Armenia, Azerbaijan, Bulgaria, Georgia, Romania, Russia, Turkey, Ukraine, Black Sea; economics, international agreements; Ministry of Foreign Affairs (Republic of Turkey)

\section{Caspian Oil and Political Implications}

http://www.american.edu/projects/mandala/TED/caspoil.htm

1998. 9 pages. Narrative

Although once thought minimal, Caspian oil reserves are now considered more plentiful than Persian Gulf oil. This paper discusses the various claims on Caspian oil, and the political complications of various pipeline routes from the area. Tensions between Armenia and Azerbaijan threaten the shortest route between Baku and Turkey. Once the oil reaches the Black Sea, the most viable option is to ship it through the Bosporus. This route, however, has environmental implications because there are frequent oil leaks from tankers working their way through the narrow straits

Key words: Armenia, Azerbaijan, Russia, Georgia, Turkey, Black Sea, Caspian Sea; oil/natural gas, environment; American University

\section{Black Sea Web Homepage}

http://www.blackseaweb.net/welcome.html

1999. 1 page (home page). Links

The Black Sea Web is an attempt to provide a management tool and information to assist in integrated marine environmental management of the Black Sea area. The site provides links to map sets (digital atlas, satellite images, thematic maps), data on each of the countries bordering the Black Sea (http://www.blackseaweb.net/general/country.htm), lists of existing environmental programs (http://www.blackseaweb.net/general/epp.htm), list of publications from the Black Sea Environmental Programme (http://www.blackseaweb.net/publications/welcome.html), and a set of environmental links for Bulgaria, Georgia, Romania, Russia, and Ukraine (http://www.blackseaweb.net/general/links.htm). The site also contains a Demonstrator (http://www.blackseaweb.net/demonstrator/welcome.html), which allows a number of physically and geographically separate databases to be accessed remotely through a "Black Sea Web Interface."

Key words: Bulgaria, Georgia, Romania, Russia, Turkey, Ukraine, Black Sea; environment; Black Sea Web Project 


\section{Black Sea Region OPET (Organizations for the Promotion of Energy Technologies) Associate Project}

http://www.bsrec.bg/opet/menus/background1.html

July 2000. 10 pages. Links to project activity descriptions

In May 2000, the Black Sea Regional Energy Center was awarded a project by the European Union to promote innovative renewable and conservation energy technologies, targeted to the market actors from the Black Sea: Albania, Moldova, Russia, Macedonia, Turkey, and Ukraine. The OPET Network "aims to promote the results of new energy technologies and their introduction in society in order to improve energy efficiency and broaden the use of renewable energy sources." Reports on previous OPET projects in the area can also be accessed.

Key words: Russia, Turkey, Ukraine, Black Sea; energy, environment; Black Sea Regional Energy Centre

\section{Black Sea Energy Review, Turkey}

http://www.bsrec.bg/turkey/turkey.html

November 1997. 2 pages (table of contents). Map, interview, links to report,

As a road between Asia and Europe, Turkey plays an important role in the transportation of energy from producing to consuming countries. Turkey has experienced extremely sharp economic growth in recent years. Economic growth was due to a rapidly increasing population, increasing international cooperation, and a booming private sector. This energy review includes a map and interview. The report includes energy balance data, macroeconomic profile data, energy sector organization, energy pricing, energy legislation, economic legislation, financial sector, market reforms, investment opportunities. and an energy directory. (At this time, only the summary appears to be online.)

Key words: Turkey; energy, environment, natural gas/oil, GHG/GCC, economics; European Commission, Black Sea Regional Energy Centre.

\section{The World Factbook-Turkey}

http://www.cia.gov/cia/publications/factbook/geos/tu.html

January 2000. 9 pages. Map, data

An assortment of data about Turkey under the general topics of geography, people, government, economy, communications, transportation, military, and transnational issues. Site includes some information on the economy and electricity production and use, the environment, and environmental agreements. 
Key words: Turkey; economics, environment, energy, international agreements; Central Intelligence Agency, U.S. government

\section{OPET (Organizations for the Promotion of Energy Technologies) Home Page} http://www.cordis.lu/opet/home.html

December 1999. 2 pages. Links to over 80 energy-related web sites worldwide

The OPET Network "aims to promote the results of new energy technologies and their introduction in society in order to improve energy efficiency and broaden the use of renewable energy sources." Links to related sites include European Commission projects, Energy/Environment Research Centers, Energy Trade Associations, publications, events, success stories, and directories. One FEMOPET project focused on the Black Sea Region from 1998 to 2000 (Bulgaria/Romania). This was followed by the Black Sea Region OPET Associate Project (2000-2002, Russia, Turkey, Ukraine). Both projects, in conjunction with the Black Sea Regional Energy Centre, aimed to promote innovative renewable and conservation energy technologies.

Key words: Armenia, Azerbaijan, Black Sea, Bulgaria, Caspian Sea, Romania, Russia, Turkey, Ukraine; energy, environment, oil/natural gas, GHG/GCC, economics, international agreements, institutional development; European Commission Thermie Program

\section{Black Sea Environmental Programme \\ http://www.dominet.com.tr/blacksea/ \\ 1996. 3 pages (home page). Links}

This home page contains a series of links grouped under general topics. Some of the linked material describes the background and structure of the Black Sea Environmental Programme and the Black Sea Environmental Programme Institutional Network. Other links describe the program in 1996 and its activities that year in emergency response, pollution monitoring, biodiversity, integrated coastal zone management, fisheries, database management and geographic information system, environmental economics and investments, nongovernmental organizations, information and communication, and policy and legislation.

Key words: Black Sea, Bulgaria, Georgia, Romania, Russia, Turkey, Ukraine; environment, institutional development, international agreements; Black Sea Environmental Programme, United Nations

\section{Strategic Action Plan for the Rehabilitation and Protection of the Black Sea http://www.eelink.net/ asilwildlife/blacksea.html}


October 1996. 23 pages. Narrative

Site contains text of an agreement among Bulgaria, Georgia, Romania, the Russian Federation, Turkey, and Ukraine, October 30-31, 1996. EE-Link (http://www.eelink.net/) also provides access to other international agreements relating to this region.

Key words: Bulgaria, Georgia, Romania, Russia, Turkey, Ukraine, Black Sea; environment, institutional development, international agreements; EE (Environmental Education) Link

\section{Country Brief: Caspian-Bosporus/Black Sea Issues}

http://www.eia.doe.gov/emeu/cabs/caspblk.html

June 2000. 3 pages. Narrative

Site summarizes issues and concerns about proposed increases in shipment of oil from the Caspian Sea area through the Black Sea and the Bosporus. Impacts on Turkey, Bulgaria, Croatia, Moldova, Romania, and Ukraine are identified.

Key words: Bulgaria, Romania, Turkey, Ukraine, Black Sea, Caspian Sea; environment, oil/natural gas; Energy Information Administration, U.S. government

\section{Country Brief: Caspian Sea Region}

http://www.eia.doe.gov/emeu/cabs/caspian.html

June 2000. 5 pages. Narrative, map, links to related sites

http://www.eia.doe.gov/emeu/cabs/caspfull.html approx 30-page, more detailed report, with tables

The site discusses the oil and gas reserves in the Caspian Sea regions, and issues and options for export routes, including those that impact Bulgaria, Georgia, Romania, Russia, Turkey, Ukraine, and the Black Sea. There is also a discussion of environmental issues affecting the Caspian Sea: oil pollution, waste discharges, sea rise, environmental legislation, and outlook for 21 st century.

Key words: Azerbaijan, Bulgaria, Kazakhstan, Romania, Russia, Turkey, Ukraine, Black Sea, Caspian Sea; oil/natural gas, energy, environment, institutional development, international agreements; Energy Information Administration, U.S. government

\section{Turkey: Environmental Issues}

http://www.eia.doe.gov/emeu/cabs/turkenv.htm

March 2000. 6 pages Narrative, charts 
Site focuses on environmental issues in Turkey resulting from growth and energy use and steps being taken to reduce harmful environmental impacts. Site includes short discussions of marine and air pollution, energy consumption, carbon emissions, energy and carbon intensity, renewable energy, and outlook for the 21 st century.

Key words: Turkey; environment, greenhouse gases, energy; Energy Information Administration, U.S. government

\section{Country Brief: Turkey}

http://www.eia.doe.gov/emeu/cabs/turkey.html

August 2000. 9 pages Narrative, map

Site contains a description of recent economic developments; oil production, consumption, refining, and transportation; natural gas production, consumption, and pipelines; generation of electricity; and environmental impact. The site also contains overview data on the country, economics, energy, environment, and oil and gas, as well as links to other sources of information on Turkey.

Key words: Turkey; economics, oil/natural gas, energy, environment, international agreements; Energy Information Administration, U.S. government

\section{International Data: Turkey}

http://www.eia.doe.gov/emeu/international/turkey.html

January 2000. 1 page. Links

Site contains links to spreadsheet energy and energy-related data for 1980-98, reported by fuel category, a country energy balance, and information on petroleum imports. Links are provided to other reports.

Key words: Turkey; energy, oil/natural gas, GHG/GCC; Energy Information Administration, U.S. government

\section{An Energy Overview of the Republic of Turkey}

http://www.fe.doe.gov/international/turkover.html

September 2000. 14 pages Narrative, data

This site summarizes the Republic of Turkey's energy situation. Turkey expects a large growth in energy demand, especially in electricity and natural gas. The overview considers production and consumption of oil, natural gas, and coal. It considers hydroelectric resources and energy 
infrastructure. Current electricity generation and planned generation capacity are summarized. The site briefly discusses environmental concerns; carbon dioxide, nitrogen oxide, and sulfur dioxide emissions; and economic conditions.

Key words: Turkey; energy, oil/natural gas, economic, environment, GHG/GCC; U.S.

Department of Energy, U.S. government

\section{Black Sea Internet Node}

http://www.grid.unep.ch/bsein/

June 1999. 1 page (home page). Links

This site contains links to information on organizations and scientists studying the Black Sea; (inter)national research projects/programs (since 1990); cruise summary reports (since 1979); Black Sea bibliography (since 1974); acronyms and abbreviations; meta level information on environmental data for the Black Sea region; selected satellite images; and Black Sea Red Data Book (flora and fauna of region). It also contains recent data sets obtained in frameworks of different international programs and copies of some historical data sets opened for public use.

Key words: Bulgaria, Georgia, Romania, Russia, Turkey, Ukraine, Black Sea; environment, international agreements; Black Sea Environment Programme

\section{Black Sea Transboundary Diagnostic Analysis}

http://www.grid.unep.ch/bsein/tda/index.htm

June 1996. 1 page (entry page). Narrative, tables, charts

The web version of the lengthy document is broken into sections accessed from the "Content" page. (Choose "Continue" on entry page.) This report represents the results of a systematic scientific analysis of the root causes of environmental degradation in the Black Sea. The document was prepared by an international team of specialists, most from institutions in the six coastal countries. The report contains information on the environmental problems and causes, major sources and reduction of pollution, fisheries, protection of endangered species and habitats, conservation area management, and sustainable development.

Key words: Bulgaria, Georgia, Romania, Russia, Turkey, Ukraine, Black Sea; environment, international agreements; Global Environmental, Facility Black Sea Environment Programme 


\section{Key Energy Indicators for Turkey}

http://www.iea.org/stats/files/selstats/keyindic/nmc/turkey.htm

1997. 2 pages. Data, chart, map, links

Key energy indicators are presented in a table. Data include population, GDP, energy supply, and electricity consumption. Energy supply and electricity consumption are also shown per capita and per GDP. The chart shows the portion of total energy production by fuel. Links to more detailed information are provided.

Key words: Turkey; energy, economics; International Energy Agency

\section{Facts and Figures: Environmental Data Tables}

http://www.igc.org/wri/facts/data-tables.html

March 2000. 1 page. Links

This page presents links to data tables taken from World Resources 1998-1999. These tables (in PDF format) contain information on atmosphere and climate, biodiversity, economic indicators, energy and materials, food and agriculture, forests and land cover, freshwater, health, oceans and fisheries, population and human development, and urban data.

Key words: Armenia, Azerbaijan, Bulgaria, Georgia, Kazakhstan, Romania, Russia, Turkey, Ukraine; economics, environment, energy, GHG/GCC, gas/oil, international agreements; World Resources Institute

\section{Global Currents and Turkey}

http://www.mfa.gov.tr/grupa/percept/II3/III3-5.html

September-November 1997. 6 pages Narrative

Article by Taner Baytok in Perceptions: Journal of International Affairs II(3), Center for Strategic Research, Ankara, Turkey, September-November 1997. The article discusses in a general sense the impacts of economic change. Baytok focuses on Turkey's potentially increased role in refining oil and in the transportation of oil and gas, as well as the need to preserve the environment and natural beauty of the area.

Key words: Turkey; oil/natural gas, energy; Perceptions: Journal of International Affairs 


\section{The Black Sea Economic Co-Operation and the EU}

http://www.mfa.gov.tr/grupa/percept/i3/I3-6.htm

September-November 1996. 7 pages. Narrative

Article by Ercan Özer in Perceptions: Journal of International Affairs 1(3), Center for Strategic Research, Ankara, Turkey, September-November 1997. The article argues that the European Union and the Black Sea Economic Cooperation can be mutually beneficial organizations and that there are many perspective avenues for cooperation, including the energy resources of the Black Sea area, economic reform, and ending the pollution of the Black Sea.

Key words: Bulgaria, Georgia, Romania, Russia, Turkey, Ukraine, Black Sea; economics, environment, international agreements; Center for Strategic Research

\section{Turkey: Black Sea Pollution Depletes Fishing Stocks}

http://www.rferl.org/nca/features/1998/11/F.RU.981103134427.html

November 1998. 2 pages Narrative

Text of radio report by Jolyon Naegele discussing the pollution of the Black Sea. While much of the pollution comes from other countries, Turkey has been impacted by the severe depletion of the fishing stock. Some species have died off, and the stocks of other species have been greatly reduced.

Key words: Russia, Turkey, Black Sea; environment; Radio Free Europe-Radio Liberty

\section{Sustainable Development: Information on Turkey}

http://www.un.org/esa/agenda21/natlinfo/countr/turkey/index.htm

2000. 1 page. Links

This page provides links to information on four aspects of sustainable development in Turkey: social, natural resource, economic, and institutional. A series of indicators (statistical data) are provided for each aspect. More detail is provided for identified subtopics under each indicator.

Key words: Turkey; energy, environment, GHG/GCC, institutional development, international agreements; United Nations 


\section{United Nations Development Programme (UNDP) Global Environment Facility (GEF)}

http://www.undp.org/gef/portf/climeur.htm

September 2000, updated regularly. 7 pages. Table

UNDP-GEF maintains a current online portfolio of projects by country. Separate tables exist for different GEF focal areas: climate, biodiversity, international waters, and ozone depletion. Included in the portfolio tables are the country name, region, project name, project description, GEF allocation (in millions), and project type (the types are labeled as PDF- Project Development Facility; EA—Enabling Activities; PRIF—Pre-Investment Feasibility Study; FP-Full Project; MSP-Medium-size projects). The portfolio includes regional projects for both Black and Caspian Sea, as well as national projects in nearly every country of the region.

Key words: Armenia, Azerbaijan, Bulgaria, Georgia, Kazakhstan, Romania, Russia, Turkey, Ukraine, Black Sea, Caspian Sea; environment, GHG/GCC, institutional development; United Nations Development Programme

\section{United Nations Development Programme (UNDP) National Human Development Reports http://www.undp.org/hdro/table.htm}

August 2000, updated frequently. 5 pages. Table of available reports, links

More than 100 countries have published National Human Development Reports with UNDP support. By providing comprehensive indicators, the reports help to monitor progress and setbacks in human development and poverty at the national-level. The annual summary report for 2000 is also available online at http://www.undp.org/hdr2000/english/HDR2000.html. The 2000 Human Development Report includes a summary of national indicators such as energy use, growing urbanization, profile of environmental degradation, and access to information and communications. Each report also focuses on a highly topical theme in the current development debate, providing path-breaking analysis and policy recommendations. Individual country reports for some years are available online.

Key words: Armenia, Azerbaijan, Bulgaria, Georgia, Kazakhstan, Romania, Russia, Turkey, Ukraine; energy, environment, GHG/GCC, economics; United Nations Development Programme 


\section{The Ozone Secretariat, UNEP-Nairobi, Kenya}

http://www.unep.ch/ozone/

August 2000. 1 page (home page). Links

Site contains a description of the activities of the Ozone Secretariat, with links to treaties, reports, addresses, and other sites. One of the linked sites (http://www.unep.ch/ozone/ratif.htm) shows each country's signature and ratification status on agreements on the protection of the stratospheric ozone layer.

Key words: Armenia, Azerbaijan, Bulgaria, Georgia, Kazakhstan, Romania, Russia, Turkey, Ukraine; environment, GHG/GCC, international agreements; United Nations Environment Programme

\section{Turkey}

http://www.unfccc.de/resource/country/turkey.html

September 2000. 1 page. Data, links

This United Nations web page shows Turkey's status on signature and ratification of the United Nations Framework Convention and the Kyoto Protocol. Turkey has not signed either agreement. A link is provided to a list of contact points.

Key words: Turkey; environment, GHG/GCC; United Nations Framework Convention on Climate Change

\section{Energy Trends in WEC Member Countries 1980-1996}

http://www.worldenergy.org/wec-geis/members only/registered/open.plx?file=edc/ default/country/ned/curr/summarydocs/NedSUMtrends.htm

1999. 3 pages. Narrative, charts, links to tabular data

This report provides a summary of energy trends between 1980 and 1986 in selected countries. Primary energy supply in the World Energy Council (WEC) member countries increased by 1.7 $\%$ on average between 1980 and 1996, but this average hides large differences among countries. Links are provided to 12 tables containing energy trend data by country. Data are included on indigenous energy production, energy supply and demand, and electricity supply.

Key words: Bulgaria, Romania, Russia, Turkey, Ukraine; energy; World Energy Council 


\section{Turkey-Energy Information}

http://www.worldenergy.org/wec-geis/members only/registered/open.plx?file=edc/default/ country/TUR.stm

1998. 5 pages Narrative, data, links to statistical tables

This site includes short discussions on the energy economy, crude oil and liquid natural gas, nuclear, hydropower, biomass (other than wood), geothermal energy, coal, and electricity. Turkey currently imports more than half its energy, but electrical production has been growing rapidly. Links are provided to statistical tables from the 1998 International Energy Data Report on energy supply and demand, electrical supply, and $\mathrm{CO}_{2}$ emissions.

Key words: Turkey; energy, oil/natural gas; World Energy Council

\section{World Energy Council-Survey of Energy Resources, 1998}

http://www.worldenergy.org/wec-geis/publications/open.plx?file=default/current ser.htm 1998. 1 page. Table of contents, with links to each section

The 1998 survey provides an updated review of world energy resources. It reports the adequacy of the world's total energy resource base and highlights, to an increasing degree, the environmental advantages and disadvantages of each fuel, with a particular and growing emphasis on $\mathrm{CO}_{2}$ and other greenhouse gas emissions. The dominance of the main commercial fossil fuels —oil, gas, and coal—is expected to continue for the foreseeable future, with the share of natural gas increasing. Several renewable energies (e.g., solar, wind) seem to be set on the path of rapid growth and declining cost. This should see them securing competitive advantage, initially in key niche areas, before broadening in role and importance. Site includes data tables with country information.

Key words: Armenia, Azerbaijan, Bulgaria, Georgia, Kazakhstan, Romania, Russia, Turkey, Ukraine; energy, environment, gas/oil, GHG/GCC; World Energy Council

\section{Turkey at a Glance: Agriculture, Natural Resources, and Environment} http://www.wri.org/facts/cs-pdf/turkey.pdf 1997. 4 pages. Data, charts (PDF format)

This World Resources Institute fact sheet highlights data on Turkey's economic and social context; agricultural, forest, freshwater, marine, coastal, and biodiversity resources; energy and mineral resources; and involvement in international agreements. The data for these fact sheets came from the World Resources 1996-97 database, and the project was funded by the Agriculture and Natural Resource Department of the World Bank. 
Key words: Turkey; economics, environment, energy, international agreements; World Resources Institute

\section{Black Sea Energy Survey}

International Energy Agency

June 2000. 256 pages

This study of the Black Sea region as a whole looks at its energy needs and how future oil and gas transport in the region could develop. It reviews the energy policies and sectors of seven countries with diverse energy situations. Azerbaijan is a major oil producer and exporter; Armenia and Georgia are energy-poor; Bulgaria and Romania are EU accession candidates which must restructure their domestic oil and coal industries; Greece and Turkey are IEA member states. This study covers energy strategies, institutions, and restructuring, as well as recent and projected energy trends in these countries. The book analyzes the reforms that are still needed to attract significant investment, both in domestic energy projects and in regional energy trade. A table of contents, sample material, and ordering information are found at http://www.iea.org/pubs/studies/files/blacksea/index.htm .

Key words: Black Sea, Armenia, Azerbaijan, Bulgaria, Georgia, Romania, Turkey; energy, oil/natural gas, economics; International Energy Agency

\section{Black Sea: Voyage of Healing}

Bullfrog Films, Oley, Penn.

1998. 54-min. color video

This video chronicles a symposium on the Black Sea in Crisis, held aboard a cruise ship as it visits the countries of Georgia, Russia, Ukraine, Romania, Bulgaria, and Turkey, in a circumnavigation of the sea. The symposium was convened by the ecumenical patriarch, Bartholomew of Constantinople, of the Eastern Orthodox Church, in hopes of finding solutions to the problems of the Black Sea region. The participants included environmentalists, scientists, writers, and religious thinkers.

Key words: Black Sea, Bulgaria, Georgia, Romania, Russia, Turkey, Ukraine; environment; Bullfrog Films 


\section{World Resources, 1998-1999}

World Resources Institute, United Nations Environment Programme, United Nations

Development Programme, World Bank, Oxford University Press (USA)

1998. 384 pages. Database is also available on CD-ROM and diskette

This biennial report looks at the current state of the environment as it relates to population and human well-being, consumption and waste, and resources at risk. The book also contains country data from 157 countries and new information on poverty, inequality, and food security.

Key words: Armenia, Azerbaijan, Bulgaria, Georgia, Kazakhstan, Romania, Russia, Turkey, Ukraine; economics, environment, energy, GHG/GCC, gas/oil, international agreements; World Resources Institute

\section{UKRAINE}

Event: Bright Role for Innovation in the Black Sea, June 5-7, 2001 http://dbs.cordis.lu/cordis-cgi/srchidadb?ACTION=D\&SESSION=199642000-9$18 \& D O C=29 \&$ TBL $=$ EN NEWS $\&$ RCN=EN RCN ID:15339\&CALLER=EN UNIFIEDS $\underline{\mathrm{RCH}}$ (or search from CORDIS home page for Black Sea events)

August 2000. 1 page

The role of research and innovation in the reconstruction and development of the Black Sea Economic Community (BSEC) countries will be discussed at a forthcoming conference in Kharkov, the Ukraine, on June 5-7, 2001. Contact: email: ump@ vlink.kharkov.ua . This is an example of information available from the http://www.cordis.lu/en/home.html search system.

Key words: Black Sea, Bulgaria, Georgia, Romania, Russia, Turkey, Ukraine; economics; European Union International Scientific Cooperation

\section{Summit Declaration on Black Sea Economic Cooperation http://inter.mfa.gov.tr/grupa/af/Bsec7.HTM \\ June 1992. 2 pages. Narrative}

This site contains the text of the summit declaration at Istanbul, June 25, 1992, agreed to by the heads of state or governments of Albania, Armenia, Azerbaijan, Bulgaria, Georgia, Greece, Moldova, Romania, Russia, Turkey, and Ukraine. In the text, the parties state their intention to act to improve the environment and promote economic cooperation in the region.

Key words: Armenia, Azerbaijan, Bulgaria, Georgia, Romania, Russia, Turkey, Ukraine, Black Sea; economics, international agreements; Ministry of Foreign Affairs (Republic of Turkey) 


\section{Black Sea Environmental Information Center}

http://pims.ed.ornl.gov/blacksea/

2000. 1 page (home page). Links

This site provides information and training on environmental issues and problems related to the Black Sea. The web site provides information on oil spill clean-up and related commercial technologies; various countries' laws, regulations, and standards relating to the environmental condition of the Black Sea; and individuals and companies working on Black Sea environmental issues. The web site provides a real-time chat capability which enables meetings to be conducted online. There is also is an area for scientists to post scientific papers and requests for research partners. The web site is also host to a growing database of historical pollution testing data from research institutes around the Black Sea.

Key words: Bulgaria, Georgia, Romania, Russia, Turkey, Ukraine, Black Sea; environment, international agreements; U.S. Department of Energy

\section{Black Sea Web Homepage}

http://www.blackseaweb.net/welcome.html

1999. 1 page (home page). Links

The Black Sea Web is an attempt to provide a management tool and information to assist in integrated marine environmental management of the Black Sea area. The site provides links to map sets (digital atlas, satellite images, thematic maps), data on each of the countries bordering the Black Sea (http://www.blackseaweb.net/general/country.htm), lists of existing environmental programs (http://www.blackseaweb.net/general/epp.htm), list of publications from the Black Sea Environmental Programme (http://www.blackseaweb.net/publications/welcome.html), and a set of environmental links for Bulgaria, Georgia, Romania, Russia, and Ukraine (http://www.blackseaweb.net/general/links.htm). The site also contains a Demonstrator (http://www.blackseaweb.net/demonstrator/welcome.html), which allows a number of physically and geographically separate databases to be accessed remotely through a "Black Sea Web Interface."

Key words: Bulgaria, Georgia, Romania, Russia, Turkey, Ukraine, Black Sea; environment; Black Sea Web Project

\section{Black Sea Region OPET (Organizations for the Promotion of Energy Technologies) Associate Project}

http://www.bsrec.bg/opet/menus/background1.html

July 2000. 10 pages. Links to project activity descriptions 
In May 2000, the Black Sea Regional Energy Center was awarded a project by the European Union to promote innovative renewable and conservation energy technologies, targeted to the market actors from the Black Sea: Albania, Moldova, Russia, Macedonia, Turkey, and Ukraine. The OPET Network "aims to promote the results of new energy technologies and their introduction in society in order to improve energy efficiency and broaden the use of renewable energy sources." Reports on previous OPET projects in the area can also be accessed.

Key words: Russia, Turkey, Ukraine, Black Sea; energy, environment; Black Sea Regional Energy Centre

\section{OPET (Organizations for the Promotion of Energy Technologies) Home Page} http://www.cordis.lu/opet/home.html

December 1999. 2 pages. Links to over 80 energy-related web sites worldwide

The OPET Network "aims to promote the results of new energy technologies and their introduction in society in order to improve energy efficiency and broaden the use of renewable energy sources." Links to related sites include European Commission projects, Energy/Environment Research Centers, Energy Trade Associations, publications, events, success stories, and directories. One FEMOPET project focused on the Black Sea Region from 1998 to 2000 (Bulgaria/Romania). This was followed by the Black Sea Region OPET Associate Project (2000-2002, Russia, Turkey, Ukraine). Both projects, in conjunction with the Black Sea Regional Energy Centre, aimed to promote innovative renewable and conservation energy technologies.

Key words: Armenia, Azerbaijan, Black Sea, Bulgaria, Caspian Sea, Romania, Russia, Turkey, Ukraine; energy, environment, oil/natural gas, GHG/GCC, economics, international agreements, institutional development; European Commission Thermie Program

\section{Black Sea Environmental Programme}

http://www.dominet.com.tr/blacksea/

1996. 3 pages (home page). Links

This home page contains a series of links grouped under general topics. Some of the linked material describes the background and structure of the Black Sea Environmental Programme and the Black Sea Environmental Programme Institutional Network. Other links describe the program in 1996 and its activities that year in emergency response, pollution monitoring, biodiversity, integrated coastal zone management, fisheries, database management and geographic information system, environmental economics and investments, nongovernmental organizations, information and communication, and policy and legislation. 
Key words: Black Sea, Bulgaria, Georgia, Romania, Russia, Turkey, Ukraine; environment, institutional development, international agreements; Black Sea Environmental Programme, United Nations

\section{Strategic Action Plan for the Rehabilitation and Protection of the Black Sea}

http://www.eelink.net/ asilwildlife/blacksea.html

October 1996. 23 pages. Narrative

Site contains text of an agreement among Bulgaria, Georgia, Romania, the Russian Federation, Turkey, and Ukraine, October 30-31, 1996. EE-Link (http://www.eelink.net/) also provides access to other international agreements relating to this region.

Key words: Bulgaria, Georgia, Romania, Russia, Turkey, Ukraine, Black Sea; environment, institutional development, international agreements; EE (Environmental Education) Link

\section{The World Factbook-Ukraine}

http://www.cia.gov/cia/publications/factbook/geos/up.html

January 2000. 9 pages. Map, data

An assortment of data about Ukraine under the general topics of geography, people, government, economy, communications, transportation, military, and transnational issues. Site includes some information on the economy, electricity production and use, environment, and environmental agreements.

Key words: Ukraine; economics, environment, energy, international agreements; Central Intelligence Agency, U.S. government

\section{Country Brief: Caspian-Bosporus/Black Sea Issues}

http://www.eia.doe.gov/emeu/cabs/caspblk.html

June 2000. 3 pages. Narrative

Site summarizes issues and concerns about proposed increases in shipment of oil from the Caspian Sea area through the Black Sea and the Bosporus. Impacts on Turkey, Bulgaria, Croatia, Moldova, Romania, and Ukraine are identified.

Key words: Bulgaria, Romania, Turkey, Ukraine, Black Sea, Caspian Sea; environment, oil/natural gas; Energy Information Administration, U.S. government

\section{Country Brief: Ukraine}


http://www.eia.doe.gov/cabs/ukraine.html

August 2000. 8 pages. Narrative, map, charts, data

Site contains a description of recent economic developments; oil production, consumption, and transportation; natural gas production, consumption, and pipelines; coal mining and consumption; generation of electricity (including nuclear power); and environmental impact. The site also contains overview data on the country, economics, energy, environment, and oil and gas, as well as links to other sources of information on Ukraine.

Key words: Ukraine; economics, oil/natural gas, energy, environment, international agreements; Energy Information Administration, U.S. government

\section{Country Brief: Caspian Sea Region}

http://www.eia.doe.gov/emeu/cabs/caspian.html

June 2000. 5 pages. Narrative, map, links to related sites

http://www.eia.doe.gov/emeu/cabs/caspfull.html approx 30-page, more detailed report, with tables

The site discusses the oil and gas reserves in the Caspian Sea regions, and issues and options for export routes, including those that impact Bulgaria, Georgia, Romania, Russia, Turkey, Ukraine, and the Black Sea. There is also a discussion of environmental issues affecting the Caspian Sea: oil pollution, waste discharges, sea rise, environmental legislation, and outlook for 21 st century.

Key words: Azerbaijan, Bulgaria, Kazakhstan, Romania, Russia, Turkey, Ukraine, Black Sea, Caspian Sea; oil/natural gas, energy, environment, institutional development, international agreements; Energy Information Administration, U.S. government

\section{Ukraine: Environmental Issues}

http://www.eia.doe.gov/emeu/cabs/ukrenv.htm

January 2000. 5 pages. Narrative, charts

Site focuses on environmental issues in Ukraine, resulting from the Chernobyl accident, industrial pollution, and aging equipment, and steps being taken to reduce harmful environmental impacts. Site includes short discussions of air pollution, energy consumption, carbon emissions, energy and carbon intensity, renewable energy, nuclear power, and outlook for the $21 \mathrm{st}$ century.

Key words: Ukraine; environment, greenhouse gases, energy; Energy Information Administration, U.S. government 


\section{International Data: Ukraine}

http://www.eia.doe.gov/emeu/international/ukraine.html

January 2000. 1 page. Links

Site contains links to spreadsheet energy and energy-related data for 1992-98, reported by fuel category and a country energy balance. Links are provided to other reports.

Key words: Ukraine; energy, oil/natural gas, GHG/GCC; Energy Information Administration, U.S. government

\section{Ukraine}

http://www-esd.worldbank.org/ecssd/envcopg/esukra.html

September 1998. 4 pages. Map, narrative, data

The site contains a country map and data on land and water use, natural resources, biodiversity, energy efficiency, $\mathrm{CO}_{2}$ emissions, and treaty participation. The key environmental problems are briefly described. Current World Bank environment and rural development projects are listed, along with country and World Bank contacts.

Key words: Ukraine; environment, GHG/GCC; World Bank

\section{Mobile Laboratory for the Ukraine, US Environmental Protection Agency (EPA)} http://www.epa.gov/narelweb/ukraine.html No date given. 1 page. Links.

Site describes a project with Ukraine's Ministry of Environmental Protection and Nuclear Safety to increase capacity for environmental monitoring through training and a modern, mobile laboratory equipped for radiological and water quality analyses. Links to the 1995 project document (9 pages) and partner organizations: United Nations Development Program (UNDP), Tuskegee University, and the United Nations office in Ukraine.

Key words: Ukraine; energy, environment; U.S. Environmental Protection Agency, National Air and Radiation Environmental Laboratory

\section{Black Sea Internet Node}

http://www.grid.unep.ch/bsein/

June 1999. 1 page (home page). Links 
This site contains links to information on organizations and scientists studying the Black Sea; (inter)national research projects/programs (since 1990); cruise summary reports (since 1979); Black Sea bibliography (since 1974); acronyms and abbreviations; meta level information on environmental data for the Black Sea region; selected satellite images; and Black Sea Red Data Book (flora and fauna of region). It also contains recent data sets obtained in frameworks of different international programs and copies of some historical data sets opened for public use.

Key words: Bulgaria, Georgia, Romania, Russia, Turkey, Ukraine, Black Sea; environment, international agreements; Black Sea Environment Programme

\section{Black Sea Transboundary Diagnostic Analysis}

http://www.grid.unep.ch/bsein/tda/index.htm

June 1996. 1 page (entry page). Narrative, tables, charts

The web version of the lengthy document is broken into sections accessed from the "Content" page. (Choose "Continue" on entry page.) This report represents the results of a systematic scientific analysis of the root causes of environmental degradation in the Black Sea. The document was prepared by an international team of specialists, most from institutions in the six coastal countries. The report contains information on the environmental problems and causes, major sources and reduction of pollution, fisheries, protection of endangered species and habitats, conservation area management, and sustainable development.

Key words: Bulgaria, Georgia, Romania, Russia, Turkey, Ukraine, Black Sea; environment, international agreements; Global Environmental, Facility Black Sea Environment Programme

\section{National Report on Conservation of Biological Diversity in Ukraine}

http://www.grida.no/enrin/biodiv/biodiv/national/ukraine/l ind/index.htm

February 2000. 1 page (home page). Links

This web page links to sections of the National Report on Conservation of Biological Diversity in Ukraine. The report describes the biological diversity in Ukraine, natural reserves, and plans and organizations responsible for protecting the environment.

Key words: Ukraine; environment, institutional development; Ministry for Environmental Protection and Nuclear Safety of Ukraine

\section{Ukraine ENRIN Home}

http://www.grida.no/enrin/htmls/ukraina/index.htm

October 1998. Home page, map, links. 
The National Report on the State of Environment in Ukraine 1998

(http://www.freenet.kiev.ua:8080/ciesin/er98/englv/index.htm) is provided along with other reports on environmental monitoring, information systems, contacts and country links for Ukraine. The Environment and Natural Resource Information Network (ENRIN) in Central and Eastern Europe and Newly Independent States (CEE/NIS) home page provides direct links to reports on 27 countries in the region, including 25 national State of Environment Reports, 22 national reports on biodiversity, national contacts, regional activities, publications and other links.

Key words: Ukraine; environment, energy, institutional development; United Nations Environment Programme

\section{Key Energy Indicators for Ukraine}

http://www.iea.org/stats/files/selstats/keyindic/nmc/ukraine.htm

1997. 2 pages. Data, chart, map, links

Key energy indicators are presented in a table. Data include population, GDP, energy supply, and electricity consumption. Energy supply and electricity consumption are also shown per capita and per GDP. The chart shows the portion of total energy production by fuel. Links to more detailed information are provided.

Key words: Ukraine; energy, economics; International Energy Agency

\section{Facts and Figures: Environmental Data Tables}

http://www.igc.org/wri/facts/data-tables.html

March 2000. 1 page. Links

This page presents links to data tables taken from World Resources 1998-1999. These tables (in PDF format) contain information on atmosphere and climate, biodiversity, economic indicators, energy and materials, food and agriculture, forests and land cover, freshwater, health, oceans and fisheries, population and human development, and urban data.

Key words: Armenia, Azerbaijan, Bulgaria, Georgia, Kazakhstan, Romania, Russia, Turkey, Ukraine; economics, environment, energy, GHG/GCC, gas/oil, international agreements; World Resources Institute 


\section{The Black Sea Economic Co-Operation and the EU}

http://www.mfa.gov.tr/grupa/percept/i3/I3-6.htm

September-November 1996. 7 pages. Narrative

Article by Ercan Özer in Perceptions: Journal of International Affairs 1(3), Center for Strategic Research, Ankara, Turkey, September-November 1997. The article argues that the European Union and the Black Sea Economic Cooperation can be mutually beneficial organizations and that there are many perspective avenues for cooperation, including the energy resources of the Black Sea area, economic reform, and ending the pollution of the Black Sea.

Key words: Bulgaria, Georgia, Romania, Russia, Turkey, Ukraine, Black Sea; economics, environment, international agreements; Center for Strategic Research

\section{State of Environment Report, Kiev}

http://www.nature.org.ua/kiev98/

Contents page linked to full report dated 1998

The Contents page provides icons indicating the status of environmental features and progress. Clicking on the icons allows the reader to go quickly to a desired chapter of the report. Physical and social environmental conditions are analyzed along with external impacts. Sources of the problems are assessed (energy, industry, recreation, transport) and efforts to improve conditions are reviewed. There are also sections on indictors, resources and actions.

Key words: Ukraine; environment, energy; Ministry of Environmental Protection of Ukraine, United Nations Environment Programme

\section{Fluxes of Greenhouse Gases in the Northwestern Region of the Black Sea Coastal Zone-Influence of the Danube River System}

http://www.nitg.tno.nl/eng/projects/3 danube/index.shtml

No date given. 1 page (first of 3 linked pages)

The site describes an ongoing project (in the second of three years) to measure greenhouse gases in natural sediments within the Danube Delta. The project aims to evaluate the contribution of gas expulsions from different parts of the delta; evaluate and model the effects of river channels and arms on gas production in shallow lakes; calculate total annual fluxes of $\mathrm{CO}_{2}, \mathrm{~N}_{2} \mathrm{O}$, and $\mathrm{CH}_{4}$ from the entire delta region; and to provide model input for predicting the changes in gas emissions due to changes in the delta morphology and ecology.

Key words: Bulgaria, Romania, Ukraine, Black Sea; GHG/GCC; Netherlands Institute of Applied Geoscience TNO-National Geological Survey 


\section{Sustainable Development: Information on Ukraine}

http://www.un.org/esa/agenda21/natlinfo/countr/ukraine/index.htm

2000. 1 page. Links

This page provides links to information on four aspects of sustainable development in Ukraine: social, natural resource, economic, and institutional. A series of indicators (statistical data) are provided for each. More detail is provided for identified subtopics under each indicator.

Key words: Ukraine; energy, environment, GHG/GCC, institutional development, international agreements; United Nations

\section{United Nations Development Programme (UNDP) Global Environment Facility (GEF)}

http://www.undp.org/gef/portf/climeur.htm

September 2000, updated regularly. 7 pages. Table

UNDP-GEF maintains a current online portfolio of projects by country. Separate tables exist for different GEF focal areas: climate, biodiversity, international waters, and ozone depletion. Included in the portfolio tables are the country name, region, project name, project description, GEF allocation (in millions), and project type (the types are labeled as PDF- Project Development Facility; EA—Enabling Activities; PRIF—Pre-Investment Feasibility Study; FP-Full Project; MSP-Medium-size projects). The portfolio includes regional projects for both Black and Caspian Sea, as well as national projects in nearly every country of the region.

Key words: Armenia, Azerbaijan, Bulgaria, Georgia, Kazakhstan, Romania, Russia, Turkey, Ukraine, Black Sea, Caspian Sea; environment, GHG/GCC, institutional development; United Nations Development Programme

\section{United Nations Development Programme (UNDP) National Human Development Reports http://www.undp.org/hdro/table.htm} August 2000, updated frequently. 5 pages. Table of available reports, links

More than 100 countries have published National Human Development Reports with UNDP support. By providing comprehensive indicators, the reports help to monitor progress and setbacks in human development and poverty at the national-level. The annual summary report for 2000 is also available online at http://www.undp.org/hdr2000/english/HDR2000.html. The 2000 Human Development Report includes a summary of national indicators such as energy use, growing urbanization, profile of environmental degradation, and access to information and 
communications. Each report also focuses on a highly topical theme in the current development debate, providing path-breaking analysis and policy recommendations. Individual country reports for some years are available online.

Key words: Armenia, Azerbaijan, Bulgaria, Georgia, Kazakhstan, Romania, Russia, Turkey, Ukraine; energy, environment, GHG/GCC, economics; United Nations Development Programme

\section{The Ozone Secretariat, UNEP-Nairobi, Kenya}

http://www.unep.ch/ozone/

August 2000. 1 page (home page). Links

Site contains a description of the activities of the Ozone Secretariat, with links to treaties, reports, addresses, and other sites. One of the linked sites (http://www.unep.ch/ozone/ratif.htm) shows each country's signature and ratification status on agreements on the protection of the stratospheric ozone layer.

Key words: Armenia, Azerbaijan, Bulgaria, Georgia, Kazakhstan, Romania, Russia, Turkey, Ukraine; environment, GHG/GCC, international agreements; United Nations Environment Programme

\section{Ukraine}

http://www.unfccc.de/resource/country/ukraine.html

September 2000.1 page. Data, links

This United Nations web page shows Ukraine's status on signature and ratification of the United Nations Framework Convention. Ukraine has ratified the Framework Convention and signed the Kyoto Protocol. A link is provided to a list of contact points.

Key words: Ukraine; environment, GHG/GCC; United Nations Framework Convention on Climate Change

\section{U.S. Agency for International Development, USAID Country Profile, Ukraine} http://www.usaid.gov/countries/ua/ukr.htm

April 1996. 2 pages. Narrative, data

Short statistical summary on Ukraine and an overview of the U.S. Agency for International Development's strategic objectives to assist the nation with its transition to democracy and a broad-based market economy, while improving the social support services required by the population. 
Key words: Ukraine; economics; U.S. Agency for International Development, U.S. government

\section{U.S. Agency for International Development, Ukraine Program Overview} http://www.usaid.gov/country/ee/ua/

August 2000, updated regularly. 3 pages. Narrative, links

Based on annual reports and congressional presentations, a frank assessment of development challenges (political and economic issues) is presented with an overview of U.S. assistance priorities, programs, progress, and funding, and a summary of other donor activities. Ukraine received U.S. assistance for restructuring and modernizing in the agriculture, finance, energy, and environment sectors. Progress in energy and environmental programs included (1) new commitments from the National Electricity Regulatory Commission for the transition to a competitive, market-based sector; (2) application of energy efficiency technologies for industry; and (3) the transfer of modeling technology that dramatically increased local capacity to provide reliable water services. Details by sector-including objectives, indicators, budgets, other donor programs and progress to date — can be accessed through the "2001 Program/Activities" link. Site includes links to additional U.S. Agency for International Development program reports, budget tables, press releases, search engine and State Department information.

Key words: Ukraine; energy, environment; U.S. Agency for International Development, U.S. government

\section{U.S. Agency for International Development, Press Release, New Environmental Initiative in Ukraine} http://www.usaid.gov/press/releases/2000/pr000605 4.html

June 2000. 2 pages. Narrative

The U.S. Agency for International Development (USAID) announced a new, \$1.6 million Local Environment Action Program to assist Ukraine municipalities in addressing their most important environmental problems through small grants and technical assistance. Later press releases can be found with the USAID search engine at http://search.info.usaid.gov/.

Key words: Ukraine; environment; U.S. Agency for International Development, U.S. government

\section{Energy Trends in WEC Member Countries 1980-1996}

http://www.worldenergy.org/wec-geis/members only/registered/open.plx?file=edc/ default/country/ned/curr/summarydocs/NedSUMtrends.htm 
1999. 3 pages. Narrative, charts, links to tabular data

This report provides a summary of energy trends between 1980 and 1986 in selected countries. Primary energy supply in the World Energy Council (WEC) member countries increased by 1.7 $\%$ on average between 1980 and 1996, but this average hides large differences among countries. Links are provided to 12 tables containing energy trend data by country. Data are included on indigenous energy production, energy supply and demand, and electricity supply.

Key words: Bulgaria, Romania, Russia, Turkey, Ukraine; energy; World Energy Council

\section{Ukraine-Energy Information}

http://www.worldenergy.org/wec-geis/members only/registered/open.plx?file=edc/default/ country/UKR.stm

1998. 12 pages. Narrative, data, links to statistical tables

This site includes short discussions of the energy economy, crude oil and liquid natural gas, upstream oil and gas, natural gas, downstream gas, uranium, nuclear, hydropower, peat, coal, and electricity. The electricity generation and distribution system in Ukraine is in critical condition, with aging power plants, no emission controls, and increased use of low-quality coal. Links are provided to statistical tables from the 1998 International Energy Data Report on energy supply and demand, electricity supply, and $\mathrm{CO}_{2}$ emissions.

Key words: Ukraine; energy, oil/natural gas; World Energy Council

\section{World Energy Council-Survey of Energy Resources, 1998}

http://www.worldenergy.org/wec-geis/publications/open.plx?file=default/current ser.htm 1998. 1 page. Table of contents, with links to each section

The 1998 survey provides an updated review of world energy resources. It reports the adequacy of the world's total energy resource base and highlights, to an increasing degree, the environmental advantages and disadvantages of each fuel, with a particular and growing emphasis on $\mathrm{CO}_{2}$ and other greenhouse gas emissions. The dominance of the main commercial fossil fuels — oil, gas, and coal—is expected to continue for the foreseeable future, with the share of natural gas increasing. Several renewable energies (e.g., solar, wind) seem to be set on the path of rapid growth and declining cost. This should see them securing competitive advantage, initially in key niche areas, before broadening in role and importance. Site includes data tables with country information.

Key words: Armenia, Azerbaijan, Bulgaria, Georgia, Kazakhstan, Romania, Russia, Turkey, Ukraine; energy, environment, oil/natural gas, GHG/GCC; World Energy Council 


\section{Ukraine at a Glance: Agriculture, Natural Resources, and Environment}

http://www.wri.org/facts/cs-pdf/ukraine.pdf

1997. 4 pages. Data, charts (PDF format)

This World Resources Institute fact sheet highlights data on Ukraine's economic and social context; agricultural, forest, freshwater, marine, coastal, and biodiversity resources; energy and mineral resources; and involvement in international agreements. The data for these fact sheets came from the World Resources 1996-97 database, and the project was funded by the Agriculture and Natural Resource Department of the World Bank.

Key words: Ukraine; economics, environment, energy, international agreements; World Resources Institute

\section{Black Sea: Voyage of Healing}

Bullfrog Films, Oley, Penn.

1998. 54-min. color video

This video chronicles a symposium on the Black Sea in Crisis, held aboard a cruise ship as it visits the countries of Georgia, Russia, Ukraine, Romania, Bulgaria, and Turkey, in a circumnavigation of the sea. The symposium was convened by the ecumenical patriarch, Bartholomew of Constantinople, of the Eastern Orthodox Church, in hopes of finding solutions to the problems of the Black Sea region. The participants included environmentalists, scientists, writers, and religious thinkers.

Key words: Black Sea, Bulgaria, Georgia, Romania, Russia, Turkey, Ukraine; environment; Bullfrog Films

\section{World Resources, 1998-1999}

World Resources Institute, United Nations Environment Programme, United Nations Development Programme, World Bank, Oxford University Press (USA) 1998. 384 pages. Database is also available on CD-ROM and diskette

This biennial report looks at the current state of the environment as it relates to population and human well-being, consumption and waste, and resources at risk. The book also contains country data from 157 countries and new information on poverty, inequality, and food security.

Key words: Armenia, Azerbaijan, Bulgaria, Georgia, Kazakhstan, Romania, Russia, Turkey, Ukraine; economics, environment, energy, GHG/GCC, oil/natural gas, international agreements; World Resources Institute 


\section{BLACK SEA REGION}

\section{Event: Bright Role for Innovation in the Black Sea, June 5-7, 2001}

http://dbs.cordis.lu/cordis-cgi/srchidadb?ACTION=D\&SESSION=199642000-9$18 \& D O C=29 \& T B L=E N$ NEWS $\&$ RCN=EN RCN ID:15339\&CALLER=EN UNIFIEDS $\underline{\mathrm{RCH}}$ (or search from CORDIS home page for Black Sea events) August 2000. 1 page

The role of research and innovation in the reconstruction and development of the Black Sea Economic Community (BSEC) countries will be discussed at a forthcoming conference in Kharkov, the Ukraine, on June 5-7, 2001. Contact: email: ump@vlink.kharkov.ua . This is an example of information available from the http://www.cordis.lu/en/home.html search system.

Key words: Black Sea, Bulgaria, Georgia, Romania, Russia, Turkey, Ukraine; economics; European Union International Scientific Cooperation

\section{SYNERGY}

http://europa.eu.int/en/comm/dg17/syn01en.htm

July 1999. 11 pages. Links (to more recent news and program information)

Synergy is a program of the European Union, which finances international cooperation projects with third countries (Euro\$ 7 million in 1999) to help them define, formulate, and implement their energy policies through advice and training, analysis and forecasting in energy matters, organization of conferences and seminars, support to regional transboundary cooperation, and improving the framework for industrial energy cooperation in fields of mutual interest. Synergy funds the Black Sea Regional Energy Center.

Key words: Black Sea; energy; European Union

\section{Bosphorus Straits Regulation and Central Asian Oil}

http://gurukul.ucc.american.edu/ted/BOSPORUS.HTM

1995. 8 pages. Narrative with references

This site discusses issues surrounding the dispute over Turkish regulations for sea traffic through the straits separating the Mediterranean and Black Seas, including strategic political, environmental, and economic factors. Turkey justified the measures on environmental and safety grounds (from 1988-92 there were 155 collisions in the Straits, and about $60 \%$ of all vessels transport hazardous materials such as oil, gas, and chemicals). Russian exports of natural gas and oil were most affected and led to protests that the new regulations illegally 
restricted the free passage through the Straits that was guaranteed in the Montreaux Treaty of 1936.

Key words: Russia, Turkey, Black Sea; environment, energy, international agreements; American University

\section{Summit Declaration on Black Sea Economic Cooperation} http://inter.mfa.gov.tr/grupa/af/Bsec7.HTM

June 1992. 2 pages. Narrative

This site contains the text of the summit declaration at Istanbul, June 25, 1992, agreed to by the heads of state or governments of Albania, Armenia, Azerbaijan, Bulgaria, Georgia, Greece, Moldova, Romania, Russia, Turkey, and Ukraine. In the text, the parties state their intention to act to improve the environment and promote economic cooperation in the region.

Key words: Armenia, Azerbaijan, Bulgaria, Georgia, Romania, Russia, Turkey, Ukraine, Black Sea; economics, international agreements; Ministry of Foreign Affairs (Republic of Turkey)

\section{Black Sea Environmental Information Center}

http://pims.ed.ornl.gov/blacksea/

2000. 1 page (home page). Links

This site provides information and training on environmental issues and problems related to the Black Sea. The web site provides information on oil spill clean-up and related commercial technologies; various countries' laws, regulations, and standards relating to the environmental condition of the Black Sea; and individuals and companies working on Black Sea environmental issues. The web site provides a real-time chat capability which enables meetings to be conducted online. There is also is an area for scientists to post scientific papers and requests for research partners. The web site is also host to a growing database of historical pollution testing data from research institutes around the Black Sea.

Key words: Bulgaria, Georgia, Romania, Russia, Turkey, Ukraine, Black Sea; environment, international agreements; U.S. Department of Energy

\section{Protocol on Protection of the Black Sea Marine Environment Against Pollution from Land Based Sources}

http://sedac.ciesin.org/pidb/texts/acrc/BlackSeaLBP.txt.html

1998 (web site). April 1992 (Convention and protocol). 7 pages. Narrative. 
This protocol to the Convention on the Protection of the Black Sea against Pollution describes procedures and definitions for preventing, reducing and controlling pollution from land based sources that impact on the Black Sea. The Socioeconomic Data Applications Center (SEDAC) maintains the Center for International Earth Science Information Network (CIESIN) Environmental Treaties and Resource Indicators (ENTRI) online at http://sedac.ciesin.org/entri/. Summaries, information on status, and full text for many international treaties and conventions are available.

Key words: Bulgaria, Georgia, Romania, Russia, Black Sea; environment, international agreements; Center for International Earth Science Information Network

\section{Black Sea Ecosystem Processes and Forecasting/Operational Database Management System}

http://sfp1.ims.metu.edu.tr/

August 2000. 1 page (home page). Links

This site highlights a four-year collaborative project sponsored by the North Atlantic Treaty Organization (NATO) aimed at collecting marine data, developing prediction models and to further develop a NATO data management system. The project, which began in 1998, has participants from marine research institutes around the Black Sea and is led by a designated co-director from each institute. The web site describes the tasks of the project, the institutions involved with the project, and methodology for collecting data. Web site information is also available on a CD-ROM.

Key words: Black Sea; environment; North Atlantic Treaty Organization

\section{Caspian Oil and Political Implications}

http://www.american.edu/projects/mandala/TED/caspoil.htm

1998. 9 pages. Narrative

Although once thought minimal, Caspian oil reserves are now considered more plentiful than Persian Gulf oil. This paper discusses the various claims on Caspian oil, and the political complications of various pipeline routes from the area. Tensions between Armenia and Azerbaijan threaten the shortest route between Baku and Turkey. Once the oil reaches the Black Sea, the most viable option is to ship it through the Bosporus. This route, however, has environmental implications because there are frequent oil leaks from tankers working their way through the narrow straits

Key words: Armenia, Azerbaijan, Russia, Georgia, Turkey, Black Sea, Caspian Sea; oil/natural gas, environment; American University 


\section{Black Sea Web Homepage}

http://www.blackseaweb.net/welcome.html

1999. 1 page (home page). Links

The Black Sea Web is an attempt to provide a management tool and information to assist in integrated marine environmental management of the Black Sea area. The site provides links to map sets (digital atlas, satellite images, thematic maps), data on each of the countries bordering the Black Sea (http://www.blackseaweb.net/general/country.htm), lists of existing environmental programs (http://www.blackseaweb.net/general/epp.htm), list of publications from the Black Sea Environmental Programme (http://www.blackseaweb.net/publications/welcome.html), and a set of environmental links for Bulgaria, Georgia, Romania, Russia, and Ukraine (http://www.blackseaweb.net/general/links.htm). The site also contains a Demonstrator (http://www.blackseaweb.net/demonstrator/welcome.html), which allows a number of physically and geographically separate databases to be accessed remotely through a "Black Sea Web Interface."

Key words: Bulgaria, Georgia, Romania, Russia, Turkey, Ukraine, Black Sea; environment; Black Sea Web Project

\section{Black Sea Region OPET (Organizations for the Promotion of Energy Technologies) Associate Project}

http://www.bsrec.bg/opet/menus/background1.html

July 2000. 10 pages. Links to project activity descriptions

In May 2000, the Black Sea Regional Energy Center was awarded a project by the European Union to promote innovative renewable and conservation energy technologies, targeted to the market actors from the Black Sea: Albania, Moldova, Russia, Macedonia, Turkey, and Ukraine. The OPET Network "aims to promote the results of new energy technologies and their introduction in society in order to improve energy efficiency and broaden the use of renewable energy sources." Reports on previous OPET projects in the area can also be accessed.

Key words: Russia, Turkey, Ukraine, Black Sea; energy, environment; Black Sea Regional Energy Centre 


\section{Black Sea Energy Reviews, EC Synergy Program}

http://www.bsrec.bg/tablereviews.html

September 1999. 1 page (home page). Links

The European Commission established the "Black Sea Regional Energy Centre" with Central Asian nations to increase cooperation between the European Union and the Black Sea countries in the energy sector. The site provides a link to detailed online reports for each nation, including tables and discussion of basic energy consumption, production, electricity, forecasts for demand and sources of production, imports, pricing, pollution, emissions and regulations.

Key words: Black Sea; energy, environment, natural gas/oil, GHG/GCC, economics, international agreements, institutional development; European Commission, Black Sea Regional Energy Centre.

\section{OPET (Organizations for the Promotion of Energy Technologies) Home Page} http://www.cordis.lu/opet/home.html

December 1999. 2 pages. Links to over 80 energy-related web sites worldwide

The OPET Network "aims to promote the results of new energy technologies and their introduction in society in order to improve energy efficiency and broaden the use of renewable energy sources." Links to related sites include European Commission projects, Energy/Environment Research Centers, Energy Trade Associations, publications, events, success stories, and directories. One FEMOPET project focused on the Black Sea Region from 1998 to 2000 (Bulgaria/Romania). This was followed by the Black Sea Region OPET Associate Project (2000-2002, Russia, Turkey, Ukraine). Both projects, in conjunction with the Black Sea Regional Energy Centre, aimed to promote innovative renewable and conservation energy technologies.

Key words: Armenia, Azerbaijan, Black Sea, Bulgaria, Caspian Sea, Romania, Russia, Turkey, Ukraine; energy, environment, oil/natural gas, GHG/GCC, economics, international agreements, institutional development; European Commission Thermie Program

\section{Black Sea Environmental Programme}

http://www.dominet.com.tr/blacksea/

1996. 3 pages (home page). Links

This home page contains a series of links grouped under general topics. Some of the linked material describes the background and structure of the Black Sea Environmental Programme and the Black Sea Environmental Programme Institutional Network. Other links describe the program in 1996 and its activities that year in emergency response, pollution monitoring, 
biodiversity, integrated coastal zone management, fisheries, database management and geographic information system, environmental economics and investments, nongovernmental organizations, information and communication, and policy and legislation.

Key words: Black Sea, Bulgaria, Georgia, Romania, Russia, Turkey, Ukraine; environment, institutional development, international agreements; Black Sea Environmental Programme, United Nations

\section{Strategic Action Plan for the Rehabilitation and Protection of the Black Sea http://www.eelink.net/ asilwildlife/blacksea.html}

October 1996. 23 pages. Narrative

Site contains text of an agreement among Bulgaria, Georgia, Romania, the Russian Federation, Turkey, and Ukraine, October 30-31, 1996. EE-Link (http://www.eelink.net/) also provides access to other international agreements relating to this region.

Key words: Bulgaria, Georgia, Romania, Russia, Turkey, Ukraine, Black Sea; environment, institutional development, international agreements; EE (Environmental Education) Link

\section{Country Brief: Caspian-Bosporus/Black Sea Issues}

http://www.eia.doe.gov/emeu/cabs/caspblk.html

June 2000. 3 pages. Narrative

Site summarizes issues and concerns about proposed increases in shipment of oil from the Caspian Sea area through the Black Sea and the Bosporus. Impacts on Turkey, Bulgaria, Croatia, Moldova, Romania, and Ukraine are identified.

Key words: Bulgaria, Romania, Turkey, Ukraine, Black Sea, Caspian Sea; environment, oil/natural gas; Energy Information Administration, U.S. government

\section{Country Brief: Caspian Sea Region}

http://www.eia.doe.gov/emeu/cabs/caspian.html

June 2000. 5 pages. Narrative, map, links to related sites

http://www.eia.doe.gov/emeu/cabs/caspfull.html approx 30-page, more detailed report, with tables

The site discusses the oil and gas reserves in the Caspian Sea regions, and issues and options for export routes, including those that impact Bulgaria, Georgia, Romania, Russia, Turkey, Ukraine, and the Black Sea. There is also a discussion of environmental issues affecting the 
Caspian Sea: oil pollution, waste discharges, sea rise, environmental legislation, and outlook for 21 st century.

Key words: Azerbaijan, Bulgaria, Kazakhstan, Romania, Russia, Turkey, Ukraine, Black Sea, Caspian Sea; oil/natural gas, energy, environment, institutional development, international agreements; Energy Information Administration, U.S. government

\section{Environmental and Societal Impacts Group (ESIG)}

http://www.esig.ucar.edu/

September 2000. 1 page (home page). Links (to news articles, audio programs), frequently updated

ESIG studies environmental change to better understand the impacts associated with the complex relationship of the atmosphere, environment, and society. Its database includes many news articles, abstracts, research/outreach project descriptions, and additional links related to environmental issues in Central Asia, especially those associated with water resources (Black and Caspian Seas).

Key words: Black Sea, Caspian Sea; environment, GHG/GCC; ESIG, National Center for Atmospheric Research (USA)

\section{Developing the Implementation of the Black Sea Strategic Action Plan}

http://www.gefweb.com/wprogram/july96/blacksea/blacksea.htm

1996. 1 page. Links

This is the text of a Global Environment Facility proposal to facilitate the implementation of the Black Sea Strategic Action Plan.

Key words: Black Sea; environment, institutional development, international agreements; Global Environment Facility

\section{Black Sea Internet Node}

http://www.grid.unep.ch/bsein/

June 1999. 1 page (home page). Links

This site contains links to information on organizations and scientists studying the Black Sea; (inter)national research projects/programs (since 1990); cruise summary reports (since 1979); Black Sea bibliography (since 1974); acronyms and abbreviations; meta level information on environmental data for the Black Sea region; selected satellite images; and Black Sea Red Data 
Book (flora and fauna of region). It also contains recent data sets obtained in frameworks of

different international programs and copies of some historical data sets opened for public use.

Key words: Bulgaria, Georgia, Romania, Russia, Turkey, Ukraine, Black Sea; environment, international agreements; Black Sea Environment Programme

\section{Black Sea Transboundary Diagnostic Analysis}

http://www.grid.unep.ch/bsein/tda/index.htm

June 1996. 1 page (entry page). Narrative, tables, charts

The web version of the lengthy document is broken into sections accessed from the "Content" page. (Choose "Continue" on entry page.) This report represents the results of a systematic scientific analysis of the root causes of environmental degradation in the Black Sea. The document was prepared by an international team of specialists, most from institutions in the six coastal countries. The report contains information on the environmental problems and causes, major sources and reduction of pollution, fisheries, protection of endangered species and habitats, conservation area management, and sustainable development.

Key words: Bulgaria, Georgia, Romania, Russia, Turkey, Ukraine, Black Sea; environment, international agreements; Global Environmental, Facility Black Sea Environment Programme

\section{Conference Report: Black Sea Region: Priorities and Perspectives for the 21st Century}

http://www.irex.org/publications/policy-papers/black-sea.htm

1999. 5 pages. Narrative

Site contains discussion highlights and conclusion from a U.S. Information Agency (USIA)-funded conference held April 13-14, 1999, in Tbilisi, Georgia. Topics included economic development, trade incentives, legal framework, legal reform, and ecology.

Key words: Black Sea area; economics, environment; International Research and Exchanges Board

\section{The Black Sea Economic Co-Operation and the EU}

http://www.mfa.gov.tr/grupa/percept/33/I3-6.htm

September-November 1996. 7 pages. Narrative

Article by Ercan Özer in Perceptions: Journal of International Affairs 1(3), Center for

Strategic Research, Ankara, Turkey, September-November 1997. The article argues that the 
European Union and the Black Sea Economic Cooperation can be mutually beneficial organizations and that there are many perspective avenues for cooperation, including the energy resources of the Black Sea area, economic reform, and ending the pollution of the Black Sea.

Key words: Bulgaria, Georgia, Romania, Russia, Turkey, Ukraine, Black Sea; economics, environment, international agreements; Center for Strategic Research

\section{Fluxes of Greenhouse Gases in the Northwestern Region of the Black Sea Coastal Zone_-Influence of the Danube River System}

http://www.nitg.tno.nl/eng/projects/3 danube/index.shtml

No date given. 1 page (first of 3 linked pages)

The site describes an ongoing project (in the second of three years) to measure greenhouse gases in natural sediments within the Danube Delta. The project aims to evaluate the contribution of gas expulsions from different parts of the delta; evaluate and model the effects of river channels and arms on gas production in shallow lakes; calculate total annual fluxes of $\mathrm{CO}_{2}, \mathrm{~N}_{2} \mathrm{O}$, and $\mathrm{CH}_{4}$ from the entire delta region; and to provide model input for predicting the changes in gas emissions due to changes in the delta morphology and ecology.

Key words: Bulgaria, Romania, Ukraine, Black Sea; GHG/GCC; Netherlands Institute of Applied Geoscience TNO-National Geological Survey

\section{Cooperative Monitoring and Its Role in Regional Security}

http//www.osti.gov/bridge/product.biblio.jsp?osti id=465860

March 1997. 1 page (abstract). Link to 64 pages of text (in Adobe PDF format)

This paper discusses the roles of cooperative monitoring systems in promoting regional collaboration on security agreements. Two examples where U.S. Department of Energy (DOE) technologies and technical expertise can make contributions are discussed: (1) nuclear transparency in Northeast Asia and (2) environmental restoration in the Black Sea. This is an example of information available through DOE's Information Bridge database (http//www.osti.gov/bridge).

Key words: Black Sea; environment; U.S. Department of Energy

\section{Turkey: Black Sea Pollution Depletes Fishing Stocks} http://www.rferl.org/nca/features/1998/11/F.RU.981103134427.html

November 1998. 2 pages Narrative 
Text of radio report by Jolyon Naegele discussing the pollution of the Black Sea. While much of the pollution comes from other countries, Turkey has been impacted by the severe depletion of the fishing stock. Some species have died off, and the stocks of other species have been greatly reduced.

Key words: Russia, Turkey, Black Sea; environment; Radio Free Europe-Radio Liberty

\section{United Nations Development Programme (UNDP) National Human Development Reports}

http://www.undp.org/hdro/table.htm

August 2000, updated frequently. 5 pages. Table of available reports, links

More than 100 countries have published National Human Development Reports with UNDP support. By providing comprehensive indicators, the reports help to monitor progress and setbacks in human development and poverty at the national-level. The annual summary report for 2000 is also available online at http://www.undp.org/hdr2000/english/HDR2000.html. The 2000 Human Development Report includes a summary of national indicators such as energy use, growing urbanization, profile of environmental degradation, and access to information and communications. Each report also focuses on a highly topical theme in the current development debate, providing path-breaking analysis and policy recommendations. Individual country reports for some years are available online.

Key words: Armenia, Azerbaijan, Bulgaria, Georgia, Kazakhstan, Romania, Russia, Turkey, Ukraine; energy, environment, GHG/GCC, economics; United Nations Development Programme

\section{S. D. VanDeveer, "Protecting Europe's Seas” \\ Environment (journal) \\ July/August 2000, pp. 10-26}

Highlights progress to date with cooperative international efforts to improve the environmental quality in Baltic, Black/Azov, Caspian, Mediterranean and North Seas. Describes obstacles and processes to organize knowledge and politics, facilitate technical cooperation, and build advisory institutions and consensus. Includes tables on international agreements and most serious environmental challenges (such as high pollutant concentrations and increasing nutrient loads in Black Sea). Concludes with three challenges (integrating pollution control and prevention; agreeing on natural resource use; making common policies work) and lessons [ongoing dialogue is essential; resources must be dedicated to implementation; and capacity building can work (HELCOM example)]. 
Key words: Black Sea, Caspian Sea; international agreements, institutional development, environment; Environment

\section{Black Sea: Voyage of Healing \\ Bullfrog Films, Oley, Penn. \\ 1998. 54-min. color video}

This video chronicles a symposium on the Black Sea in Crisis, held aboard a cruise ship as it visits the countries of Georgia, Russia, Ukraine, Romania, Bulgaria, and Turkey, in a circumnavigation of the sea. The symposium was convened by the ecumenical patriarch, Bartholomew of Constantinople, of the Eastern Orthodox Church, in hopes of finding solutions to the problems of the Black Sea region. The participants included environmentalists, scientists, writers, and religious thinkers.

Key words: Black Sea, Bulgaria, Georgia, Romania, Russia, Turkey, Ukraine; environment; Bullfrog Films

\section{Black Sea Energy Survey \\ International Energy Agency \\ June 2000. 256 pages}

This study of the Black Sea region as a whole looks at its energy needs and how future oil and gas transport in the region could develop. It reviews the energy policies and sectors of seven countries with diverse energy situations. Azerbaijan is a major oil producer and exporter; Armenia and Georgia are energy-poor; Bulgaria and Romania are EU accession candidates which must restructure their domestic oil and coal industries; Greece and Turkey are IEA member states. This study covers energy strategies, institutions, and restructuring, as well as recent and projected energy trends in these countries. The book analyzes the reforms that are still needed to attract significant investment, both in domestic energy projects and in regional energy trade. A table of contents, sample material, and ordering information are found at http://www.iea.org/pubs/studies/files/blacksea/index.htm .

Key words: Black Sea, Armenia, Azerbaijan, Bulgaria, Georgia, Romania, Turkey; energy, oil/natural gas, economics; International Energy Agency

Proceedings of the North Atlantic Treaty Organization (NATO) Advanced Research Workshop on Environmental Degradation of the Black Sea: Challenges and Remedies, Constanta, Romania, October 6-10, 1997

ISBN 0-7923-5675-6, Kluwer Academic Publishers 1999. 393 pages 
This publication includes over 20 papers presented at a 1997 NATO workshop in Constanta, Romania. Each scientific paper focused either on environmental degradation of the Black Sea or on summarizing achievements of existing international programs. Topics included recent field, laboratory, and modeling results. Scientists from leading research institutes around the Black Sea in addition to organizations such as the U.S. Navy and Woods Hole Oceanographic Institution, contributed papers.

Key words: Black Sea; environment; North Atlantic Treaty Organization

\section{CASPIAN SEA REGION}

\section{Water Features and Water Issues: Caspian Sea}

http://eol.jsc.nasa.gov/newsletter/html Mir/caspian.html

June 2000. 5 pages. Narrative, photographs

This site contains NASA-Mir photographs of the flooded coastal regions of the Caspian Sea. The Caspian sea level has been rapidly rising (about $1.5-2 \mathrm{~m}$ ) for the past several years. Coastal regions, including infrastructures supporting the large oil industry, have been flooded. One photograph shows the largest oil slick photographed from space, off the shore of Azerbaijan.

Key words: Caspian Sea, Azerbaijan; environment; Jet Propulsion Laboratory

\section{Caspian Sea, Iran, and Caviar}

http://www.american.edu/projects/mandala/TED/caspian.htm

1993. 4 pages. Narrative

This paper discusses the recent political and environmental impacts on the caviar market. While Russia and Iran have traditionally been large suppliers, the pollution and increase in water levels in the Caspian Sea have threatened the supply of sturgeon and caviar. Azerbaijan, Turkmenia, Kazakhstan and Russia signed an agreement in 1992 to form an organization to exploit the Caspian marine resources.

Key words: Russia, Caspian Sea; environment; American University 


\section{Caspian Oil and Political Implications}

http://www.american.edu/projects/mandala/TED/caspoil.htm

1998. 9 pages. Narrative

Although once thought minimal, Caspian oil reserves are now considered more plentiful than Persian Gulf oil. This paper discusses the various claims on Caspian oil, and the political complications of various pipeline routes from the area. Tensions between Armenia and Azerbaijan threaten the shortest route between Baku and Turkey. Once the oil reaches the Black Sea, the most viable option is to ship it through the Bosporus. This route, however, has environmental implications because there are frequent oil leaks from tankers working their way through the narrow straits

Key words: Armenia, Azerbaijan, Russia, Georgia, Turkey, Black Sea, Caspian Sea; oil/natural gas, environment; American University

\section{Kazakhstan and Oil}

http://www.american.edu/projects/mandala/TED/kazakh.htm

1995. 8 pages. Narrative

Kazakhstan has been active in recruiting and negotiating with oil companies to exploit its large oil reserves. Developing pipelines to transport the oil has many challenges. Threats to the environment include heavy tanker traffic through the Dardanelles Straits and flooding of the refineries due to the rise in the Caspian Sea.

Key words: Kazakhstan, Caspian Sea; oil/natural gas, environment; American University

\section{Caspian Environment Programme}

http://www.caspianenvironment.org/second.htm

2000. 1 page (home page). Links

The Caspian Environment Programme is a regional umbrella program established by the states bordering the Caspian Sea and aided by the international agencies. A 1998 concept paper (http://www.caspianenvironment.org/concept.htm) provides the basis for the program. Links are provided to current projects, technical publications, and other sites with data, projects, and supporting organizations.

Key words: Azerbaijan, Kazakhstan, Caspian Sea; environment, international agreements; Caspian Environmental Programme 


\section{OPET (Organizations for the Promotion of Energy Technologies) Home Page}

http://www.cordis.lu/opet/home.html

December 1999. 2 pages. Links to over 80 energy-related web sites worldwide

The OPET Network "aims to promote the results of new energy technologies and their introduction in society in order to improve energy efficiency and broaden the use of renewable energy sources." Links to related sites include European Commission projects, Energy/Environment Research Centers, Energy Trade Associations, publications, events, success stories, and directories. One FEMOPET project focused on the Black Sea Region from 1998 to 2000 (Bulgaria/Romania). This was followed by the Black Sea Region OPET Associate Project (2000-2002, Russia, Turkey, Ukraine). Both projects, in conjunction with the Black Sea Regional Energy Centre, aimed to promote innovative renewable and conservation energy technologies.

Key words: Armenia, Azerbaijan, Black Sea, Bulgaria, Caspian Sea, Romania, Russia, Turkey, Ukraine; energy, environment, oil/natural gas, GHG/GCC, economics, international agreements, institutional development; European Commission Thermie Program

\section{Country Brief: Caspian-Bosporus/Black Sea Issues}

http://www.eia.doe.gov/emeu/cabs/caspblk.html

June 2000. 3 pages. Narrative

Site summarizes issues and concerns about proposed increases in shipment of oil from the Caspian Sea area through the Black Sea and the Bosporus. Impacts on Turkey, Bulgaria, Croatia, Moldova, Romania, and Ukraine are identified.

Key words: Bulgaria, Romania, Turkey, Ukraine, Black Sea, Caspian Sea; environment, oil/natural gas; Energy Information Administration, U.S. government

\section{Country Brief: Caspian Sea Region}

http://www.eia.doe.gov/emeu/cabs/caspian.html

June 2000. 5 pages. Narrative, map, links to related sites

http://www.eia.doe.gov/emeu/cabs/caspfull.html approx 30-page, more detailed report, with tables

The site discusses the oil and gas reserves in the Caspian Sea regions, and issues and options for export routes, including those that impact Bulgaria, Georgia, Romania, Russia, Turkey, Ukraine, and the Black Sea. There is also a discussion of environmental issues affecting the Caspian Sea: oil pollution, waste discharges, sea rise, environmental legislation, and outlook for 21st century. 
Key words: Azerbaijan, Bulgaria, Kazakhstan, Romania, Russia, Turkey, Ukraine, Black Sea, Caspian Sea; oil/natural gas, energy, environment, institutional development, international agreements; Energy Information Administration, U.S. government

\section{OPET (Organizations for the Promotion of Energy Technologies) Home Page} http://www.cordis.lu/opet/home.html

December 1999. 2 pages. Links to over 80 energy-related web sites worldwide

The OPET Network "aims to promote the results of new energy technologies and their introduction in society in order to improve energy efficiency and broaden the use of renewable energy sources." Links to related sites include European Commission projects, Energy/Environment Research Centers, Energy Trade Associations, publications, events, success stories, and directories. One FEMOPET project focused on the Black Sea Region from 1998 to 2000 (Bulgaria/Romania). This was followed by the Black Sea Region OPET Associate Project (2000-2002, Russia, Turkey, Ukraine). Both projects, in conjunction with the Black Sea Regional Energy Centre, aimed to promote innovative renewable and conservation energy technologies.

Key words: Armenia, Azerbaijan, Black Sea, Bulgaria, Caspian Sea, Romania, Russia, Turkey, Ukraine; energy, environment, oil/natural gas, GHG/GCC, economics, international agreements, institutional development; European Commission Thermie Program

\section{Global Environmental Problems in the Caspian Region}

http://www.esig.ucar.edu/caspian/

May 1999. 20 pages. Narrative, maps, figures

This paper by Michael H. Glantz discusses the problems facing the Caspian (including pollution, fisheries, and sea level changes and their causes), legal aspects and proposals for partitioning seabed resources, geopolitics, pipeline proposals and several analogies of how similar conflicts have been addressed in other parts of the world (e.g., Aral Sea, Great Lakes).

Key words: Caspian Sea; environment, energy; National Center for Atmospheric Research

\section{Central Eurasian Water Crisis: Caspian, Aral, and Dead Seas}

http://www.esig.ucar.edu/water crisis.html

No date given. 1 page. Narrative

This site contains an abstract for Central Eurasian Water Crisis: Caspian, Aral, and Dead Seas, edited Iwao Kobori and Michael Glantz, a book published by the United Nations 
University Press in Tokyo. According to the abstract, "The circum-Caspian region is one of the richest on the globe with regard to oil and gas reserves. Its environmental problems (oil and waste pollution, desertification, the survival of the sturgeon, and the fluctuating sea level) will only serve to worsen other regional political problems, unless they are addressed in the near future. In fact, it may be that addressing environmental issues directly can lead to cooperation in other areas."

Key words: Caspian Sea; environment; United Nations University Press

\section{An Inland Sea Open Up to the World: The Caspian}

http://www.evans.washington.edu/faculty/cla/537 00/caspian.html

1998. 7 pages. Map, short narratives, and links

This site discusses the oil resources beneath the Caspian Sea and the possible impacts of retrieving those resources on the environment. The situation in the Caspian Sea is complicated first by the determination of whether it is really a small sea or a large saline lake. International law would apply to a sea, and the area could be divided into separate territories for each of the five surrounding countries. A lake might be managed as a common resource for the good of all the surrounding nations. The problems of environmental protection are discussed in terms of impact on Caspian sturgeon, politics, nongovernmental organizations, and international organizations. A link to the Rachel Neville's paper "Environmental Protection in the Caspian Sea: Policy Constraints and Prescriptions" is also provided.

Key words: Caspian Sea; environment, oil/natural gas, institutional development; Washington University

\section{State of the Biodiversity of the Republic of Kazakhstan}

http://www.grida.no/enrin/biodiv/biodiv/national/kazakh/nav/index.htm

2000. 1 page (contents). Links

This page contains links to sections of the biodiversity report for the Republic of Kazakhstan. Included in the report is a description of the threats to the Caspian Sea (http://www.grida.no/ enrin/htmls/kazahst/soe/soee/nav/water/caspian.htm), primarily the changes in water level and oil pollution.

Key words: Kazakhstan; environment, institutional development, international agreement; National Environmental Center for Sustainable Development of the Republic of Kazakhstan

\section{State of the Environment, Turkmenistan}


http://www.grida.no/enrin/htmls/turkmen/soe/indexen.htm

November 1998. 1 page (home page). Links.

This site covers environmental issues in Turkmenistan with chapters on air, water, soils, climate, biodiversity, mineral resources, wastes, ecological legislation, administration and regional problems. It includes specific chapters on the Caspian Sea and fishing (sturgeon) at http:/www.grida.no/enrin/htmls/turkmen/soe/htmeng/problems.htm\#kaspy and http://www.grida.no/enrin/htmls/turkmen/soe/htmeng/fish.htm, respectively.

Key words: Caspian Sea; environment, energy, institutional development; Ministry of the Use of the Natural Resources and Environmental Protection of Turkmenistan.

\section{Caspian Sea: Four Nations Pledge Cooperation on Energy} http://www.rferl.org/nca/features/2000/05/F.RU.000522131539.html

May 2000. 2 pages. Narrative

This is a Radio Free Europe/Radio Liberty report on a May 19, 2000, seminar on energy, transportation, and security, held in Washington. There was a panel discussion that included representatives of Azerbaijan, Georgia, Kazakhstan, and Russia on the problems of getting oil and gas from the Caspian Sea-primarily the high cost of building pipelines and keeping them safe. Resolution of the conflict between Armenia and Azerbaijan would remove a major impediment development of the Caspian Sea's energy resources.

Key words: Azerbaijan, Georgia, Kazakhstan, Russia, Caspian Sea; oil/natural gas; Radio Free Europe/Radio Liberty

\section{United Nations Development Programme (UNDP) National Human Development Reports \\ http://www.undp.org/hdro/table.htm}

August 2000, updated frequently. 5 pages. Table of available reports, links

More than 100 countries have published National Human Development Reports with UNDP support. By providing comprehensive indicators, the reports help to monitor progress and setbacks in human development and poverty at the national-level. The annual summary report for 2000 is also available online at http://www.undp.org/hdr2000/english/HDR2000.html. The 2000 Human Development Report includes a summary of national indicators such as energy use, growing urbanization, profile of environmental degradation, and access to information and communications. Each report also focuses on a highly topical theme in the current development debate, providing path-breaking analysis and policy recommendations. Individual country reports for some years are available online. 
Key words: Armenia, Azerbaijan, Bulgaria, Georgia, Kazakhstan, Romania, Russia, Turkey, Ukraine; energy, environment, GHG/GCC, economics; United Nations Development Programme

\section{R. Cullen, "The Caspian Sea"}

\section{National Geographic}

May 1999. Pages 2-35. Maps, photos, narrative.

"The Soviet Union's breakup left regional economies in tatters; it also spurred the biggest oil rush of the past quarter century." This article documents the social, economic, cultural and environmental issues affecting the countries surrounding the Caspian, and its natural resources. Regional maps and keys depict such factors as income level, gas and oil reserves, landscapes, ethnolinguistic groups, oil/gas pipelines, sturgeon catch, etc.

Key words: Azerbaijan, Kazakhstan, Russia, Caspian Sea; energy, environment, economics, oil/natural gas; National Geographic Society.

\section{S. D. VanDeveer, "Protecting Europe's Seas" \\ Environment (journal) \\ July/August 2000, pp. 10-26}

Highlights progress to date with cooperative international efforts to improve the environmental quality in Baltic, Black/Azov, Caspian, Mediterranean and North Seas. Describes obstacles and processes to organize knowledge and politics, facilitate technical cooperation, and build advisory institutions and consensus. Includes tables on international agreements and most serious environmental challenges (such as high pollutant concentrations and increasing nutrient loads in Black Sea). Concludes with three challenges (integrating pollution control and prevention; agreeing on natural resource use; making common policies work) and lessons [ongoing dialogue is essential; resources must be dedicated to implementation; and capacity building can work (HELCOM example)].

Key words: Black Sea, Caspian Sea; international agreements, institutional development, environment; Environment 


\section{Caspian Oil and Gas: The Supply Potential of Central Asia and Transcaucasia}

International Energy Agency

May 1998. 297 pages

The Caspian region has the potential to become a significant producer and exporter of oil and gas. This comprehensive study provides data on, detailed descriptions of, and analysis of the oil and gas sectors of Azerbaijan, Kazakstan, Turkmenistan and Uzbekistan. It looks at the potential for oil and gas production and exports and points out technical, legal, financial, and other barriers to fulfilling this potential. The report also examines oil and gas pipeline routes, export markets, investment frameworks and major investment projects under way and planned. A table of contents, sample content, and ordering information can be found at http://www.iea.org/pubs/studies/files/caspian/index.htm .

Key words: Caspian Sea, Azerbaijan, Kazakhstan; energy, oil/natural gas, economics; International Energy Agency 